\title{
AVALIAÇÃO "IN VITRO" DO SELAMENTO APICAL DOS CANAIS RADICULARES EM FUNÇÃO DE DIFERENTES TÉCNICAS DE OBTURAÇÃO
}

\section{VIVIANE HAIUB BROSCO}

\begin{abstract}
Dissertação apresentada à Faculdade de Odontologia de Bauru da Universidade de São Paulo, como parte dos requisitos para obtenção do título de Mestre em Odontologia, área de Endodontia.
\end{abstract}

(Edição Revisada)

Bauru

2002 


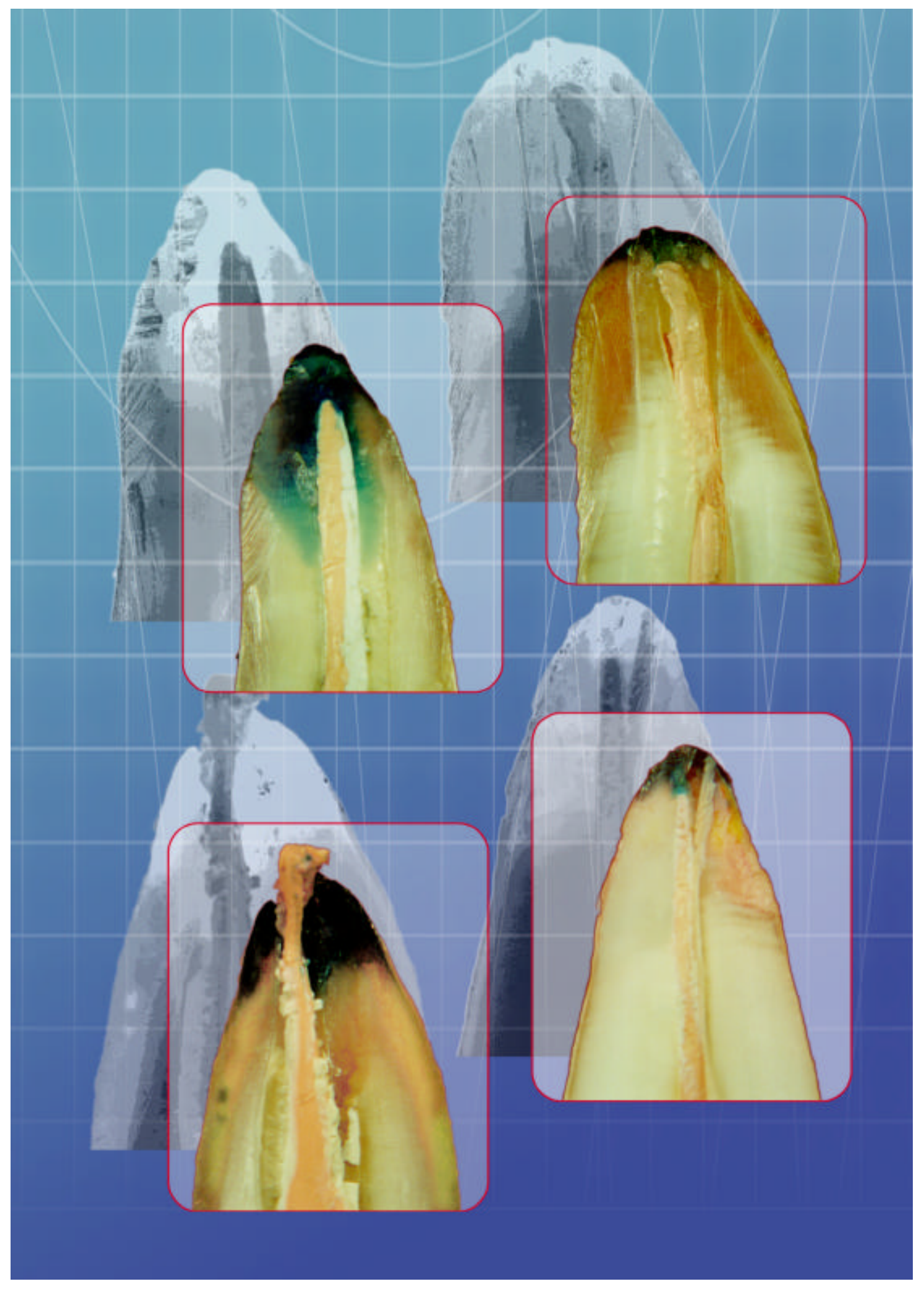




\title{
AVALIAÇÃO “IN VITRO” DO SELAMENTO APICAL DOS CANAIS RADICULARES EM FUNÇÃO DE DIFERENTES TÉCNICAS DE OBTURAÇÃO
}

\author{
VIVIANE HAIUB BROSCO
}

Dissertação apresentada à Faculdade de Odontologia de Bauru da Universidade de São Paulo, como parte dos requisitos para obtenção do título de Mestre em Odontologia, área de Endodontia.

Orientador: Prof. Dr. Norberti Bernardineli

(Edição Revisada)

Bauru

2002 
Brosco, Viviane Haiub

B792a Avaliação "in vitro" do selamento apical dos canais radiculares em função de diferentes técnicas de obturação. -- Bauru, 2002.

xvi, 136p. : il.; $30 \mathrm{~cm}$.

Dissertação (Mestrado) -- Faculdade de Odontologia de Bauru. Universidade de São Paulo.

Orientador: Prof. Dr. Norberti Bernardineli

Autorizo, exclusivamente para fins acadêmicos e científicos, a reprodução total ou parcial desta dissertação por processos fotocopiadores e outros meios eletrônicos.

Assinatura:

Data:

Data de aprovação pelo comitê de Ética em Pesquisa da FOB: 28 de junho de 2001. Protocolo de pesquisa ํo 147/00 


\section{DADOS CURRICULARES}

\section{Viviane Haiub Brosco}

Nascimento

Filiação

1992-1995

1996

1996-1998

$1998-2000$

2000-2002

Associações

23 de outubro de 1974

Bauru - SP

Wantuir Brosco e

Wadet Haiub Brosco

Curso de Odontologia na Universidade do Sagrado Coração - Bauru - SP

Curso de Aperfeiçoamento em Endodontia no HRAC - USP

Curso de Especialização em Endodontia no HRAC - USP

Curso de Especialização em Dentística no HRAC - USP

Curso de Pós-Graduação em Endodontia, em nível de Mestrado, na Faculdade de Odontologia de Bauru - USP

CROSP - Conselho Regional de Odontologia de São Paulo APCD - Associação Paulista de Cirurgiões Dentistas 


\section{Agradecimentos Especiais}

\section{A Deus,}

por me iluminar e me dar forças para concluir este trabalho.

\section{Aos meus pais Wantuir e Wadet,}

que sempre me incentivaram para que eu pudesse conquistar meus objetivos.

Vocês são meu ponto de referência; meu maior exemplo de amor, carinho, simplicidade e honestidade.

Tudo o que tenho hoje devo, exclusivamente, a vocês.

Tenho orgulho em ter pais tão maravilhosos!

A toda minha família, em especial aos meus irmãos Willian, Waldir e Walquíria e aos meus sobrinhos,

por estarem sempre presentes na minha vida e fazerem parte da minha história. Vocês moram no meu coração.

Ao meu namorado Fábio,

pelo carinho e amor que você me transmite diariamente, mesmo a distância. 
Ao meu orientador Prof. Dr. Norberti Bernardineli,

“O aprendizado nunca termina.

Não existe parte da vida que não contenha lições.

Se você está vivo, há lições para aprender."

(Anônimo)

Por me ajudar a concretizar mais essa "lição da minha vida" através de uma orientação precisa e minuciosa;

Pelos ensinamentos, pela paciência, respeito, confiança e, principalmente, pela grande amizade durante a nossa convivência;

Meu muito obrigada

Aos Professores do Departamento de Endodontia da FOB, Clóvis Monteiro Bramante, Norberti Bernardineli, Ivaldo Gomes de Moraes, Roberto Brandão Garcia e Alceu Berbert agradeço pela oportunidade de realizar o meu mestrado e pelo carinho com que vocês sempre me receberam e me ensinaram.

Ao professor Ivaldo, a quem muito admiro pela sua simplicidade, competência e maneira especial de tratar a todos, fazendo com que seus alunos se tornem seus amigos. Agradeço pelas valiosas contribuições na realização desta pesquisa. 
Aos amigos de curso de pós-graduação: Silvana, Graziela, José Francisco, Victor Hugo, Ulisses, Sônia, Guilherme e Juan;

Aos amigos do curso de Doutorado: Patrícia, Flaviana, Luciana, Christian, Carlos Herrero, Carlos Henrique, Fabiana, Sérgio e Vânia;

Aos amigos do "mestrado novo" ou 2001: Fernanda, Maristela, Giovana, Leandro, Everdan, Jazzmina, Renato, Rodrigo e Sérgio;

Agradeço pela amizade e por todos os momentos que juntos compartilhamos.

À Graziela e Silvana que, muito mais do que colegas de curso, se tornaram para mim verdadeiras amigas, compartilhando momentos bons e ruins, os quais, com certeza, serão inesquecíveis.

"Amigo é coisa pra se guardar do lado esquerdo do peito, dentro do coração".

(Milton Nascimento) 


\section{Agradeço também}

Ao HRAC "Centrinho" onde, além de ter a oportunidade de me aperfeiçoar tecnicamente, aprendi a considerar o aspecto "humano" do paciente durante o tratamento.

Aos setores de Endodontia e Dentística do Centrinho, em especial ao Kenji, Laerte, Renata, Maria Teresa, Lílian e Edninha.

Ao Prof. Dr. Heli Benedito Brosco, diretor da área Odontológica do Centrinho.

Aos funcionários do departamento de Endodontia da FOB, Edimauro, Suely, Patrícia e Neide, pela convivência agradável e pelo carinho.

À Tânia, do departamento de Histologia, e ao Kazuo, do departamento de informática da FOB, pela colaboração na obtenção das fotografias utilizadas para ilustrar este trabalho.

Ao Prof. Dr. José Roberto Pereira Lauris, pela análise estatística dos resultados.

À Valéria Cristina Trindade Ferraz, pela correção das referências bibliográficas desse trabalho.

À professora Eloísa, pela correção ortográfica. 
À Gisele, pela confecção do Abstract.

À Faculdade de Odontologia de Bauru (FOB), através da Diretora Profa. Dra. Maria Fidela de Lima Navarro e do corpo docente.

À Comissão de Pós-Graduação da FOB, na pessoa do Prof. Dr. Luiz Fernando Pergoraro.

Aos funcionários da Biblioteca da FOB, Ademir, César, Cybelle, Rita, Valéria e Vera.

Aos funcionários da reprografia, Salvador, Paula, Marquinhos, Lígia e Vanessa.

Aos funcionários da Pós-Graduação da FOB, Aurélio e Giane.

Aos funcionários do departamento de Dentística da FOB, em especial ao Nelson.

À FAPESP, pela concessão da bolsa de estudo. 


\section{SUMÁRIO}

LISTA DE FIGURAS $x i$

LISTA DE TABELAS xiv

LISTA DE ABREVIATURAS E SÍMBOLOS $x V$

RESUMO $x v i$

1 - INTRODUÇÃO 1

2 - REVISÃO DE LITERATURA 6

2.1 - Guta-percha 7

2.1.1 - Histórico 7

2.1.2 - Características 8

2.2 - Técnicas de obturação 13

2.2.1 - Técnica da Condensação Lateral 13

2.2.1.1 - Considerações gerais

2.2.1.2 - Infiltração apical e outras características da obturação realizada pela técnica da Condensação Lateral 15

2.2.2 - Técnica da Onda Contínua de Condensação 16

2.2.2.1 - Histórico 16

2.2.2.2 - System B 18

2.2.2.3 - Infiltração apical e outras características da obturação realizada com o System B

2.2.3 - Técnica da guta-percha termoplastificada injetável 24

2.2.3.1 - Histórico 24

2.2.3.2 - Sistema Ultrafil 26

2.2.3.3 - Infiltração apical e outras características da obturação realizada com o sistema Ultrafil

2.2.4 - Técnica da guta-percha plastificada termomecanicamente 42 2.2.4.1 - Histórico 42 
2.2.4.2 - Sistema JS Quick-Fill

2.2.4.3 - Infiltração apical e outras características da obturação realizada com o sistema JS Quick-Fill

2.2.5 - Técnica da guta-percha termoplastificada associada a um cone principal

2.2.5.1 - Histórico 45

2.2.5.2 - Sistema Microseal 46

2.2.5.3 - Infiltração apical e outras características da obturação realizada com o sistema Microseal

2.3 - Técnicas de avaliação da infiltração apical 48

3 - PROPOSIÇÃO

4 - MATERIAL E MÉTODOS

4.1 - Sistemas de obturação utilizados 55

4.1.1 - System B 55

4.1.2 - Ultrafil 57

4.1.3 - JS Quick-Fill 59

4.1.4 - Microseal 60

4.2 - Metodologia 62

4.2.1 - Seleção dos dentes 62

4.2.2 - Preparo biomecânico dos canais radiculares 62

4.2.3 - Seleção do cone principal 63

4.2.4 - Impermeabilização dos dentes 64

4.2.5 - Aplicação do EDTA e secagem dos canais radiculares 66

4.2.6 - Obturação dos canais radiculares 66

4.2.6.1 - Técnica da Condensação Lateral 68

4.2.6.2 - Técnica da Onda Contínua de Condensação realizada com o System B 68 
4.2.6.3 - Técnica da guta-percha termoplastificada injetável realizada com o sistema Ultrafil

4.2.6.4 - Técnica da guta-percha termoplastificada mecanicamente realizada com o sistema JS Quick-Fill

4.2.6.5 - Técnica da guta-percha termoplastificada associada a um cone principal realizada com o sistema Microseal

4.2.7 - Selamento provisório

4.2.8 - Imersão dos dentes no corante e seccionamento longitudinal 73

4.2.9 - Avaliação da infiltração apical 74

5 - RESULTADOS 75

5.1 - Técnica da Condensação Lateral 79

5.2 - System B 80

5.3 - Sistema Ultrafil 82

5.4 - Sistema JS Quick-Fill 83

5.5 - Sistema Microseal 85

6 - DISCUSSÃO 87

6.1 - Discussão da metodologia 88

6.2 - Discussão dos resultados 100

7 - CONCLUSÕES

REFERÊNCIAS BIBLIOGRÁFICAS

ABSTRACT 133 APÊNDICE 135 


\section{LISTA DE FIGURAS}

FIGURA 1 - Monômero isopreno da borracha natural (cis-poliisopreno) e da guta-percha (trans-poliisopreno)

FIGURA 2 - Aparelho System B - A- botão "liga/desliga"; B- botão "potência"; C- botão "controle de temperatura"; D- visor de temperatura; Ebotão "modo de operação"; F- luz de aquecimento e G"controle de pé"

FIGURA 3 - A- Condensador FM do System B; B- Cone Autofit FM; C- Cone Autofit FM inserido na régua calibradora

FIGURA 4 - Aquecedor do sistema Ultrafil. A- Vista frontal; B- Vista superior

FIGURA 5 - Componentes do sistema Ultrafil. A- seringa; B- cânulas azuis, preenchidas por guta-percha de consistência firme

FIGURA 6 - A e B - Compactadores do sistema JS Quick-Fill, ㄲo 15 ao 30, de 21 milímetros de comprimento

FIGURA 7 - Componentes do sistema Microseal. A- aquecedor e seringa Microflow; B- cone principal Microflow no 40; C- cartuchos de guta-percha Microflow

FIGURA 8 - A e B - Compactadores de níquel-titânio do sistema Microseal

FIGURA 9 - Dentes impermeabilizados, fixados em uma lâmina de 
FIGURA 10 - Incisivo inferior preso na morsa

FIGURA 11 - Gráfico da infiltração apical média (em milímetros) dos grupos avaliados

FIGURA 12 - Gráfico da distribuição dos dentes do grupo da Condensação Lateral em função da extensão em que as infiltrações ocorreram

FIGURA 13 - Infiltração apical do corante azul de metileno observada nos espécimes do grupo da Condensação Lateral

FIGURA 14 - Gráfico da distribuição dos dentes do grupo do System B em função da extensão em que as infiltrações ocorreram

FIGURA 15 - Infiltração apical do corante azul de metileno observada nos espécimes do grupo do System B

FIGURA 16 - Gráfico da distribuição dos dentes do grupo do sistema Ultrafil em função da extensão em que as infiltrações ocorreram

FIGURA 17 - Infiltração apical do corante azul de metileno observada nos espécimes do grupo do sistema Ultrafil

FIGURA 18 - Gráfico da distribuição dos dentes do grupo do sistema JS Quick-Fill em função da extensão em que as infiltrações ocorreram

FIGURA 19 - Infiltração apical do corante azul de metileno observada nos 
espécimes do grupo do sistema JS Quick-Fill

FIGURA 20 - Gráfico da distribuição dos dentes do grupo do sistema Microseal em função da extensão em que as infiltrações ocorreram

FIGURA 21 - Infiltração apical do corante azul de metileno observada nos espécimes do grupo do sistema Microseal 


\section{LISTA DE TABELAS}

TABELA 1 - Distribuição dos dentes de acordo com os grupos controles e experimentais

TABELA 2 - Infiltração apical (em milímetros) do corante azul de metileno nos dentes avaliados, segundo as técnicas obturadoras utilizadas

TABELA 3 - Valores médios (em milímetros) da infiltração apical do corante azul de metileno, $(\bar{X})$, desvio-padrão $(\mathrm{dp})$ e número de amostras (N) dos grupos avaliados

TABELA 4 - Comparação das médias de infiltração apical entre os grupos, pelo teste estatístico de Dunn, com nível de significância de $5 \%$ 


\section{LISTA DE ABREVIATURAS E SÍMBOLOS}

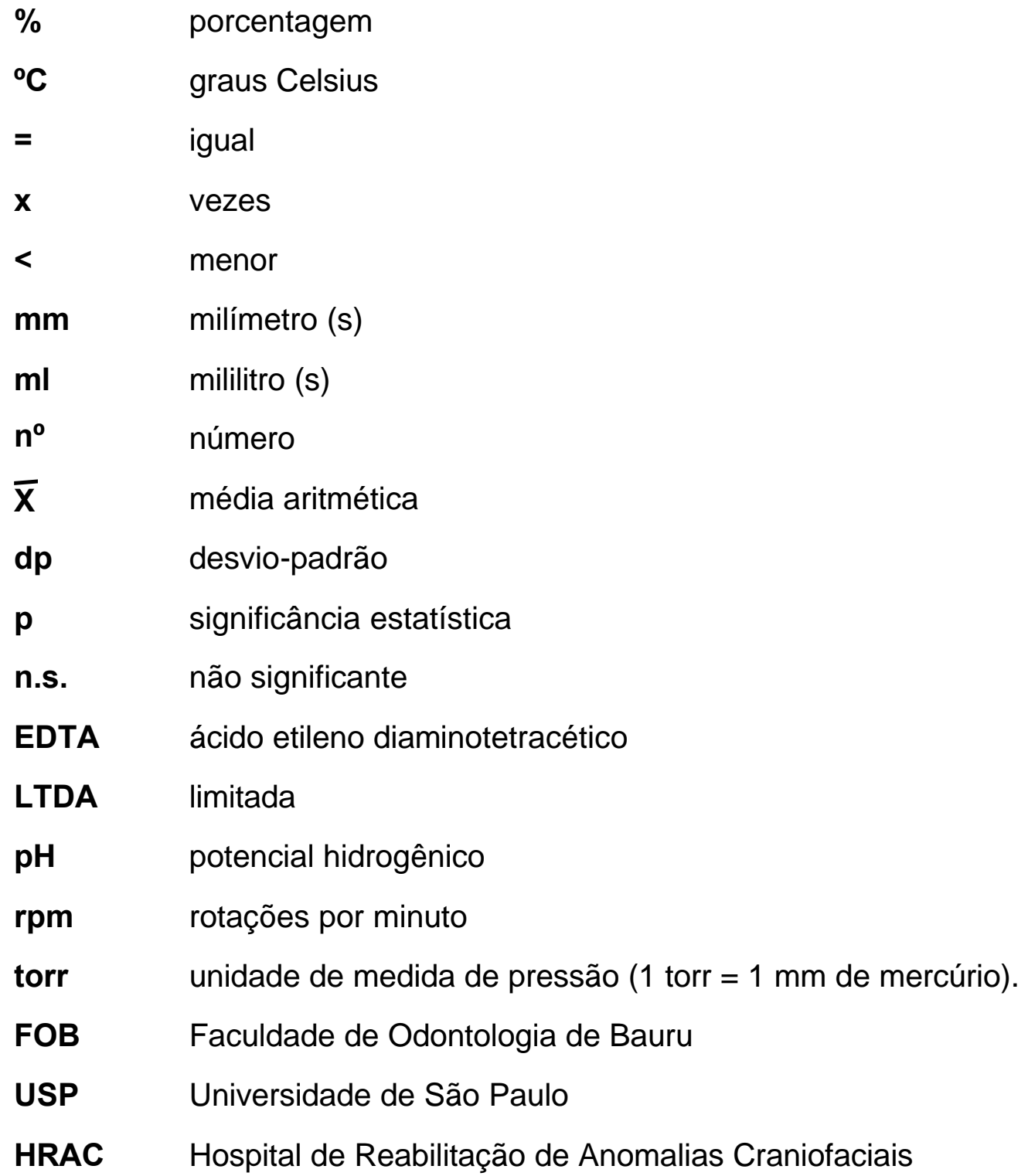




\section{RESUMO}

Este estudo teve como objetivo avaliar o selamento apical de canais radiculares obturados por diferentes técnicas. Cento e seis incisivos inferiores humanos tiveram seus canais instrumentados através da técnica escalonada regressiva. Após a instrumentação, cem dentes foram impermeabilizados nas superfícies externas da coroa e da raiz, exceto nas proximidades do forame apical, com uma camada de araldite e duas camadas de esmalte para unhas. Em seguida, foram divididos em cinco grupos de vinte elementos cada, de acordo com a técnica de obturação utilizada: 1. condensação lateral ativa realizada com lima tipo Kerr; 2. Onda Contínua de Condensação realizada com o System B; 3. guta-percha termoplastificada injetável realizada com o sistema Ultrafil; 4. guta-percha termoplastificada mecanicamente realizada com o sistema JS Quick-Fill; 5. gutapercha termoplastificada associada a um cone principal realizada com o sistema Microseal. Os seis dentes restantes foram utilizados como controles positivo e negativo. Após a obturação, as aberturas coronárias foram seladas e os dentes imersos em solução aquosa de azul de metileno a $2 \%$, durante setenta e duas horas, a $37^{\circ} \mathrm{C}$. A seguir, os dentes foram seccionados longitudinalmente e a infiltração apical avaliada em um estereomicroscópio. O sistema Microseal apresentou a melhor capacidade de selamento apical, seguido pelo System B, JS Quick-Fill, Ultrafil e pela técnica da condensação lateral. A análise estatística dos resultados demonstrou que: 1. o sistema Microseal apresentou selamento apical semelhante ao do System B e melhor que dos demais grupos; 2. o System B apresentou selamento apical melhor que o da técnica da Condensação Lateral e semelhante ao dos demais grupos; 3. os grupos da Condensação Lateral, Ultrafil e JS Quick-Fill, apresentaram capacidade de selamento semelhante. 


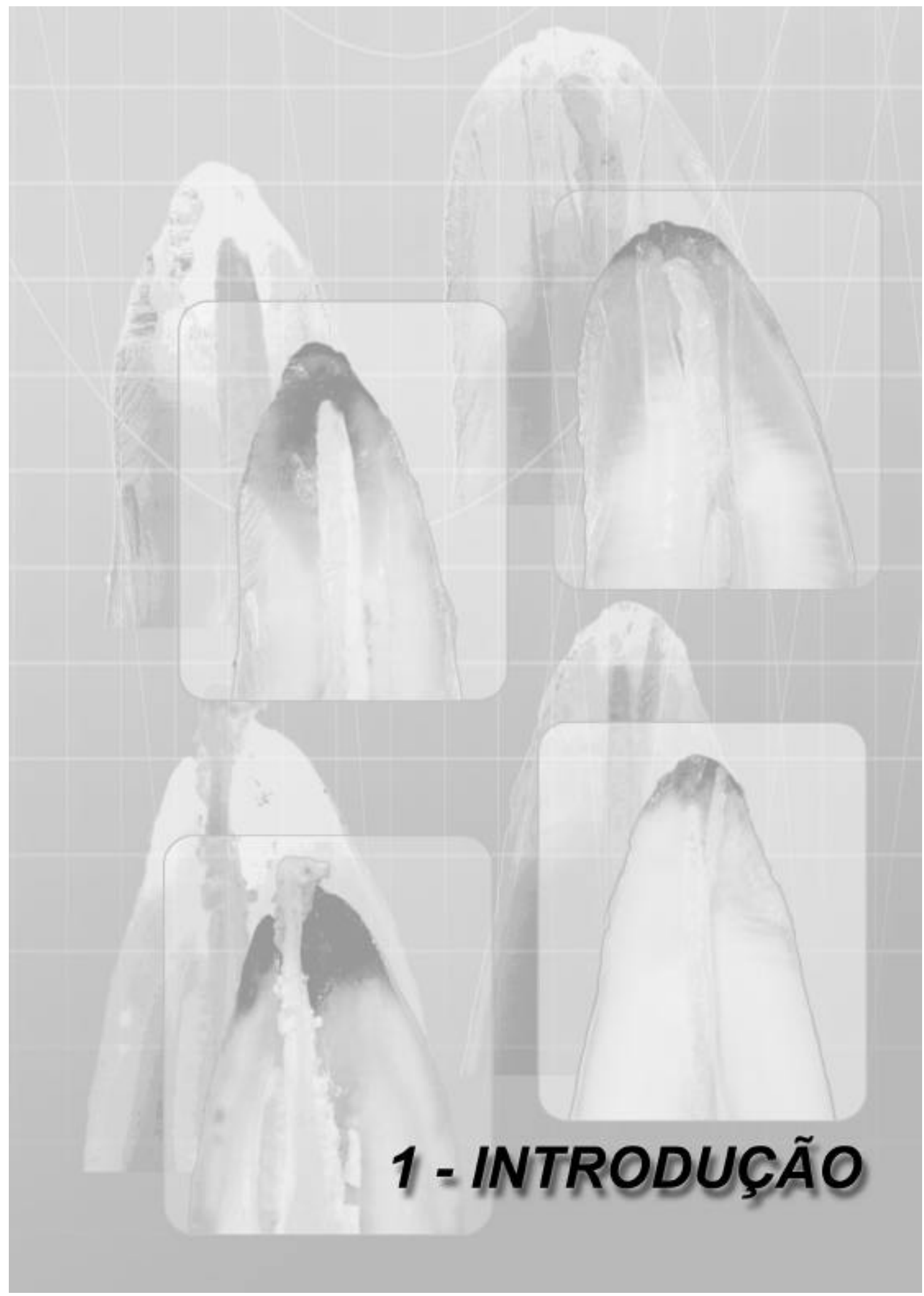




\section{I - I NTR ODUÇÃO}

O sucesso do tratamento endodôntico é fundamental para a reintegração fisiológica do dente ao sistema estomatognático e, para que isso ocorra, é necessária a realização adequada das suas diferentes etapas: correto diagnóstico, manutenção da cadeia asséptica, instrumentação eficiente, irrigação com soluções apropriadas ${ }^{93}$ e, finalmente, a obturação hermética e tridimensional do sistema de canais radiculares ${ }^{6}, 46,82,86,95,117$, no nível da junção dentinocementária $^{10,32,55,114 .}$

Apesar de todas as fases do tratamento endodôntico merecerem a mesma atenção por serem consideradas passos operatórios interdependentes $^{15,41,87}$, tende-se a dar uma maior ênfase à obturação, pois é ela que ocupará o lugar da polpa dentária e refletirá a qualidade do tratamento endodôntico realizado ${ }^{15,41}$.

INGLE et al. ${ }^{68}$, em 1994, relataram que aproximadamente $60 \%$ dos insucessos dos tratamentos endodônticos decorrem de uma obturação inadequada do canal radicular.

A dificuldade na obturação do sistema de canais radiculares pode ocorrer em virtude da complexidade da anatomia do mesmo ${ }^{36,75}$. Uma raiz, com um único forame apical, tem se mostrado uma exceção, em vez de uma regra ${ }^{36}$, e os canais laterais têm sido encontrados em cerca de $27 \%$ a $45 \%$ dos dentes ${ }^{117}$. As pesquisas, de um modo geral, também têm demonstrado a presença de múltiplas foraminas, deltas apicais e canais acessórios como componentes desse sistema ${ }^{1,24,}$ $36,48,49,110,117$. Como resultado, conseguir um selamento tridimensional torna-se bastante difícil ${ }^{1,110}$.

O selamento tridimensional do sistema de canais radiculares é de fundamental importância ${ }^{81}, 132,139$ pois, ao ocupar o espaço criado pela instrumentação, a obturação evita a infiltração do exsudato periapical para o interior do canal radicular ${ }^{61}$. Como conseqüência, inviabiliza a sobrevivência de microorganismos residuais após o preparo biomecânico ${ }^{79,131}$, evita a estagnação de 
líquidos $^{29,131}$ e oferece condições para que ocorra o reparo ${ }^{29,41,117,131}$, contribuindo, de maneira decisiva, para o sucesso da terapêutica endodôntica ${ }^{117,131,149}$.

A obturação adequada dos canais radiculares está intimamente relacionada às técnicas e aos materiais nela utilizados ${ }^{118}$. A maioria das técnicas, desde que corretamente empregadas, satisfazem o requisito de uma boa obturação e os materiais obturadores usados, apresentando propriedades físicas, químicas e biológicas satisfatórias, contribuem significativamente para o sucesso do tratamento realizado.

A obturação do canal radicular deve ser realizada no limite adequado $^{10,82}$, com materiais que promovam um selamento o mais hermético possível $^{10,24}$ e que não sejam irritantes aos tecidos periapicais ${ }^{15}, 17,29,87$. Radiograficamente, a obturação do canal deverá ser densa, sendo que obturações com limite apical aquém do desejável ou com deficiência de condensação devem ser evitadas $^{82}$.

O material obturador deverá apresentar as seguintes características: biocompatibilidade, estabilidade dimensional, radiopacidade, fácil manipulação, insolubilidade nos fluidos bucais e adaptabilidade às paredes do canal radicular $^{24,29,74,130,135}$.

As técnicas endodônticas, de um modo geral, utilizam para a obturação dos canais radiculares a guta-percha associada a um cimento obturador ${ }^{12}$, 86, 114, 122. A guta-percha é escolhida devido às suas propriedades físicas, mecânicas e biológicas ${ }^{114}$. Já o cimento deve ter a capacidade de se adaptar às irregularidades do canal $^{122}$ e proporcionar, associado à guta-percha, um bom selamento ${ }^{12}$. A obturação deverá apresentar o máximo de seu volume composto de guta-percha, com a mínima quantidade de cimento ${ }^{54}$.

Muitas técnicas de obturação têm sido propostas e todas elas apresentam vantagens e desvantagens ${ }^{114}$ quanto à sua aplicabilidade.

A condensação lateral a frio da guta-percha é a técnica de obturação mais utilizada na Endodontia ${ }^{1}$ 32, 46, 85, 110, 122, 130. Apresenta como vantagens facilidade de execução e melhor controle do limite da obturação ${ }^{74,85}$. Porém, pode consumir muito tempo e, freqüentemente, resultar em uma obturação 
não homogênea, constituída por cones envolvidos por cimento ${ }^{9,46,74,122,123}$ e com pobre adaptação às paredes e irregularidades do canal radicular ${ }^{6,16,32}$.

Inúmeras técnicas de obturação têm sido desenvolvidas ${ }^{120}$ com o intuito de melhorar o selamento apical dos canais radiculares ${ }^{6,34,45,103,108,110}$ e promover uma obturação tridimensional ${ }^{28,}{ }^{95}$. Dentre elas, destacam-se: condensação vertical da guta-percha aquecida, injeção de guta-percha termoplastificada, compactação termomecânica da guta-percha e guta-percha termoplastificada envolvendo um carregador ${ }^{1}$.

O System B é um aparelho gerador de calor que foi desenvolvido para ser utilizado na técnica da Onda Contínua de Condensação, a qual se originou a partir da técnica da condensação vertical da guta-percha aquecida. Esse aparelho, através dos seus condensadores, permite a plastificação e a condensação da guta-percha ${ }^{13,16}$, realizando a obturação do canal radicular $^{22,87,94,}$ ${ }^{129}$. Essa técnica resulta em uma obturação densa, com ótima adaptação às paredes do canal radicular ${ }^{82}$, além de um controle do limite apical da obturação ${ }^{22,23}$.

O sistema Ultrafil utiliza a guta-percha termoplastificada injetável em baixa temperatura, a qual é inserida no canal radicular com o auxílio de uma seringa. Essa técnica apresenta como vantagens rapidez de execução ${ }^{109}$ e selamento adequado das irregularidades do canal radicular ${ }^{31,45,97,98}$. Sua principal desvantagem se encontra na dificuldade de controle do limite apical da obturação ${ }^{87}$.

O sistema JS Quick-Fill emprega uma técnica de obturação termoplastificada mecanicamente. Nesse sistema, um compactador de titânio revestido por guta-percha é adaptado a um micromotor e inserido no canal radicular, promovendo a obturação do mesmo ${ }^{58,111}$. Apresenta como vantagens facilidade ${ }^{127} \mathrm{e}$ rapidez de execução da técnica ${ }^{58}$. A principal desvantagem do sistema JS Quick-Fill, como no sistema anterior, encontra-se na dificuldade de controle do limite apical da obturação $^{58}$.

O Microseal é um sistema de obturação misto, o qual utiliza um cone principal associado à guta-percha termoplastificada, que é levada ao canal radicular com um compactador de níquel-titânio e se funde ao cone principal, previamente assentado, formando uma massa homogênea. Esse sistema apresenta 
as seguintes vantagens: simplicidade, rapidez e eficiência da técnica e controle do limite apical da obturação $0^{81,131}$.

O advento dessas novas técnicas de obturação demonstra a preocupação dos pesquisadores na obtenção de um tratamento endodôntico com características cada vez mais favoráveis. Em virtude de o alto índice de insucessos do tratamento endodôntico ser atribuído à obturação insatisfatória do canal radicular, torna-se necessária a análise do selamento apical proporcionado por essas diferentes técnicas de obturação, já que o mesmo apresenta grande importância no sucesso do tratamento. 


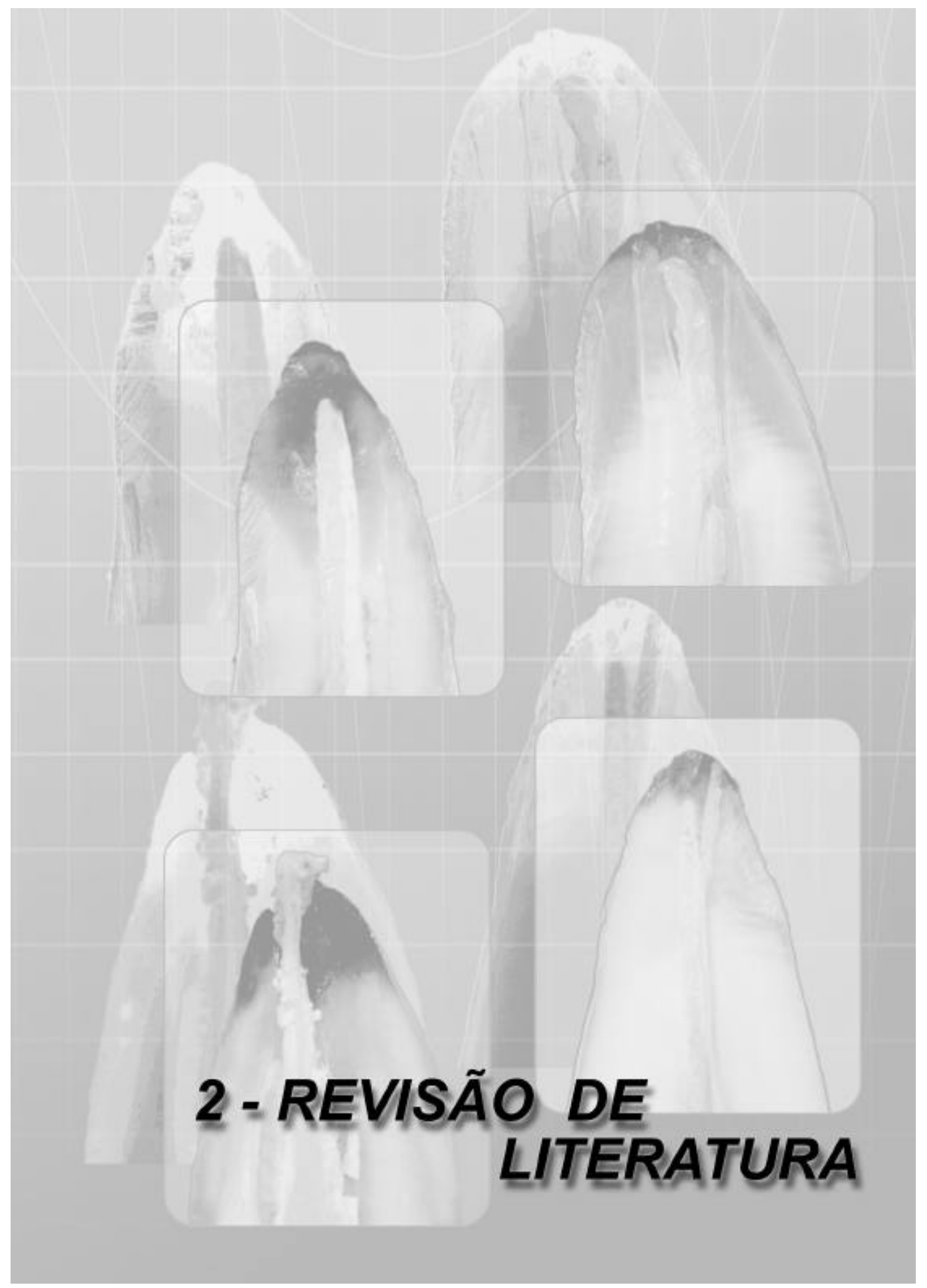




\section{2 - REVISÃO DE LITERATURA}

A necessidade $\mathrm{e} O$ ato de preencher $\mathrm{o}$ canal radicular já faz parte da rotina do cirurgião-dentista desde há muito tempo. FAUCHARD ${ }^{40}$, em 1745, já preconizava o uso de chumbo em folha para selar o espaço do canal radicular. Embora esse procedimento fosse realizado de forma empírica, dando margem a que diferentes autores adotassem um pitoresco arsenal endodôntico como madeira, piche, cera, bambu, entre outros ${ }^{29}$, a finalidade principal era vedar o canal radicular para mitigar a dor do paciente e devolver ao dente sua função ${ }^{41}$.

Atualmente, a guta-percha é o material mais utilizado para a obturação dos canais radiculares ${ }^{16,55,85,87,135}$ devido às suas propriedades físicas, químicas e biológicas, que tornam possível a sua utilização nas diferentes técnicas de obturação dos canais radiculares.

\section{1 - Guta-percha}

\subsection{1 - Histórico}

GOODMAN; SCHILDER; ALDRICH ${ }^{52}$, em 1974, relataram que a história primitiva da guta-percha é desconhecida e que os chineses comentam sobre seu uso em épocas remotas, antes mesmo de a civilização ocidental ter conhecimento da sua existência.

Segundo os autores ${ }^{52}$, há evidências de que a guta-percha se tornou conhecida na Europa através dos colecionadores de curiosidades da família Trandescants, em meados do século XVII. Esses colecionadores publicaram um livro de raridades citando o "mazer wood", que por mais de duzentos anos foi trazido à Inglaterra como uma curiosidade das regiões tropicais da Ásia, sem ter, no entanto, algum uso prático.

Na década de 1840, o "mazer wood" foi reintroduzido na Europa com o nome de guta-percha, a qual passou a ser aplicada nas artes, 
ciências e indústrias. Dois médicos de Singapura são pretendentes rivais à honra da sua reintrodução: Dr. José D' Almeida, que trouxe espécimes de guta-percha para Londres em 1843 e doou-os a um museu e Dr. William Montgomerie, que comunicou a descoberta da guta-percha ao Conselho Médico em Calcutá, em $1842{ }^{52}$.

Os autores ${ }^{52}$ relatam ainda que, a partir de 1848, a gutapercha teve um papel importante na eletricidade, sendo utilizada como isolante de cabos elétricos colocados dentro do mar. Isso foi possível graças à sua propriedade de permanecer inalterada em água fria, especialmente em água salgada.

A guta-percha, pela sua diversidade de uso, encantava a todos de tal forma que começaram a usá-la indiscriminadamente nas indústrias para fabricação de vários produtos como: cano, cortiça, revestimento de navios, instrumentos musicais, roupas, sombrinhas, instrumentos cirúrgicos, dentre outros. Seu uso pela indústria foi posteriormente abandonado pela propriedade que possui de se plastificar em temperaturas relativamente baixas ${ }^{52}$.

A guta-percha é conhecida na Odontologia há aproximadamente cento e cinqüenta $\operatorname{anos}^{52}$ e foi introduzida na Endodontia por Bowman, em $1867^{29,41,85,103 .}$

\subsection{2 - Características}

A guta-percha é uma substância vegetal extraída da árvore da família das sapotáceas, que tem suas origens na Indonésia, América do Sul e Malásia ${ }^{29}$. Na Malásia, a guta-percha significa "goma da Sumatra ${ }^{41}$ e, segundo LEONARDO; LEAL ${ }^{87}$, "gotah" significa goma e "pertja" significa árvore.

A guta-percha é um polímero orgânico natural de isopreno ${ }^{28}$, 90, 96, cuja molécula é formada por uma cadeia de átomos unidos por ligações covalentes. As ligações químicas ocorrem entre unidades pequenas e simples, formando longas cadeias ${ }^{90,146}$ de alto peso molecular ${ }^{29,146 .}$ 
Segundo GOODMAN; SCHILDER; ALDRICH ${ }^{52}$, os polímeros podem sofrer leves mudanças na disposição espacial ou nas ligações dos seus átomos. Esse processo é denominado isomerismo e resulta em diferenças marcantes nas propriedades mecânicas e térmicas do polímero.

O exemplo mais interessante de isomerismo é representado pela borracha natural e pela guta-percha. Ambas são polímeros de alto peso molecular e apresentam a mesma estrutura básica - monômero isopreno ${ }^{29,52}$.

O que irá diferenciar uma da outra será a localização do grupo $\mathrm{CH}_{2}$ no monômero isopreno. Na borracha natural, os grupos $\mathrm{CH}_{2}$ encontramse do mesmo lado da ligação dupla (cis-poliisopreno), enquanto na guta-percha os grupos $\mathrm{CH}_{2}$ estão em lados opostos da ligação dupla (trans-poliisopreno) ${ }^{29,}{ }^{2}$, como pode ser observado na Figura 1.<smiles>CC=C(C)C</smiles>

borracha natural<smiles>CC=C(C)C</smiles>

guta-percha

Fonte: STOCK $^{135}$, p.152.

FIGURA 1 - Monômero isopreno da borracha natural (cis-poliisopreno) e da gutapercha (trans-poliisopreno)

A forma "cis" (borracha natural) é retorcida e com alinhamento complexo, o que dá à borracha uma característica elástica. A forma "trans" (guta-percha) é linear e cristaliza-se mais rapidamente. Conseqüentemente, a guta-percha é mais dura, brilhante e menos elástica que a borracha natural ${ }^{29,52}$.

MARCIANO; MICHAILESCO; ABADIE ${ }^{90}$, em 1993, verificaram que o processo de industrialização não altera a configuração da gutapercha, sendo que a guta-percha industrializada apresenta a mesma configuração da guta-percha natural: isopreno trans 1-4. 
Observa-se, na clínica, que o volume da guta-percha é reduzido quando a mesma é condensada. Existiam dúvidas na literatura se a redução no volume da guta-percha seria devido à sua compressão ou não. Dessa forma, SCHILDER; GOODMAN; ALDRICH ${ }^{124}$, em 1974, realizaram um trabalho para verificar se a guta-percha apresentava compressibilidade. A compressão de um material é caracterizada pela redução do seu volume em decorrência da diminuição dos espaços entre as suas moléculas. Os autores ${ }^{124}$ verificaram que a redução no volume da guta-percha se dá pela consolidação e colapso de seus vazios e não pela diminuição dos espaços intermoleculares. Sendo assim, eles concluíram que durante os procedimentos clínicos a guta-percha sofre compactação e não compressão.

Em 1942, BUNN ${ }^{25}$ descobriu que a guta-percha pode existir em duas formas cristalinas, que foram denominadas de alfa e beta. As guta-perchas alfa e beta apresentam a mesma composição química ${ }^{28,52}$ e podem se converter uma na outra, diferindo apenas na localização da ligação simples e na distância intermolecular ${ }^{52}$.

Durante o processo de industrialização, o que irá determinar a forma alfa ou beta da guta-percha é a maneira pela qual a mesma é esfriada, já que isso controla a característica dos seus cristais, o tamanho da sua cadeia e o peso molecular. Em sua forma natural, na árvore, a guta-percha se encontra na forma alfa que, quando aquecida acima de $65^{\circ} \mathrm{C}$, se transforma em uma forma amorfa, amolecida. Se esse material amorfo for esfriado lentamente $\left(0,5^{\circ} \mathrm{C}\right.$ ou menos por hora) ele se cristalizará na forma alfa novamente. No entanto, se for esfriado rapidamente, como de rotina, cristalizar-se-á na forma beta ${ }^{29,30,52,90 .}$

WEATHERS JUNIOR ${ }^{146}$, em 1991, relatou que e o peso molecular e o tamanho da cadeia da guta-percha determinam suas propriedades físicas. A guta-percha natural encontra-se na fase alfa e é dura e quebradiça. Os fabricantes, através do procedimento de moagem ou do tratamento térmico, quebram as longas cadeias da guta-percha em pequenas cadeias, conferindo ao 
material a propriedade de flexibilidade. A guta-percha, após esse processamento, encontra-se na fase beta.

O autor ${ }^{146}$ ainda mencionou que muitos produtos atualmente disponíveis no mercado apresentam a guta-percha com peso molecular reduzido, o que confere à mesma as características de fluidez, escoamento, menor temperatura de plastificação e adesividade. A maior adesividade se dá pela presença dos radicais livres, provenientes das cadeias quebradas da guta-percha, os quais procuram se unir a "alguma coisa". O que importa, segundo o autor ${ }^{146}$, é o peso molecular da guta-percha e não se a mesma é alfa ou beta.

A guta-percha, como vimos, quando submetida ao calor, apresenta mudanças na sua fase. SCHILDER; GOODMAN; ALDRICH ${ }^{125}$, em 1974, verificaram as temperaturas em que ocorrem as transformações nos cristais de gutapercha quando ela é submetida ao calor. A guta-percha beta, quando aquecida na temperatura entre 42 a $49^{\circ} \mathrm{C}$, se transforma em alfa e, ao atingir entre 53 a $59^{\circ} \mathrm{C}$, se transforma em amorfa. Essas temperaturas estão de acordo com os estudos de BLUM; PARAHY; MACHTOU ${ }^{12}$, em 1997. Segundo GOODMAN; SCHILDER; $\mathrm{ALDRICH}^{52}$, em 1974, a temperatura em que a guta-percha apresenta mudança de fase é influenciada pelo grau de purificação da amostra, peso e distribuição molecular, porcentagem de cristalização e pelo processo de industrialização.

Segundo COMBE; COHEN; CUMMINGS ${ }^{30}$, em 2001, a gutapercha beta, quando aquecida, apresenta dois picos de temperatura (o primeiro entre 42 a $49^{\circ} \mathrm{C}$ e o segundo entre 53 a $59^{\circ} \mathrm{C}$ ), enquanto a guta-percha alfa apresenta apenas um pico. Baseados nesses dados, verificaram diferentes marcas comerciais de guta-percha para avaliarem se as mesmas eram do tipo alfa ou beta. Os autores constataram que a guta-percha dos sistemas Ultrafil e Thermafil é do tipo alfa (apresentou apenas um pico de temperatura), enquanto a guta-percha dos demais sistemas avaliados como Microseal, Multiphase, Sucessfil e Obtura é do tipo beta (apresentou dois picos de temperatura). 
A temperatura também afeta radicalmente a disposição dos polímeros lineares. Em baixas temperaturas, a guta-percha é rígida, com as suas cadeias mantidas em posição. Com o aumento da temperatura, a mesma torna-se amorfa, plastificada e as cadeias são vistas como espirais desordenadas, mudando continuamente de posição ${ }^{52}$.

GOODMAN; SCHILDER; ALDRICH ${ }^{53}$, em 1981, verificaram que a guta-percha, durante a sua condensação com instrumentos aquecidos no interior do canal radicular, atinge a temperatura de 45 a $80^{\circ} \mathrm{C}$. Também evidenciaram que ela é um condutor térmico restrito, já que os efeitos térmicos raramente se estenderam por mais que quatro a seis milímetros no interior do material. Sendo assim, a penetração do calor no interior da guta-percha é limitada durante a sua condensação.

As mudanças de fase da guta-percha também promovem alteração volumétrica da mesma. Quando aquecida da forma beta para a alfa ou amorfa se expande em virtude da excitação da sua molécula ${ }^{52}$. Após o seu esfriamento, retorna à fase beta e sofre uma contração, que geralmente é maior que a expansão ocorrida anteriormente. Isso significa que quando a guta-percha for aquecida acima de $42^{\circ} \mathrm{C}$ deverá ser realizada uma condensação para minimizar 0 problema da contração ${ }^{147,150}$ e prevenir o desenvolvimento de fendas ${ }^{135}$. Quanto maior for a temperatura de aquecimento, maior será a contração após o esfriamento $^{135}$.

A guta-percha, antes da adição de outros componentes, é um material de coloração branca ${ }^{147}$ ou cinza-avermelhada ${ }^{41}$. Com a adição de pigmentos, ela pode adquirir qualquer uma das cores do arco-íris ${ }^{147}$.

Os cones de guta-percha comercializados são compostos por: guta-percha, sulfato de bário, óxido de zinco, ceras e resinas. Esses componentes são combinados em diferentes quantidades dependendo da marca comercial $^{13}$. 
A guta-percha alfa apresenta como características: baixa temperatura de plastificação, boa adesividade, baixa viscosidade e excelente fluidez, enquanto a guta-percha beta apresenta alta temperatura de plastificação, alta viscosidade, baixa fluidez e não possuiu adesividade ${ }^{28,78,96}$.

A guta-percha tem sido empregada na obturação dos canais radiculares devido à sua biocompatibilidade, estabilidade dimensional, adaptação às paredes do canal radicular e facilidade de inserção. Além dessas vantagens, não promove alteração na coloração do dente e pode ser amolecida por solventes ou pelo calor ${ }^{13,41}$. Suas propriedades físicas e químicas possibilitam o seu emprego em diferentes técnicas de obturação $24,29,103,130$.

\section{2 - Técnicas de obturação}

A obturação é a fase final do tratamento endodôntico e apresenta grande importância, já que aproximadamente $60 \%$ dos insucessos do tratamento endodôntico são atribuídos à obturação insatisfatória dos canais radiculares ${ }^{33,68,97}$.

São inúmeras as técnicas existentes para a obturação dos canais radiculares, todas elas propondo como objetivo básico um selamento hermético e tridimensional do sistema de canais radiculares, utilizando um material não irritante aos tecidos periapicais ${ }^{87}$.

\subsection{1 - Técnica da Condensação Lateral}

\subsubsection{1 - Considerações gerais}

A condensação lateral, introduzida por CALLAHAN ${ }^{26}$, em 1914, tem sido a técnica de obturação mais utilizada na Endodontia ${ }^{23,41,135}$ devido à sua facilidade, preparo conservador do canal radicular ${ }^{32,54}$, simplicidade, eficiência ${ }^{23}$ e capacidade em controlar a extensão da obturação ${ }^{54,74,145}$. No entanto, essa 
técnica consome muito tempo ${ }^{74}$, não apresenta homogeneidade da massa obturadora $^{34}$ e os canais laterais e acessórios são dificilmente obturados ${ }^{23,45}$.

$\mathrm{Na}$ técnica da condensação lateral, utiliza-se um cone de guta-percha principal e vários cones de guta-percha secundários, interligados por um cimento endodôntico específico para essa finalidade ${ }^{18}$.

Alguns autores defendem que o cimento deve ser aplicado nas paredes do canal radicular antes da introdução do cone principal (técnica clássica), porém, isso provoca com freqüência extravasamento, que pode reduzir o número de sucesso do tratamento endodôntico ${ }^{102}$. Outros autores ${ }^{64}$ recomendam que o cimento deve ser levado juntamente com o cone de guta-percha principal, mantendo a extremidade do mesmo sem cimento (técnica biológica controlada), devido às propriedades possivelmente irritantes do cimento e à boa tolerância tecidual da guta-percha.

A técnica da condensação lateral pode ser realizada de maneira ativa, quando são utilizados espaçadores previamente à introdução dos cones secundários de guta-percha, ou de forma passiva quando não são utilizados espaçadores. Os espaçadores são instrumentos de parte ativa cônica e extremidade pontiaguda $^{29}$. São encontrados em diferentes conicidades e têm a função de abrir espaços para a colocação de cones secundários, lateralmente ao cone principal ${ }^{18}$.

Em 1972, BRAMANTE; BERBERT; PICCINO ${ }^{18}$ introduziram uma modificação na técnica da condensação lateral, com a substituição de espaçadores por limas tipo Kerr convencionais. Segundo os autores, essa técnica modificada apresenta as seguintes vantagens: pode ser realizada em canais de pequeno diâmetro, facilidade de aplicação, o espaço aberto durante a condensação apresenta uma forma semelhante à de um cone secundário, a lima pode ser removida sem alterar $\mathrm{o}$ assentamento dos cones colocados anteriormente $\mathrm{e}$ promove também uma leve condensação vertical. 
2.2.1.2 - Infiltração apical e outras características da obturação realizada pela técnica da Condensação Lateral

DOWN; INGLE ${ }^{35}$, em 1955, avaliaram o selamento apical de canais radiculares obturados pela técnica da condensação lateral. Os canais foram instrumentados e divididos em dois grupos, sendo que em um deles foram bem obturados, e no outro, mal obturados. Após a obturação, os dentes foram impermeabilizados e imersos em iodo radioativo $\left(1^{131}\right)$ durante cento e vinte horas. Após esse período, os dentes foram incluídos em blocos de resina e seccionados longitudinalmente. A infiltração apical foi avaliada através de auto-radiografias. Os canais bem obturados apresentaram menor infiltração de corante radioativo quando comparados aos canais mal obturados, evidenciando a importância da obturação adequada do canal radicular na obtenção de um bom selamento apical.

Em 1975, HOLLAND et al. ${ }^{64}$ estudaram o selamento apical de canais radiculares obturados pela técnica da condensação lateral, variando a forma de assentamento do cone principal - técnicas clássica ou biológica controlada. A aplicação do cimento nas paredes do canal antes da introdução do cone principal (técnica clássica) promoveu melhor selamento apical dos canais radiculares quando comparado ao cimento levado apenas nos cones de guta-percha (técnica biológica controlada).

ALLISON; MICHELICH; WALTON², em 1981, analisaram a influência da adaptação do cone principal e da profundidade da inserção do espaçador na infiltração apical de canais radiculares obturados pela técnica da condensação lateral. A adaptação do cone principal não teve um papel significativo na extensão da infiltração apical, ao contrário da profundidade da penetração do espaçador, cujo efeito foi muito importante. Nos canais em que foram utilizados espaçadores em pequena profundidade, observou-se que mais de $85 \%$ dos canais apresentavam infiltração apical extensa. Já nos canais onde foram utilizados espaçadores em maior profundidade, não foi observada infiltração apical extensa em nenhum espécime, independentemente da adaptação ou não do cone principal. Isso 
provavelmente ocorreu porque quando o espaçador foi introduzido de um a dois milímetros aquém do comprimento de trabalho, ele pode ter empurrado o cone e o cimento contra as paredes do canal, forçando-os apicalmente e melhorando o selamento apical.

MORAES; HOLLANDA ${ }^{102}$, em 1985, compararam a infiltração apical de canais radiculares obturados pelas técnicas da condensação lateral ativa e passiva e concluíram que a condensação lateral ativa mostrou menor infiltração apical que a passiva, porém sem diferença estatisticamente significante.

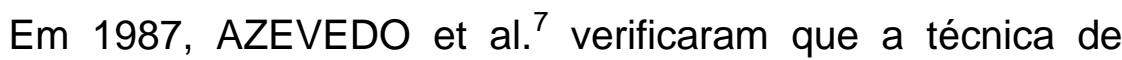
obturação da condensação lateral apresentou menor infiltração apical que a técnica do cone único, em canais instrumentados pela técnica clássica.

HOLLAND et al. ${ }^{66}$, em 1991, avaliaram a influência de alguns procedimentos clínicos na infiltração apical de canais obturados pela técnica da condensação lateral. Os autores verificaram que: a secagem do canal é preponderante para um bom selamento apical; o emprego do álcool para secar os canais radiculares não apresentou melhores resultados que o obtido pelos cones de papel; o emprego do EDTA e dos curativos de demora determinaram uma melhora no selamento apical.

\subsection{2 - Técnica da Onda Contínua de Condensação}

\subsubsection{1 - Histórico}

A técnica da Onda Contínua de Condensação se baseou na técnica da condensação vertical da guta-percha aquecida, preconizada por SCHILDER ${ }^{123}$, em 1967.

Nesta técnica ${ }^{123}$, após o assentamento do cone principal com cimento são utilizados espaçadores aquecidos na chama para aquecer e plastificar a guta-percha, para que ela seja, em seguida, condensada por instrumentos frios, 
realizando-se, assim, um processo de aquecimento e condensação contínuos. Inicialmente, o terço cervical é obturado e, em seguida, desobturado. Na seqüência, o mesmo procedimento é realizado no terço médio, até atingir cinco milímetros aquém do ápice. A quantidade do aquecimento do espaçador é que determinará se a guta-percha será aquecida ou removida. Após a obturação do terço apical, os terços médio e cervical são novamente obturados com pedaços de guta-percha aquecidos, que são condensados verticalmente. Uma nova onda de condensação é realizada na direção contrária (ápice-coroa) ao movimento inicial (coroa-ápice).

A técnica da condensação vertical da guta-percha aquecida promove uma obturação homogênea ${ }^{54}$, densa e tridimensional do sistema de canais radiculares, além de obturar a maioria dos canais acessórios e laterais com gutapercha ou cimento ${ }^{123}$ e ser dimensionalmente estável ${ }^{74}$.

A guta-percha aquecida apresenta ótima adaptação às irregularidades do canal ${ }^{88,145}$, formando um molde do seu interior ${ }^{23,123}$, inclusive com penetração de cimento e guta-percha nos túbulos dentinários ${ }^{88}$. Segundo BUCHANAN $^{23}$, casos tratados com essa técnica demonstram a complexidade surpreendente do sistema de canais radiculares.

A técnica de SCHILDER ${ }^{123}$, no entanto, apresenta algumas desvantagens: dificuldade de execução ${ }^{23}, 41,82,114$, consome grande quantidade de tempo $23,34,74,82,95,114,130$, dificuldade no controle da extensão do material obturador $^{23,145}$ e pode provocar fratura radicular se for usada uma força excessiva durante a condensação ${ }^{74}$. Outra grande desvantagem dessa técnica é o emprego de espaçadores aquecidos sobre a chama para plastificar o cone de guta-percha ${ }^{42,82}$, onde o calor não é controlado ${ }^{34,74,130 .}$

Com a finalidade de preservar os benefícios da técnica de Schilder e reduzir suas desvantagens, foram desenvolvidos condensadores

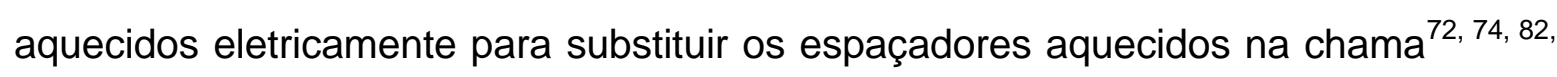
129. Dentre esses aparelhos, podemos citar o Touch'n heat e o System B, que são equipamentos específicos para essa finalidade. 


\subsubsection{2 - System B}

BUCHANAN $^{23}$, em 1996, baseado na técnica de SCHILDER $^{123}$, como descrito anteriormente, desenvolveu um novo método de condensação vertical da guta-percha aquecida, denominado Técnica da Onda Contínua de Condensação ${ }^{33,94}$, onde os espaçadores aquecidos na chama são substituídos por um aparelho aquecedor denominado System B ${ }^{33,95,104,129}$.

O System B, introduzido no mercado pela Analytic Tecnology ${ }^{137}$, é um aparelho gerador de calor, que funciona com baterias recarregáveis. É um dispositivo fácil, seguro e efetivo ${ }^{33,72, ~ 82, ~ 95, ~} 114$.

O System B permite realizar uma obturação mais rápida ${ }^{23,114}$ e monitorar a temperatura da ponta do seu condensador aquecido, distribuindo uma quantidade precisa de calor por um tempo indefinido ${ }^{13,22,23,82,86,104,130 .}$

Este sistema possui condensadores ("plugger") de diferentes diâmetros. O condensador, quando colocado no interior do canal, permite a plastificação e a condensação da guta-percha ${ }^{13}$, realizando, dessa forma, a técnica da Onda Contínua de Condensação ${ }^{22,87,94,129,136}$. A fase inicial dessa técnica, denominada "Downpack", objetiva o selamento do terço apical do canal radicular, enquanto o selamento dos demais terços é realizado com a fase "Backfill" 22, 23, 95.

As possibilidades que surgem com o avanço conceitual e técnico da Onda Contínua de Condensação são significantes ${ }^{23}$. Essa técnica, quando comparada à técnica de Schilder, apresenta como vantagens: maior rapide ${ }^{16}$, melhor controle do limite apical de obturação, pequeno número de instrumentos utilizados, menor probabilidade de deslocamento do cone principal e emprego de condensadores mais flexíveis e menos calibrosos, facilitando a condensação da obturação em canais curvos ${ }^{22,23}$. A Técnica da Onda Contínua de Condensação permite que seja realizada uma obturação tridimensional, sem o alargamento excessivo do terço cervical do canal, prevenindo possíveis perfurações ou fraturas radiculares ${ }^{23}$.

Apesar de desenvolvido para a técnica da condensação vertical da guta-percha aquecida, o System B pode ser utilizado também na técnica da condensação lateral aquecida, substituindo suas pontas pelas pontas do aparelho 
Touch'n heat (as quais se adaptam no System B) e utilizando temperaturas mais baixas (aproximadamente $100^{\circ} \mathrm{C}$ ), já que o objetivo nesse caso é apenas plastificar a guta-percha e não removê-la ${ }^{104}$.

O System B também apresentou bons resultados quando utilizado no retratamento de dentes obturados com o sistema Thermafil. Nesses casos, o System B teve a finalidade de amolecer a guta-percha que se encontrava ao redor do carregador do sistema Thermafil, para que o mesmo pudesse ser removido $^{148}$

2.2.2.3 - Infiltração apical e outras características da obturação realizada com o System B

Em 1997, MCROBERT; LUMLEY ${ }^{95}$ estudaram a infiltração coronária de canais radiculares que tiveram a obturação dos terços cervical e médio ("Backfill") realizada por três diferentes sistemas. Dez dentes foram obturados pela técnica da condensação lateral. Trinta dentes tiveram a obturação do terço apical realizada com o System B e foram divididos em três grupos, de acordo com 0 sistema de obturação utilizado na obturação "Backfill": Obtura II, System B e Alphaseal. As obturações "Backfill" realizadas pelo System B e Obtura II apresentaram menor infiltração coronária quando comparadas ao Alphaseal e à técnica da condensação lateral sendo, por essa razão, recomendadas pelos autores para serem utilizadas na rotina clínica.

LEE; VAN CURA; BEGOLE ${ }^{86}$, em 1998, analisaram a temperatura da superfície externa da raiz durante a obturação dos canais radiculares pela técnica da condensação vertical aquecida, usando três fontes de calor: chama, Touch'n heat e System B. O System B apresentou menor média de elevação da temperatura externa da raiz $\left(7^{\circ} \mathrm{C}\right)$, seguido pelo Touch'n heat $\left(9^{\circ} \mathrm{C}\right)$ e pela chama $\left(21^{\circ} \mathrm{C}\right)$, a qual apresentou o dobro da temperatura aceitável.

KYTRIDOU; GUTMANN; NUNN ${ }^{82}$, em 1999, compararam as obturações realizadas pelos sistemas Thermafil e System B em relação ao 
selamento apical, qualidade da obturação e extravasamento de material obturador. Cinqüenta e uma raízes mesiais de molares inferiores foram instrumentadas e irrigadas com EDTA para remoção da "smear layer". Em cada raiz, um dos canais foi obturado pelo sistema Thermafil e o outro pelo System B, utilizando-se o cimento Sealapex. Após a obturação, as raízes foram impermeabilizadas e divididas em três grupos: em dois grupos, as raízes foram colocadas em tinta nanquim e mantidas por vinte e quatro horas e dez dias, respectivamente; no terceiro grupo, as raízes foram mantidas em solução balanceada de Hank por sessenta e sete dias e logo após, colocadas em tinta nanquim por noventa horas. Os dentes foram desmineralizados e clareados e a infiltração apical foi avaliada com o auxílio de um estereomicroscópio. Nos períodos de vinte e quatro horas e dez dias, a infiltração apical foi semelhante para os dois sistemas - Thermafil e System B. Já aos sessenta e sete dias, o System B apresentou menor infiltração apical. O sistema Thermafil apresentou maior quantidade de material obturador extruído que o System B. Ambas as técnicas promoveram uma obturação densa e tridimensional e uma boa adaptação da gutapercha e do cimento às irregularidades do canal.

Em 1999, SILVER; LOVE; PURTON ${ }^{129}$ verificaram a qualidade da obturação de canais radiculares obturados pela técnica da condensação vertical aquecida, empregando diferentes fontes de calor: Touch'n heat e System B. Os canais foram confeccionados em blocos de resina e a qualidade da obturação analisada com o auxílio de um computador. No canal principal, ambos os grupos apresentaram uma obturação composta por uma grande porcentagem de guta-percha (superior a 90\%). A porcentagem de vazios na obturação apresentada pelas duas técnicas foi baixa. No System B, os vazios estavam presentes principalmente três milímetros aquém do ápice, provavelmente porque nesse nível se iniciou a fase "Backfill", podendo ocorrer uma plastificação ou adaptação inadequada do cone de guta-percha. A técnica da condensação vertical aquecida com o Touch'n heat mostrou maior quantidade de guta-percha nos canais laterais que a realizada com o System B. 
Nesse mesmo trabalho, SILVER; LOVE; PURTON ${ }^{129}$, em 1999, estudaram a elevação da temperatura na superfície externa da raiz durante a obturação dos canais radiculares, usando o Touch'n heat e o System B. O Touch'n heat promoveu uma elevação de temperatura acima de $10^{\circ} \mathrm{C}$. No System $\mathrm{B}$, a elevação de temperatura foi menor que $10^{\circ} \mathrm{C}$, que é o nível crítico, e o tempo da obturação foi menor quando comparado ao Touch'n heat.

DULAC et al. $^{36}$, em 1999, avaliaram a capacidade de preenchimento de canais laterais de seis técnicas de obturação. Os canais laterais foram confeccionados em blocos de resina, nos terços cervical, médio e apical. As técnicas analisadas foram: condensação lateral a frio, condensação lateral aquecida, condensação vertical aquecida, Obtura II, Thermafil e System B, com e sem cimento Roth 801. Todas as técnicas obturaram os canais laterais com cimento nos três terços avaliados. As técnicas da condensação vertical aquecida, Thermafil e System B promoveram uma melhor obturação dos canais laterais com guta-percha quando o cimento foi utilizado. No terço apical, as técnicas Thermafil e System B obturaram os canais laterais com guta-percha melhor que as demais técnicas. Com exceção da técnica da condensação lateral aquecida, as técnicas que utilizam guta-percha termoplastificada foram mais efetivas na obturação dos canais laterais com gutapercha.

Em 1999, FLOREN et al. $^{42}$ verificaram a influência da temperatura do condensador do System B na elevação da temperatura da superfície externa da raiz durante a obturação dos canais radiculares. Dez pares termelétricos foram colocados na superfície externa da raiz, nos comprimentos de um a dez milímetros aquém do ápice. O condensador do System B foi inserido no canal radicular três milímetros aquém do comprimento de trabalho, em diferentes temperaturas: 250, 300, 350, 400, 450, 500, 550 e $600^{\circ} \mathrm{C}$. A média da elevação de temperatura externa da raiz mais alta foi encontrada a cinco milímetros aquém do ápice $\left(10,62^{\circ} \mathrm{C}\right)$, seguida pela temperatura registrada a quatro milímetros aquém do ápice $\left(8,53^{\circ} \mathrm{C}\right)$. Nos demais níveis, a elevação média da temperatura externa da raiz foi menor que $6^{\circ} \mathrm{C}$. Os autores verificaram que o aumento da temperatura do 
condensador do System B não promoveu maior elevação da temperatura na superfície externa da raiz.

SMITH et al. ${ }^{130}$, em 2000, analisaram a influência da profundidade da aplicação do calor na qualidade da obturação de canais radiculares obturados com o System B. Foi utilizado um modelo de dente seccionado, no qual foram confeccionadas irregularidades previamente à obturação. Os canais foram obturados com o System B, com o condensador inserido a três, quatro, cinco e sete milímetros aquém do comprimento de trabalho. De um modo geral, quanto maior a profundidade de penetração da ponta do System B, melhor a adaptação da obturação às paredes do canal.

ROMERO; GREEN; WUCHERPFENNIG ${ }^{120}$, em 2000, avaliaram a temperatura da superfície externa da raiz durante a obturação do canal radicular com o System $B$. A média de elevação de temperatura foi de $1^{\circ} \mathrm{C}$ no ápice e ${ }^{\circ} \mathrm{C}$ a cinco milímetros aquém do mesmo. A temperatura encontrada pelos autores foi menor que a encontrada em outros estudos, provavelmente porque foi utilizado alginato ao redor do dente. O alginato contém grande quantidade de água, que ajuda a dissipar o calor, promovendo uma menor elevação da temperatura. Os autores verificaram que o calor transferido é influenciado pela espessura da raiz, sendo que raízes de menor espessura apresentaram maior elevação da temperatura na superfície externa durante a obturação do canal radicular.

Em 2001, POMMEL; CAMPS ${ }^{114}$ verificaram o selamento apical de canais radiculares obturados por diferentes técnicas. Oitenta dentes anteriores superiores foram instrumentados e divididos em grupos, de acordo com a técnica de obturação realizada: cone único, condensação lateral, condensação vertical, Thermafil e System B. O cimento obturador utilizado foi o Sealite. A infiltração apical foi avaliada através do método de filtração de fluido, após vinte e quatro horas e trinta dias da obturação dos canais. A técnica do cone único apresentou o pior selamento apical nos dois períodos avaliados. As demais técnicas não apresentaram diferença estatisticamente significante entre si no período de vinte 
e quatro horas. Após um mês, os sistemas Thermafil, System B e a técnica da condensação vertical apresentaram menor infiltração apical. Independentemente da técnica avaliada, a infiltração apical aumentou após um mês.

GOLDBERG; ARTAZA; SILVIO ${ }^{49}$, em 2001, compararam a capacidade de diferentes técnicas em obturar canais laterais confeccionados nos terços cervical, médio e apical de dentes unirradiculados. As técnicas avaliadas foram as seguintes: condensação lateral, Híbrida de Tagger, Ultrafil, Obtura II, Thermafil e System B + Obtura II. As técnicas Ultrafil, Thermafil e System B + Obtura II obturaram um grande número de canais laterais, diferindo-se estatisticamente das demais. Não houve diferença estatística significante na obturação dos canais laterais em relação à localização dos mesmos.

SWEATMAN; BAUMGARTNER; SAKAGUCHI ${ }^{136}$, em 2001, analisaram a alteração de temperatura nas superfícies interna e externa da raiz, durante a obturação do canal radicular com o System B (nas temperaturas de 200, 250 e $300^{\circ} \mathrm{C}$ ), Obtura e Ultra-som. A média de temperatura interna mais alta foi de $74^{\circ} \mathrm{C}, 2^{\circ} \mathrm{C}$ e $26^{\circ} \mathrm{C}$ para o System B, Ultra-som e Obtura, respectivamente. Em todos os sistemas, a temperatura externa da raiz se elevou abaixo de $10^{\circ} \mathrm{C}$, que é considerado o nível crítico.

Em 2001, SILVA NETO et al. ${ }^{128}$ estudaram o selamento apical de canais radiculares obturados por diferentes técnicas. Trinta e dois caninos foram instrumentados, impermeabilizados e irrigados com EDTA. Em seguida, os dentes foram divididos em dois grupos, de acordo com a técnica de obturação realizada: System B e Técnica de Tagger, utilizando-se o cimento Endomethasone. Após a obturação, os dentes foram imersos em corante azul de metileno a $2 \%$, durante setenta e duas horas, e seccionados longitudinalmente. A infiltração apical foi analisada com o auxílio de um microscópio. Os canais obturados com o System B apresentaram melhor selamento apical quando comparados aos obturados pela técnica de Tagger. 
BOWMAN; BAUMGARTNER ${ }^{16}$, em 2002, verificaram a capacidade de preenchimento de sulcos e depressões das obturações realizadas com o System B. Foi utilizado um modelo de dente seccionado, no qual foram confeccionados sulcos e depressões na raiz a um, três, cinco e sete milímetros aquém do comprimento de trabalho. $O$ terço apical do canal foi obturado com o System B, com o condensador inserido em diferentes profundidades: três, quatro e cinco milímetros aquém do comprimento de trabalho. Os demais terços foram obturados pelo sistema Obtura II. Como grupo controle, utilizou-se a técnica da condensação lateral. Após a obturação, as metades do dente foram separadas e a obturação fotografada. Na técnica da condensação lateral, em todos os níveis, não foi observada guta-percha nas depressões ou nos sulcos confeccionados na dentina; observou-se apenas a presença de cimento nesses locais. Os autores concluíram que quando o condensador do System B foi inserido a três milímetros aquém do comprimento de trabalho, promoveu melhor obturação com guta-percha das depressões e sulcos confeccionados no canal radicular.

Nesse mesmo ano de 2002, JACOBSON et al. ${ }^{70}$ compararam a infiltração coronária de canais radiculares obturados pelas técnicas da condensação lateral e da Onda Contínua de Condensação, através da penetração de bactérias anaeróbias. A infiltração coronária foi mais rápida nos dentes obturados pela técnica da condensação lateral que nos dentes obturados pela técnica da Onda Contínua de Condensação. Não houve diferença estatisticamente significante no número de dentes que apresentaram infiltração apical entre as duas técnicas avaliadas.

\subsection{3 - Técnica da guta-percha termoplastificada injetável}

\subsubsection{1 - Histórico}

O sistema Ultrafil ${ }^{143}$ se baseou na técnica de obturação da guta-percha termoplastificada injetável em alta temperatura, preconizada por YEE et al. ${ }^{152}$, em 1977. 
$\mathrm{Na}$ técnica de obturação da guta-percha termoplastificada injetável em alta temperatura ${ }^{152}$, inicialmente selecionava-se uma cânula, de modo que a mesma se adaptasse quatro milímetros aquém do ápice radicular. Em seguida, vários cones de guta-percha eram inseridos em uma seringa de pressão e compactados. A seringa era aquecida, durante dois minutos, em um banho de glicerina a $160^{\circ} \mathrm{C}$. Após a plastificação da guta-percha, a cânula era colocada no canal radicular, na profundidade pré-determinada, e a guta-percha injetada no canal. Quando uma leve resistência era sentida, removia-se a seringa lentamente até a completa obturação do canal radicular.

YEE et al. ${ }^{152}$, em 1977, no mesmo trabalho, analisaram a infiltração apical de canais radiculares obturados por diferentes técnicas. Quarenta dentes unirradiculados tiveram seus canais instrumentados e foram divididos em quatro grupos de dez dentes, de acordo com a técnica de obturação utilizada: condensação lateral, condensação vertical aquecida, termoplastificada injetável com cimento e termoplastificada injetável sem cimento. Após a obturação, os dentes foram armazenados em umidade por vinte e quatro horas, impermeabilizados e imersos em solução de azul de metileno por cento e vinte horas. Em seguida, os dentes foram secionados longitudinalmente e a infiltração apical avaliada em microscopia. Os resultados demonstraram que a infiltração apical foi semelhante nas quatro técnicas estudadas. A técnica termoplastificada injetável produziu um selamento apical efetivo, especialmente quando associada ao cimento.

Em relação à qualidade da obturação, TORABINEJAD et al. ${ }^{142}$, em 1978 e YEE et al. ${ }^{152}$, em 1977, verificaram que a técnica de obturação termoplastificada injetável promoveu uma réplica detalhada da anatomia do sistema de canais radiculares, com ótima adaptação da guta-percha às paredes dentinárias e reprodução adequada irregularidades do canal, além da obturação de canais laterais e acessórios.

A técnica de obturação termoplastificada injetável apresenta como vantagens: selamento apical efetivo, fácil manipulação, número de passos reduzidos $^{152}$ e maior rapidez. No entanto, uma grande desvantagem dessa técnica é a alta temperatura $\left(160^{\circ} \mathrm{C}\right)$ que é necessária para que a guta-percha apresente fluidez adequada $62,97,126$. 
No intuito de minimizar os possíveis efeitos indesejáveis decorrentes da alta temperatura utilizada na técnica preconizada por YEE et al. ${ }^{152}$, foi desenvolvido o sistema Ultrafil cujo objetivo principal é o emprego da guta-percha injetável em baixa temperatura.

\subsubsection{2 - Sistema Ultrafil}

O sistema Ultrafil foi desenvolvido pelos endodontistas Michanowicz e Czonstkowsky ${ }^{31,47,97,126}$ e introduzido no mercado pela Hygenic em $1985^{103,109}$. Esse sistema utiliza o mesmo princípio da guta-percha termoplastificada injetável através de uma seringa, preconizado por YEE et al. ${ }^{152}$, em 1977.

No sistema Ultrafil, a guta-percha é injetada no canal em baixa temperatura $\left(70^{\circ} \mathrm{C}\right)$, apresentando uma grande vantagem em relação à técnica original de YEE et al. ${ }^{152}$, onde a guta-percha era plastificada a $160^{\circ} \mathrm{C}{ }^{97,98}$.

O sistema Ultrafil apresenta como vantagens: baixa temperatura de plastificação da guta-percha, rapidez e selamento das irregularidades do canal radicular ${ }^{31,45,97,98}$, inclusive com penetração de guta-percha no interior dos túbulos dentinários ${ }^{109}$.

A dificuldade do sistema Ultrafil se encontra no controle do limite apical da obturação ${ }^{87}$ resultando, em alguns casos, em obturações aquém do comprimento de trabalho ou no extravasamento de material obturador para os tecidos periapicais ${ }^{19,83,84,144}$. Em canais atrésicos ou curvos, onde a inserção da cânula é dificultada, as obturações realizadas com o sistema Ultrafil podem ficar curtas, bem como nos casos em que a guta-percha não foi aquecida suficientemente ou se esfriou na cânula antes da injeção ${ }^{143}$.

2.2.3.3 - Infiltração apical e outras características da obturação realizada com o sistema Ultrafil

MICHANOWICZ; CZONSTKOWSKY ${ }^{97}$, em 1984, verificaram o selamento apical de canais radiculares obturados pela técnica da guta-percha injetável em baixa temperatura $\left(70^{\circ} \mathrm{C}\right)$. Sessenta dentes unirradiculados foram 
instrumentados e divididos em três grupos de vinte, de acordo com a técnica de obturação utilizada: condensação lateral, guta-percha termoplastificada injetável com cimento e guta-percha termoplastificada injetável sem cimento. O cimento utilizado foi o de Grossman. Na técnica injetável, a seringa foi aquecida a $70^{\circ} \mathrm{C}$ e a cânula inserida quatro milímetros no interior do canal radicular. Após a obturação, os dentes foram impermeabilizados e imersos em azul de metileno a $5 \%$ por sete dias. A seguir, os dentes foram seccionados longitudinalmente e a infiltração apical analisada em microscopia. Radiograficamente, os canais radiculares obturados pela técnica termoplastificada injetável apresentaram-se bem obturados, com uma massa uniforme. Quanto à infiltração apical, a técnica apresentou um bom selamento, especialmente quando associada ao cimento.

Um ano mais tarde, em 1985, CZONSTKOWSKY; MICHANOWICZ; VAZQUEZ ${ }^{31}$ avaliaram a infiltração de dentes obturados pelas mesmas técnicas do trabalho anterior ${ }^{97}$, através de isótopos radioativos. Na técnica injetável, os canais foram obturados com guta-percha aquecida a $70^{\circ} \mathrm{C}$, sendo a cânula inserida seis milímetros aquém do comprimento de trabalho. Após a obturação, removeu-se a guta-percha dos terços cervical e médio do canal. Os dentes foram radiografados e mantidos em soro durante uma semana. Após esse período, os dentes foram impermeabilizados e $10 \mathrm{ml}$ de amido radioativo foi colocado no interior dos canais radiculares com o auxílio de uma pipeta. Os três milímetros apicais do dente foram imersos em solução fisiológica durante sete dias. Em seguida, os dentes foram removidos e uma solução de Aquasol foi adicionada à solução fisiológica para determinar a radioatividade. A técnica termoplastificada injetável sem cimento apresentou a maior infiltração apical, enquanto a técnica termoplastificada injetável com cimento, a menor. De uma forma geral, o grau de infiltração exibido nas três técnicas foi pequeno, evidenciando um bom selamento.

\section{MICHANOWICZ; CZONSTKOWSKY; PIESCO ${ }^{98}$, em 1986,} analisaram em microscopia eletrônica de varredura a adaptação da guta-percha do sistema Ultrafil às paredes do canal, com o emprego ou não de cimento. A gutapercha apresentou ótima adaptação às paredes dentinárias, em ambos os casos. 
Quando o sistema Ultrafil foi utilizado sem cimento, observou-se a penetração de guta-percha no interior dos túbulos dentinários. Já quando o cimento foi utilizado, esse fato não foi observado.

Em 1987, GEORGE; MICHANOWICZ; MICHANOWICZ ${ }^{47}$ preconizaram a confecção de uma matriz apical no preparo biomecânico para prevenir o extravasamento da guta-pecha durante a obturação dos canais radiculares com o sistema Ultrafil. A matriz apical deve ser avaliada através da introdução de uma lima número 20 , com força moderada, no canal radicular. Se a lima não ultrapassar o comprimento de trabalho, a matriz é considerada adequada. Caso contrário, a mesma é considerada insatisfatória. Os autores relataram que esse método de preparo do canal mostrou ser prático e eficiente para evitar o extravasamento da guta-percha do sistema Ultrafil durante a obturação dos canais radiculares.

LACOMBE et al. ${ }^{83}$, em 1988, compararam a infiltração apical e o controle do limite da obturação de canais radiculares obturados por diferentes técnicas. Sessenta e cinco dentes anteriores superiores foram instrumentados e divididos de acordo com a técnica de obturação empregada: condensação lateral, Ultrafil e Obtura, utilizando-se o cimento de Grossman. Após a obturação, os dentes foram mantidos em umidade por quarenta e oito horas e impermeabilizados. Em seguida, foram imersos em azul de metileno a $2 \%$, por quarenta e oito horas, e seccionados longitudinalmente. A infiltração apical foi determinada através de dois métodos: infiltração linear de corante (com auxílio de um microscópio) e espectrofotometria (através da dissolução do dente e determinação da concentração de azul de metileno na solução). Os resultados da infiltração linear de corante demonstraram que a técnica da condensação lateral mostrou menor infiltração que as duas técnicas de guta-percha injetável, as quais não apresentaram diferença estatisticamente significante entre si. Já a espectrofotometria mostrou que não houve diferença estatisticamente significante entre as três técnicas avaliadas. Isso demonstra uma diferença nos resultados de acordo com a metodologia de avaliação. Em relação ao limite da obturação, os dentes obturados pelo sistema Ultrafil 
apresentaram maior número de extrusão de material obturador, seguido por aqueles do sistema Obtura e da condensação lateral.

ZUOLO et al. ${ }^{153}$, em 1988, estudaram a infiltração apical de canais radiculares obturados por diferentes técnicas. Trinta incisivos centrais superiores foram instrumentados, impermeabilizados e divididos em três grupos de dez, de acordo com a técnica de obturação utilizada: Ultrafil sem cimento, Ultrafil associado à condensação lateral sem cimento e condensação lateral realizada com o cimento $N$ Rickert. Após a obturação, os dentes foram imersos em azul de metileno a 0,5\%, por setenta e duas horas, e seccionados longitudinalmente. A infiltração apical foi avaliada com o auxílio de um microscópio. O sistema Ultrafil associado à condensação lateral mostrou menor infiltração apical, sendo esse procedimento recomendado pelos autores.

Em 1988, CALLIS; PATERSON ${ }^{27}$ avaliaram a infiltração apical de canais radiculares obturados por diferentes técnicas, utilizando diferentes métodos. Quarenta e oito dentes unirradiculados foram instrumentados e obturados pela técnica da condensação lateral ou pelo sistema Ultrafil, utilizando-se o cimento Tubliseal. Após a obturação, os dentes foram armazenados em soro por uma semana e impermeabilizados. Em ambos os grupos os dentes foram subdivididos em três subgrupos, de acordo com o método de avaliação utilizado: infiltração linear de corante (azul brilhante "Procus") e volume de corante radioativo (utilizando-se os corantes sódio cromato marcado com $\mathrm{Cr}^{51}$ e a albumina humana marcada com ${ }^{125}$ ). A infiltração linear foi medida com o auxílio de um projetor e o volume de corante obtido através de um aparelho gama. Em todas as avaliações realizadas não houve diferença estatisticamente significante na infiltração apresentada pelas duas técnicas de obturação.

BRAMANTE et al. $^{19}$, em 1989, compararam a infiltração apical, o extravasamento de material obturador, a qualidade da obturação e o tempo gasto na obturação dos canais radiculares, utilizando diferentes técnicas de obturação. Setenta caninos superiores foram instrumentados e uma pequena porção 
de alginato foi colocada no milímetro final do canal para simular o coto periodontal. Os dentes foram impermeabilizados e divididos em grupos, de acordo com a técnica de obturação utilizada: condensação lateral (com limas tipo Kerr, com pontas Rhein ou com espaçadores manuais), McSpadden, Híbrida de Tagger, Schilder e sistema Ultrafil. O cimento utilizado foi o óxido de zinco e eugenol (exceto no grupo do Ultrafil, onde não se utilizou cimento). Após a obturação, os dentes foram radiografados, imersos em azul de metileno a $2 \%$, por sete dias, e seccionados longitudinalmente. A avaliação da infiltração apical foi realizada em um microscópio. As técnicas da condensação lateral com limas tipo Kerr e Híbrida de Tagger apresentaram menor infiltração apical que as demais e o sistema Ultrafil, a maior. $O$ menor tempo de obturação foi exibido pelas técnicas McSpadden e Ultrafil. O sistema Ultrafil apresentou maior extravasamento apical de material obturador que as demais técnicas. Em relação à qualidade da obturação, as técnicas da condensação lateral foram melhores no terço apical, as termoplastificadoras nos terços cervical e médio, enquanto as obturações realizadas com o sistema Ultrafil mostraram-se deficientes em todos os terços.

Em 1989, BEATTY et al. $^{9}$ verificaram a infiltração apical de canais radiculares obturados por quatro técnicas de obturação. Oitenta caninos foram instrumentados, impermeabilizados e divididos em quatro grupos de vinte, de acordo com a técnica de obturação utilizada: cone único, condensação lateral, Ultrafil e Thermafil. O cimento utilizado foi o Roth 801. Após a obturação, os dentes foram unidos à parede interna de frascos de vidro e a extremidade apical dos dentes imersa em solução aquosa de azul de metileno a 1\% durante duas semanas. Em seguida, os mesmos foram seccionados longitudinalmente e a infiltração apical de corante analisada com o auxílio de um microscópio. Os sistemas de obturação que utilizam guta-percha termoplastificada - Ultrafil e Thermafil - apresentaram menor infiltração apical quando comparados às técnicas da condensação lateral e do cone único. 
Em 1989, OLSON; HARTWELL; WELLER ${ }^{108}$ analisaram o selamento apical de canais radiculares obturados por diferentes técnicas. Noventa dentes foram instrumentados e divididos em três grupos, de acordo com a técnica de obturação utilizada. O terço apical do canal de todos os dentes foi obturado com um cone principal de guta-percha e cimento Roth 801. Os demais terços do canal foram obturados com as seguintes técnicas: condensação lateral, Ultrafil e Obtura. Após a obturação, os dentes foram armazenados em meio úmido por uma semana e impermeabilizados. Em seguida, foram imersos em tinta nanquim por sete dias, desmineralizados, clareados e a infiltração apical analisada com o auxílio de um estereomicroscópio. O sistema Ultrafil apresentou menor infiltração apical quando comparado ao sistema Obtura e à técnica da condensação lateral, os quais não apresentaram diferença estatisticamente significante entre si.

MOURA et al. ${ }^{103}$, em 1989, estudaram a infiltração apical de canais radiculares obturados pelo sistema Ultrafil. Quarenta dentes foram instrumentados e obturados pelo sistema Ultrafil, sendo que em vinte dentes utilizouse o cimento N-Rickert e vinte foram obturados sem cimento. Em metade dos dentes de cada grupo não se utilizou a condensação vertical durante a obturação, enquanto nos dentes restantes a mesma foi utilizada. Após a obturação, os dentes foram impermeabilizados e imersos em solução de azul de metileno a 0,5\% por trinta e seis horas. Em seguida, foram seccionados longitudinalmente e a infiltração apical analisada com o auxílio de um microscópio. Não houve diferença estatisticamente significante na infiltração apresentada pelos diferentes grupos avaliados. Os autores concluíram que o Ultrafil é um bom sistema para obturar os canais radiculares, principalmente se associado à condensação vertical.

MICHANOWICZ et al. $^{99}$, em 1989, avaliaram o sucesso clínico e radiográfico de pacientes que tiveram seus canais radiculares obturados com o sistema Ultrafil (associado ou não ao cimento) e com a técnica da condensação lateral ativa após um período de dois anos. Os autores verificaram que houve um alto índice de sucesso com o emprego de ambas as técnicas. O número de lesões reduziu de $44 \%$ para $15 \%$ em canais obturados pela técnica da 
condensação lateral e de $59 \%$ para $5 \%$ em canais obturados pelo sistema Ultrafil. 0 emprego do cimento associado ao sistema Ultrafil não influenciou na porcentagem de sucesso.

Em 1990, GREENE; WONG; INGRAM ${ }^{57}$ compararam a infiltração apical de canais radiculares obturados por diferentes técnicas. Trinta e dois dentes anteriores foram instrumentados e divididos em quatro grupos, de acordo com a técnica de obturação utilizada: condensação lateral, Ultrafil, Canal Finder e técnica da guta-percha seccional aquecida. O cimento utilizado foi o Roth 801, exceto para o grupo do Canal Finder, onde se utilizou o Endo Technic Canal Sealer Paste. Os dentes foram impermeabilizados, amarrados com fio dental em um tubo e os ápices imersos em solução de azul de metileno a 0,25\% durante sete dias. A seguir, foram seccionados transversalmente e a infiltração apical de corante analisada. Os resultados demonstraram que não houve diferença estatisticamente significante na infiltração apical apresentada pelos grupos avaliados.

LAMBRIANIDIS et al. ${ }^{84}$, em 1990, verificaram a infiltração apical e o limite da obturação de canais radiculares obturados com guta-percha termoplastificada injetável. Noventa incisivos inferiores e pré-molares foram instrumentados, cobertos com papel alumínio e incluídos em blocos de resina acrílica. Todos os canais radiculares foram obturados com guta-percha termoplastificada injetável e cimento Roth 801 , sendo que os dentes foram divididos em três grupos, de acordo com a profundidade da inserção da cânula durante a obturação: $4 \mathrm{~mm}, 6 \mathrm{~mm}$ e $8 \mathrm{~mm}$ aquém do ápice. Em seguida, realizou-se a condensação vertical da obturação. Os dentes foram removidos dos blocos de resina e os dois milímetros apicais dos mesmos foram imersos em tinta nanquim, durante três dias, em temperatura ambiente. $\mathrm{Na}$ seqüência, os dentes foram desmineralizados, clareados e a infiltração apical avaliada. A profundidade da inserção da cânula nos diferentes comprimentos - 4mm, $6 \mathrm{~mm}$ e $8 \mathrm{~mm}$ aquém do ápice - não mostrou diferença estatisticamente significante na infiltração apical dos canais radiculares. Quanto à extensão da guta-percha, nos dentes em que a cânula 
foi posicionada oito milímetros aquém do ápice, a porcentagem de subobturação foi maior que nos demais grupos.

Em 1991, GOLDBERG et al. ${ }^{50}$ analisaram em microscopia eletrônica de varredura a superfície das guta-perchas de consistência regular e firme do sistema Ultrafil. As amostras de consistência firme apresentaram-se mais lisas e menos irregulares que as amostras de consistência regular. Dessa forma, provavelmente a guta-percha de consistência firme promove reações adversas menos severas que a regular quando em contato direto com os tecidos periapicais.

BUDD, WELLER; KULILD ${ }^{24}$, em 1991, compararam a qualidade da obturação de canais radiculares obturados por diferentes técnicas: condensação lateral, Ultrafil e Obtura. A técnica da condensação lateral apresentou melhor controle do limite da obturação e pior qualidade da obturação que os sistemas Ultrafil e Obtura, os quais não apresentaram diferença estatisticamente significante entre si.

DONLEY et al. ${ }^{34}$, em 1991, avaliaram a temperatura intracanal durante a obturação do canal radicular com os sistemas Ultrafil e Obtura. A temperatura média que a guta-percha apresentou quando saiu da cânula foi de aproximadamente $63^{\circ} \mathrm{C}$ para o sistema Ultrafil e $138^{\circ} \mathrm{C}$ para o sistema Obtura. A média de temperatura intracanal apresentada pelo sistema Ultrafil foi $30,8^{\circ} \mathrm{C}$, enquanto a apresentada pelo sistema Obtura foi $55,5^{\circ} \mathrm{C}$. Os autores relataram que a guta-percha se esfriou rapidamente após ser injetada no canal radicular em ambos os sistemas.

$$
\text { Em 1992, VEIS et } \text { al. }^{144} \text { repetiram o trabalho de }
$$
LAMBRIANIDIS et al. ${ }^{84}$, de 1990, variando apenas o modo da condensação vertical. A condensação vertical em vez de ser realizada apenas ao término da obturação, como no caso anterior, foi realizada em três fases. Após cada fase de injeção da guta-percha, a mesma era condensada verticalmente com condensadores manuais. Os resultados, em relação à infiltração apical, foram semelhantes aos do trabalho 
anterior. A técnica da injeção da guta-percha com condensação vertical em três fases reduziu o risco de subobturação dos canais, apresentando-se como uma melhoria da técnica da injeção da guta-percha termoplastificada com condensação apenas após o término da obturação.

AMDITIS et al. $^{4}$, em 1992, estudaram a adaptação e o selamento apical de canais radiculares obturados por diferentes técnicas, utilizando diferentes métodos. Quarenta e dois dentes foram instrumentados e divididos em quatro grupos, de acordo com a técnica de obturação empregada: condensação lateral, técnica de McSpadden, ultra-sônica com ENAC e sistema Ultrafil, utilizandose o cimento Procosol. Após a obturação, os dentes foram radiografados, armazenados em umidade por vinte e quatro horas e impermeabilizados. A infiltração apical dos dentes foi testada inicialmente através do método eletroquímico, diariamente, durante trinta dias. Após trinta dias, avaliou-se a infiltração através da penetração de corante. Os terços apicais dos dentes foram imersos em azul de metileno a $2 \%$ por quarenta e oito horas. Em seguida, os dentes foram seccionados longitudinalmente e a infiltração apical analisada através de visualização direta. Os dois métodos de avaliação da infiltração (eletroquímico e corante) mostraram que a infiltração apresentada pelas quatro técnicas foi similar, sendo que no método eletroquímico a técnica da condensação lateral apresentou um maior número de canais sem infiltração apical. Radiograficamente, todas as técnicas apresentaram, no mínimo, nove entre dez obturações boas ou aceitáveis. As técnicas da condensação lateral e ultra-sônica apresentaram melhor controle do limite da obturação que as demais.

SCOTT; VIRE ${ }^{126}$, em 1992, verificaram que canais radiculares obturados com o sistema Ultrafil, nos quais foram confeccionados previamente um tampão de dentina apical com uma lima Hedstroen, apresentaram uma quantidade de material obturador extravasado muito menor quando comparados aos canais onde o tampão de dentina não foi confeccionado. 
Em 1993, KARAGÖZ-KÜÇÜKAY; KÜÇÜKAY; BAYIRLI ${ }^{77}$ analisaram a influência da armazenagem dos dentes após a obturação e do emprego da centrífuga na infiltração apical dos canais radiculares. Oitenta e quatro dentes humanos foram instrumentados, impermeabilizados e obturados com a gutapercha de consistência regular do sistema Ultrafil, empregando-se o cimento CRCS. Os dentes foram divididos em dois grupos, sendo que em um deles os mesmos foram imersos no corante após a obturação, enquanto no outro foram armazenados em umidade por setenta e duas horas (para que ocorresse a presa do cimento) e, posteriormente, imersos no corante. Em metade dos dentes de cada grupo, utilizouse uma centrífuga para remoção do ar durante vinte minutos, previamente à imersão dos dentes no corante, sendo que na outra metade os dentes foram colocados no corante de maneira passiva. Todos os dentes permaneceram em tinta nanquim durante setenta e duas horas e, em seguida, foram desmineralizados e clareados. A infiltração apical foi analisada com o auxílio de um estereomicroscópio. Em todos os grupos, os dentes obturados pelo sistema Ultrafil apresentaram pequena infiltração apical. Não houve diferença estatisticamente significante na infiltração apical dos dentes que foram imersos no corante após a obturação ou após setenta e duas horas e nem entre os dentes onde a penetração do corante foi realizada de maneira passiva ou utilizando a centrífuga.

Em 1993, SOARES; ROCHA ${ }^{132}$ avaliaram a infiltração apical e o nível da obturação de canais radiculares obturados pelo sistema Ultrafil. Trinta e dois caninos superiores foram instrumentados, impermeabilizados e obturados pelo sistema Ultrafil, sendo que em metade deles não se utilizou cimento e na outra metade foi utilizado o cimento de óxido de zinco e eugenol. Após a obturação, os dentes foram imersos em plasma sangüíneo com azul de metileno a $2 \%$ por sete dias. Os dentes foram radiografados para a averiguação do nível da obturação e seccionados para a avaliação da infiltração apical, a qual foi realizada com um paquímetro. Não houve diferença estatisticamente significante na infiltração apical dos dentes obturados com o sistema Ultrafil quando foi utilizado ou não cimento. A coincidência entre o nível da obturação e o limite de instrumentação foi rara. A 
quantidade de subobturações foi pequena, enquanto que a de sobreobturações foi alta em ambos os grupos.

GENÇOGLU SAMANI; GÜNDAY ${ }^{45}$, em 1993, compararam a adaptação da guta-percha de canais radiculares obturados pela técnica da condensação lateral e pelos sistemas Thermafil e Ultrafil, na presença ou não da "smear layer". Os sistemas Ultrafil e Thermafil apresentaram melhor adaptação da guta-percha às paredes do canal, com melhor reprodução das suas irregularidades quando comparados à técnica da condensação lateral. A remoção da "smear layer" promoveu melhora na adaptação do material obturador ao canal, sendo esse efeito mais pronunciado no sistema Ultrafil.

No mesmo ano de 1993, GENÇOGLU, SAMANI; GÜNDAY46 verificaram a influência da "smear layer" na infiltração apical de cento e vinte canais radiculares obturados por diferentes técnicas. Em metade deles, a "smear layer" foi removida com EDTA a 17\%, enquanto nos restantes a "smear layer" foi preservada. Em seguida, os dentes foram esterilizados e divididos em três grupos, de acordo com a técnica de obturação empregada: condensação lateral, Ultrafil e Thermafil, utilizando-se o cimento de Grossman. Após a obturação, os dentes foram implantados no tecido subcutâneo de ratos, por noventa dias, e removidos. Em seguida, os dentes foram impermeabilizados e imersos em solução aquosa de azul de metileno a $1 \%$ durante duas semanas. Na seqüência, os dentes foram desmineralizados e clareados e a infiltração apical avaliada em um microscópio. A remoção da "smear layer" promoveu uma redução na infiltração apical em todas as técnicas de obturação avaliadas. Em ambos os grupos (com "smear layer" removida ou não) a técnica da condensação lateral apresentou maior infiltração quando comparada aos sistemas que utilizam guta-percha termoplastificada - Ultrafil e Thermafil - os quais não apresentaram diferença estatisticamente significante entre si. Os dentes obturados pelo sistema Ultrafil apresentaram obturação homogênea e bem adaptada às irregularidades do canal radicular e canais laterais e acessórios obturados com guta-percha. 
DALAT; SPANGBERG ${ }^{32}$, em 1994, compararam a infiltração apical de canais radiculares obturados por diferentes técnicas. Setenta e cinco dentes anteriores foram instrumentados e divididos em cinco grupos de quinze, de acordo com a técnica de obturação empregada: cone único, condensação lateral, condensação vertical, Thermafil e Ultrafil, utilizando-se o cimento AH26. Após a obturação, os dentes foram armazenados em umidade por uma semana e impermeabilizados. Em seguida, foram imersos em solução aquosa de azul de metileno a $2 \%$, sob um vácuo de pressão de 75 torr por trinta minutos. Após os dentes serem removidos do vácuo, eles permaneceram no corante a $37^{\circ} \mathrm{C}$, durante sete dias, e foram secionados longitudinalmente. A infiltração apical foi avaliada através de um estereomicroscópio. Não houve diferença estatisticamente significante na infiltração apical apresentada pelas diferentes técnicas de obturação dos canais radiculares.

Em 1994, KARAGÖZ-KÜÇÜKAY; BAYIRLI ${ }^{76}$ avaliaram o selamento apical de canais radiculares obturados pelo sistema Ultrafil. Oitenta e oito dentes anteriores foram instrumentados e divididos em dois grupos. No primeiro, a "smear layer" foi mantida, enquanto no segundo foi removida com EDTA a 20\%. Em seguida, os dentes foram impermeabilizados e os grupos divididos em dois subgrupos, sendo que em um deles os dentes foram obturados apenas com o sistema Ultrafil e no outro se associou o cimento CRCS. A infiltração apical foi avaliada através do método eletroquímico. De um modo geral, os dentes onde a "smear layer" foi removida apresentaram menor infiltração apical que aqueles onde a mesma foi preservada. O uso do cimento não mostrou diferença estatisticamente significante na infiltração apical em ambos os grupos ("smear layer" removida ou preservada). Quando o cimento foi utilizado, os dentes onde a "smear layer" foi removida apresentaram menor infiltração que os dentes onde a "smear layer" estava presente. Já quando o cimento não foi utilizado, não houve diferença estatisticamente significante entre os grupos onde a "smear layer" foi removida ou não. 
No mesmo ano de 1994, em outro trabalho, KARAGÖZKÜÇÜKAY ${ }^{75}$ verificou a capacidade do sistema Ultrafil em obturar as ramificações do canal radicular dos incisivos inferiores. O sistema Ultrafil mostrou-se efetivo na obturação das ramificações do canal principal desses dentes, porém apresentou grande quantidade de extravasamento de material obturador.

HOLLAND et al. ${ }^{67}$, em 1995, analisaram o selamento apical apresentado pelos diferentes tipos de guta-percha do sistema Ultrafil. Quarenta dentes foram instrumentados, impermeabilizados e divididos em quatro grupos de dez. No primeiro grupo, os canais radiculares foram obturados pela técnica da condensação lateral e nos demais pelo sistema Ultrafil, utilizando guta-percha de diferentes consistências: "regular set", "firm set" e "endo set", as quais possuem cânulas da cor branca, azul e verde, respectivamente. O cimento utilizado foi o óxido de zinco e eugenol. Nos dentes obturados pelo sistema Ultrafil, utilizou-se um cone de guta-percha principal e o restante do canal foi preenchido pela guta-percha plastificada do sistema. Após a obturação, os dentes foram imersos em uma solução de azul de metileno a $2 \%$ em ambiente de vácuo. Após vinte e quatro horas, os dentes foram removidos do corante, seccionados longitudinalmente e a infiltração apical analisada com o auxílio de uma ocular milimetrada e uma lupa estereoscópica. O melhor selamento foi observado com o emprego das guta-perchas "regular set" e "firm set" do sistema Ultrafil, sendo que a técnica da condensação lateral ocupou posição intermediária e a guta-percha "endo set" apresentou o pior resultado.

Em 1995, PERRONE et al. ${ }^{112}$ avaliaram, em microscopia eletrônica de varredura, canais radiculares obturados pela técnica da condensação lateral e pelo sistema Ultrafil. Em ambos os grupos não foi utilizado cimento durante a obturação. O sistema Ultrafil promoveu uma obturação mais homogênea que a técnica da condensação lateral, com reprodução adequada das irregularidades do canal radicular, inclusive com a obturação de canais laterais por guta-percha. No entanto, esse sistema apresentou um maior número de sobreobturações quando comparado à técnica da condensação lateral. 
HATA et al. ${ }^{62}$, em 1995, verificaram o selamento apical dos canais radiculares através da infiltração de uma resina especial nos vazios da obturação. Cento e cinqüenta dentes unirradiculados foram instrumentados e divididos em diferentes grupos, de acordo com a técnica de obturação realizada: Thermafil, Obtura II, Ultrafil "firm set" e Ultrafil "regular set", utilizando ou não cimento endodôntico. A técnica da condensação lateral associada ao cimento foi utilizada como grupo controle. Após a obturação, os dentes foram mantidos em temperatura ambiente durante dois dias e impermeabilizados. A seguir, foram imersos em uma resina "resorcinol formaldeído", por cinco dias, a $4^{\circ} \mathrm{C}$ e por quatro dias, em temperatura ambiente, para que a polimerização da resina se completasse. Os dentes foram seccionados transversalmente a 1,5, 2,5 e 3 milímetros aquém do ápice e as secções examinadas e fotografadas em um estereomicroscópio. Não houve diferença estatisticamente significante na infiltração apical apresentada pelas diferentes técnicas, nos diferentes níveis. No entanto, as técnicas exibiram menor infiltração apical quando associadas ao cimento.

WU; GEE; WESSELINK ${ }^{150}$, em 1997, estudaram a infiltração apical de canais radiculares obturados com o sistema Ultrafil. Oitenta caninos tiveram sua porção coronária e seus ápices removidos, originando secções radiculares de cinco milímetros de comprimento. As secções radiculares foram instrumentadas e divididas em dois grupos de quarenta, de acordo com o cimento utilizado na obturação: Ketac Endo e AH26. Em metade das secções de cada grupo utilizou-se a condensação vertical, enquanto na outra metade não. Todas as secções radiculares foram obturadas pelo sistema Ultrafil. Após a obturação, as mesmas foram mantidas em umidade a $37^{\circ} \mathrm{C}$, por uma semana, impermeabilizadas e a infiltração apical foi avaliada através do método de transporte de fluido. Quando a condensação não foi realizada, os dois cimentos não mostraram diferença estatisticamente significante na infiltração apical. Porém, quando se realizou a condensação, o Ketac Endo mostrou menor infiltração que o AH26. Em relação ao cimento, quando se utilizou o AH26, a condensação não promoveu melhora no selamento. Já quando o Ketac Endo foi utilizado, a condensação proporcionou um melhor selamento. 
HOLLAND; MURATA; DEZAN JUNIOR ${ }^{63}$, em 1997, compararam o selamento apical de canais radiculares obturados por diferentes técnicas. Cinqüenta dentes foram instrumentados, impermeabilizados e divididos em cinco grupos de dez, de acordo com a técnica de obturação utilizada: condensação lateral a frio, condensação lateral aquecida, realizada com o Endotec, Ultrafil sem cimento, Ultrafil com cimento e Ultrafil associado a um cone principal de guta-percha e cimento. O cimento utilizado foi o oxido de zinco e eugenol. Após a obturação, os dentes foram radiografados e armazenados em umidade por vinte e quatro horas. Em seguida, foram imersos em solução de azul de metileno a $2 \%$ sob vácuo. Após vinte e quatro horas, foram removidos do corante e seccionados longitudinalmente. A infiltração apical dos dentes foi avaliada com o auxílio de uma ocular milimetrada e uma lupa estereoscópica. A técnica da condensação lateral aquecida, realizada com o Endotec, apresentou a menor infiltração apical, enquanto o Ultrafil sem cimento, a maior, não selando de forma conveniente o canal radicular. Os autores recomendam que o sistema Ultrafil deva ser associado a um cimento obturador e a um cone principal de guta-percha com o objetivo de promover um melhor selamento apical e um maior controle do limite da obturação.

Em 1997, OTANI; MOURA; BARBOSA ${ }^{109}$ verificaram a reação inflamatória do tecido periapical de dentes de cães que tiveram seus canais radiculares obturados com o sistema Ultrafil. Nos casos de extravasamento do material obturador, aos noventa dias, observava-se a presença de um infiltrado linfoplasmocitário e a presença de células gigantes adjacentes ao material extravasado. Quando o material não era extravasado nos tecidos periapicais, observava-se uma reparação tecidual após trinta dias. Tal fato demonstra que o processo de reparo é influenciado pela presença ou não de material obturador em contato com os tecidos periapicais.

Em 1999, ARTAZA 6 avaliou o selamento apical de canais radiculares obturados por diferentes técnicas. Cinqüenta dentes unirradiculados foram instrumentados e divididos em quatro grupos, de acordo com a técnica de obturação utilizada: condensação lateral a frio, condensação lateral aquecida com o 
Endotec, Híbrida e sistema Ultrafil, utilizando-se o cimento de Grossman. Após a obturação, os dentes foram radiografados e armazenados em umidade a $37^{\circ} \mathrm{C}$ por sete dias. Em seguida, os dentes foram impermeabilizados e imersos em tinta nanquim durante cinco dias. Os dentes foram desmineralizados e clareados e a infiltração apical foi avaliada com o auxílio de um microscópio. Não houve diferença estatisticamente significante na infiltração apical apresentada pelas diferentes técnicas. Radiograficamente, os dentes onde foi utilizado o sistema Ultrafil apresentaram uma obturação densa e homogênea, com adaptação adequada e reprodução das irregularidades das paredes do canal.

AL-DEWANI; HAYES; DUMMER ${ }^{1}$, em 2000, analisaram a capacidade de selamento apical e a qualidade radiográfica apresentada por duas técnicas de obturação. Cem dentes unirradiculados foram instrumentados, sendo que em cinqüenta foram preparados canais paralelos (com nenhum ou pouco desgaste na embocadura do canal) e em cinqüenta canais cônicos (com desgaste mais acentuado na embocadura do canal). Após a instrumentação, os canais radiculares foram irrigados com EDTA a 17\%. Ambos os grupos (canais paralelos e cônicos) foram divididos em dois subgrupos, de acordo com a técnica de obturação utilizada: condensação lateral e sistema Ultrafil, utilizando-se o cimento Tubliseal. Após a obturação, os dentes foram radiografados e mantidos em meio úmido por setenta e duas horas. A seguir, foram impermeabilizados e imersos em tinta nanquim durante duas semanas. Após esse período, os dentes foram desmineralizados e clareados e a infiltração apical analisada em um estereomicroscópio. O sistema Ultrafil apresentou melhor selamento apical, porém pior qualidade radiográfica da obturação e maior extrusão de material obturador quando comparado à técnica da condensação lateral. Não houve diferença estatisticamente significante na infiltração apical em relação à forma do preparo do canal. 


\subsection{4 - Técnica da guta-percha plastificada termomecanicamente}

2.2.4.1 - Histórico

O sistema JS Quick-Fill possivelmente teve suas origens baseadas na Técnica da Compactação Termomecânica, a qual foi preconizada por McSpadden, em 1979, durante a reunião da Associação Americana de Endodontia ${ }^{17,41}$.

Na Técnica da Compactação Termomecânica são utilizados compactadores, que são instrumentos semelhantes às limas tipo Hedstroen

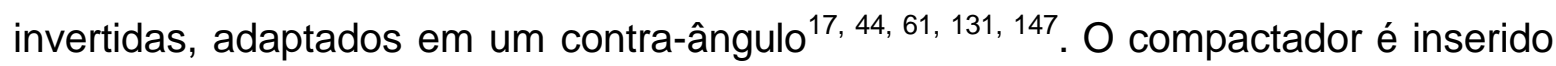
no canal radicular, que contém um cone de guta-percha previamente assentado, e acionado. A rotação do compactador gera um calor friccional que plastifica a gutapercha, empurrando-a apicalmente e lateralmente realizando, dessa forma, a obturação do canal radicular ${ }^{44,61,135}$.

A técnica de McSpadden resulta em uma obturação densa e adaptada às paredes do canal ${ }^{147}$. Apresenta como vantagens: rapidez e praticidade de execução ${ }^{44,147}$ e como desvantagens: falta de controle do limite da obturação, fratura de instrumentos ${ }^{44,145}$ e dificuldade de ser usada em canais curvos ${ }^{87,147}$.

\subsubsection{2 - Sistema JS Quick-Fill}

O sistema JS Quick-Fill foi recentemente introduzido no mercado empregando uma técnica de obturação do canal radicular termoplastificada mecanicamente ${ }^{127}$. A técnica é semelhante à preconizada por McSpadden, porém, em vez de a guta-percha ser inserida previamente no canal radicular, ela é levada juntamente com o compactador.

$\mathrm{Na}$ técnica de obturação como sistema JS Quick-Fill, um compactador de titânio revestido por guta-percha é adaptado a um micromotor, em baixa rotação, e inserido no canal radicular. Durante sua rotação, o contato entre o compactador e as paredes do canal gera um calor friccional ${ }^{28,58}$, que promove a plastificação da guta-percha ${ }^{111,}{ }^{122}$, impulsionando-a apicalmente ${ }^{111}$. Após esse 
processo, o compactador é removido do interior do canal radicular ou poderá ser deixado no mesmo, se desejado ${ }^{111,122,127 .}$

O sistema JS Quick-Fill apresenta como vantagens facilidade $^{127}$ e rapidez ${ }^{58}$ da técnica e como desvantagem dificuldade no controle da extensão do material obturador ${ }^{58}$.

2.2.4.3 - Infiltração apical e outras características da obturação realizada com o sistema JS Quick-Fill

PALLARÉS; FAUS ${ }^{110}$, em 1995, compararam o selamento apical de canais radiculares obturados por duas técnicas. Quarenta incisivos centrais superiores foram instrumentados e divididos em dois grupos, de acordo com a técnica de obturação utilizada: condensação lateral ou sistema JS Quick-Fill, utilizando-se o cimento AH26. Após a obturação, os dentes foram armazenados em soro fisiológico por vinte e quatro horas. Em seguida, foram impermeabilizados e imersos em tinta nanquim durante setenta e duas horas. Os dentes foram desmineralizados e clareados e a infiltração apical avaliada com o auxílio de um estereomicroscópio. Não houve diferença estatisticamente significante na infiltração apical apresentada pelas duas técnicas avaliadas. Os dentes obturados pelo sistema JS Quick-Fill mostraram uma obturação na qual a guta-percha localizava-se no centro e o cimento próximo às paredes dentinárias. A espessura da camada de cimento aumentava progressivamente do terço apical ao terço coronário.

PALLARÉS; FAUS, GLICKMAN ${ }^{111}$, em 1995, analisaram a adaptação da guta-percha do sistema JS Quick-Fill às paredes dentinárias em microscopia eletrônica de varredura. Em metade dos dentes a "smear layer" foi removida com ácido cítrico e, na outra metade, preservada. O cimento utilizado foi o AH26. Em todos os espécimes, o cimento foi encontrado em contato com as paredes dentinárias, mas não foi observado no interior da massa de guta-percha. Quando a "smear layer" foi removida, observou-se guta-percha e cimento no interior dos túbulos dentinários, fato não verificado quando a mesma estava presente. Os autores concluíram que quando a "smear layer" é removida ocorre uma melhor 
adaptação entre a guta-percha plastificada mecanicamente e as paredes do canal radicular.

Em 1995, SAUNDERS; SAUNDERS ${ }^{122}$ avaliaram a infiltração coronária de canais radiculares obturados pela técnica da condensação lateral e pelo sistema JS Quick-Fill. Foram utilizados os cimentos Sealapex e Apexit. Os canais obturados pela técnica da condensação lateral apresentaram menor infiltração coronária que os obturados pelo sistema JS Quick-Fill. Na técnica da condensação lateral não houve diferença estatisticamente significante na infiltração mostrada pelos dois tipos de cimento. Já no sistema JS Quick-Fill, o cimento Sealapex apresentou maior infiltração que o Apexit.

\section{CANALDA-SAHLI; BERÁSTEGUI-JIMENO; BRAU-} AGUADÉ ${ }^{28}$, em 1997, verificaram o selamento apical de canais radiculares obturados por diferentes técnicas. Sessenta incisivos e caninos superiores foram instrumentados e divididos em três grupos de vinte, de acordo com a técnica de obturação avaliada: condensação lateral, sistema Multiphase e sistema JS Quick-Fill, utilizando-se o cimento AH Plus. Após a obturação, os dentes foram mantidos em meio úmido por quarenta e oito horas. Em seguida, foram impermeabilizados e imersos em tinta nanquim por quarenta e oito horas. Na seqüência, os dentes foram desmineralizados e clareados e a infiltração apical foi avaliada com o auxílio de um estereomicroscópio. Não houve diferença estatisticamente significante na infiltração apical apresentada pelas diferentes técnicas avaliadas. Nenhum espécime obturado pela técnica Multiphase apresentou infiltração de corante. Apenas um espécime do grupo da condensação lateral e um do sistema JS Quick-Fill apresentaram infiltração apical de corante.

Em 1997, SHAKESPEARE; DONNELLY ${ }^{127}$ compararam o selamento apical de canais radiculares obturados por duas técnicas de obturação. Trinta dentes unirradiculados foram instrumentados e divididos em dois grupos de quinze, de acordo com a técnica de obturação empregada: condensação lateral ou sistema JS Quick-Fill, utilizando-se o cimento Roth 801. Após a obturação, os dentes 
foram mantidos em umidade. Em seguida, foram impermeabilizados e imersos em tinta nanquim durante sete dias. Os dentes foram desmineralizados e clareados e a infiltração apical foi avaliada com o auxílio de um estereomicroscópio. Os canais radiculares obturados pela técnica da condensação lateral mostraram menor infiltração apical quando comparados aos obturados pelo sistema JS Quick-Fill.

Em 1998, GULABIVALA, HOLT; LONG ${ }^{58}$ analisaram o selamento apical, o tempo de obturação e a extrusão de material obturador de canais radiculares obturados por diferentes técnicas. Cento e dezesseis canais radiculares foram utilizados nesse estudo e divididos em cinco grupos. Nos grupos de um a quatro, os canais foram instrumentados com limas manuais e obturados com as seguintes técnicas: condensação lateral, JS Quick-Fill, Thermafil e Alphaseal. No quinto grupo, os canais foram preparados com instrumentos rotatórios e obturados com o sistema Alphaseal. Em todos os grupos utilizou-se o cimento de Roth. Após a obturação, os dentes foram mantidos em umidade por três dias. Em seguida, foram impermeabilizados e imersos em tinta nanquim durante três dias. Os dentes foram desmineralizados e clareados e a infiltração apical foi avaliada com o auxílio de um estereomicroscópio. O sistema Alphaseal apresentou o maior número de dentes sem infiltração apical, enquanto o JS Quick-Fill, o maior número de dentes com infiltração e a maior extensão da infiltração que os demais grupos. A técnica da condensação lateral promoveu o melhor controle do limite da obturação, enquanto o sistema o JS Quick-Fill apresentou o maior número de canais subobturados, e os sistemas Thermafil e Alphaseal o maior número de sobreobturações. As técnicas de obturação que utilizam guta-percha termoplastificada foram mais rápidas quando comparadas à técnica da condensação lateral.

\subsection{5 - Técnica da guta-percha termoplastificada associada a um cone principal}

\subsubsection{1 - Histórico}

O sistema Microseal originou-se a partir do sistema Multiphase, proposto por MCSPADDEN ${ }^{96}$, em 1993. 
O sistema Multiphase é composto por um compactador de níquel-titânio, duas seringas de guta-percha (uma do tipo alfa e a outra do tipo beta) e um aparelho aquecedor. As duas seringas de guta-percha são aquecidas e o compactador é introduzido inicialmente na seringa de guta-percha tipo beta e posteriormente na guta-percha tipo alfa ${ }^{48,135}$. O compactador, envolvido pelos dois tipos de guta-percha, é levado ao canal radicular e acionado em um contra-ângulo, promovendo a obturação do canal radicular $28,48,78,96$.

GILHOOLY et al. ${ }^{48}$, em 2000 e KATAIA; EL SAYED ${ }^{78}$, em 1994, comparando a infiltração apical dos canais radiculares obturados com as técnicas da condensação lateral e Multiphase observaram que a técnica Multiphase apresentou menor infiltração apical.

A técnica Multiphase apresenta a vantagem de usar gutaperchas com diferentes propriedades físicas, associando a rigidez da guta-percha tipo beta à baixa viscosidade, alta fluidez e boa adesividade da guta-percha tipo alfa $^{33,48,78,96}$. No entanto, segundo GILHOOLY et al. ${ }^{48}$, em 2000, uma grande desvantagem dessa técnica é a falta de controle do limite da obturação, a qual pode resultar no extravasamento de material obturador para os tecidos periapicais.

Com o objetivo de corrigir a desvantagem do sistema Multiphase - falta de controle do limite da obturação - a Tycom modificou esse sistema e introduziu recentemente no mercado o sistema Microseal ${ }^{33}$.

\subsubsection{2 - Sistema Microseal}

O sistema Microseal é um sistema de obturação misto, que utiliza um cone principal de guta-percha associado à guta-percha termoplastificada. A guta-percha termoplastificada é inserida no canal radicular com um compactador de níquel-titânio e se funde ao cone principal, previamente assentado, formando uma massa homogênea no interior do canal radicular ${ }^{81,131}$.

O sistema Microseal apresenta as seguintes vantagens: simplicidade, rapidez, eficiência ${ }^{118}$ e controle do limite apical da obturação. sistema Microseal combina as vantagens das técnicas tradicionais às mais recentes tecnologias $^{39}$. 
2.2.5.3 - Infiltração apical e outras características da obturação realizada com o sistema Microseal

DAVALOU, GUTMANN; NUNN ${ }^{33}$, em 1999, avaliaram a infiltração apical de canais radiculares obturados com os sistemas Microseal e System B. Oitenta dentes unirradiculados foram instrumentados, irrigados com EDTA para remoção da "smear layer" e divididos em dois grupos, de acordo com o sistema de obturação utilizado: System B e Microseal. O cimento utilizado foi o Kerr Pulp Canal Sealer. Após a obturação, os dentes foram mantidos em meio úmido por dez dias, impermeabilizados e imersos em tinta nanquim durante dez dias. Os dentes foram desmineralizados, clareados e a infiltração apical avaliada com o auxílio de um estereomicroscópio. Todos os canais obturados com os sistemas Microseal e System B (exceto um) apresentaram infiltração apical menor que um milímetro. Não houve diferença estatisticamente significante na infiltração apical apresentada pelas duas técnicas, sendo ambas efetivas no preenchimento das irregularidades do canal radicular.

Em 1999, REZENDE; BOMBANA ${ }^{118}$ compararam a infiltração apical de canais radiculares obturados por diferentes técnicas. Vinte e quatro incisivos e caninos superiores foram instrumentados, impermeabilizados e divididos em três grupos, de acordo com a técnica de obturação utilizada: condensação vertical, utilizando-se o cimento N-Rickert e sistema Microseal (associado ou não ao cimento do grupo anterior). Após a obturação, os dentes foram imersos em solução de azul de metileno a 0,5\%, por quarenta e oito horas, e seccionados longitudinalmente. A infiltração apical foi avaliada com o auxílio de um projetor. Não houve diferença estatisticamente significante na infiltração apical apresentada pelos diferentes grupos avaliados.

BONETTI FILHO et al. ${ }^{15}$, em 2000, verificaram o selamento apical de canais radiculares obturados por diferentes técnicas. Trinta incisivos centrais superiores foram instrumentados e divididos em dois grupos, de acordo com a técnica de obturação utilizada: condensação lateral e sistema Microseal, utilizando- 
se o cimento Fill Canal. Após a obturação, os dentes foram impermeabilizados, colocados sob vácuo durante dez minutos e imersos em solução de azul de metileno a $2 \%$ durante vinte e quatro horas. Na seqüência, os dentes foram seccionados longitudinalmente e a infiltração apical avaliada com o auxílio de um projetor. Os canais radiculares obturados pelo sistema Microseal apresentaram melhor selamento apical quando comparados aos obturados pela técnica da condensação lateral ativa.

Em 2001, MAZOTTI ${ }^{93}$ analisou a qualidade da obturação de canais radiculares obturados por diferentes técnicas. Foi utilizado um modelo de dente seccionado, no qual foram confeccionadas irregularidades previamente à obturação. Os canais radiculares foram obturados pelas seguintes técnicas: condensação lateral ativa, híbrida modificada, condensação lateral com o ultra-som, Thermafil, Microseal e System B. O sistema Microseal apresentou melhor homogeneidade da obturação, melhor preenchimento das depressões confeccionadas na raiz e menor número de falhas na obturação, quando comparado às demais técnicas avaliadas.

\section{3 - Técnicas de avaliação da infiltração apical}

A infiltração apical pode ser avaliada através da penetração de corantes ${ }^{15,33,127,128}$ ou radioisótopos ${ }^{27,31,60}$ entre a obturação e as paredes do canal radicular ${ }^{89}$.

Para a avaliação da infiltração apical com corante, após a obturação do canal radicular, o dente é imerso no mesmo por um período préestabelecido e, posteriormente, a infiltração apical será determinada através da marcação do corante na dentina ${ }^{140,149}$. Vários tipos de corante como o azul de metileno $^{101}, 105,128,{ }^{139}$, tinta nanquim ${ }^{77,}{ }^{121}$, eosina ${ }^{139}$, rhodamine $B^{100,}{ }^{133}$, fluoresceína ${ }^{133}$, "procion" brilhante verde ou azul ${ }^{138,139}$ e violeta de genciana ${ }^{133}$ têm sido utilizados para avaliação da infiltração apical. 
A avaliação da infiltração apical com radioisótopos é realizada através da imersão do dente, após a obturação do canal radicular, em uma solução contendo isótopos radioativos ${ }^{27}$. Esses isótopos penetram no canal radicular e marcam a infiltração apical evidenciada, posteriormente, através de autoradiografias $^{100}$. Dentre os isótopos radioativos utilizados encontram-se: $\mathrm{Ca}^{45}, \mathrm{I}^{125}, \mathrm{C}^{14}$ e o $\operatorname{Cr}^{51}(27,31,59,92,140)$.

Para que se tenha acesso à infiltração, os dentes podem ser diafanizados $^{58,89}$ ou seccionados nos sentidos longitudinal ${ }^{63,131}$ ou transversal ${ }^{59,139}$. O seccionamento é mais utilizado que a diafanização por ser mais simples, rápido e econômico ${ }^{107}$.

O método de diafanização para avaliação da infiltração apical foi proposto por TAGGER et al. ${ }^{138}$, em 1983. Esses autores associaram o método de diafanização dos dentes - utilizado anteriormente para o estudo da anatomia dos canais radiculares - com a infiltração de corante, para a avaliação da infiltração apical. Nesse método, os dentes, após serem removidos do corante, são desmineralizados em ácido nítrico, desidratados em soluções crescentes de álcool e, finalmente, clareados em metil salicilato proporcionando a visualização da infiltração apical através da transparência dos espécimes. Essa técnica apresenta como vantagens a visualização tridimensional da obturação e a preservação da estrutura dentária $^{107}$.

A infiltração apical também pode ser avaliada através da penetração bacteriana ${ }^{8,71,151}$. Nesse método, a porção coronária da raiz é inserida em um reservatório que contém bactérias inoculadas em um meio de cultura e o terço apical é introduzido em outro reservatório com o mesmo meio de cultura, porém sem bactérias. Em seguida, as raízes são mantidas em meio adequado para a proliferação bacteriana. Quando o meio de cultura no qual o ápice encontra-se inserido torna-se turvo, indica a proliferação de bactérias no mesmo, evidenciando a infiltração das bactérias através da obturação do canal.

As técnicas de avaliação da infiltração apical que utilizam radioisótopos e bactérias não são muito utilizadas porque requerem materiais sofisticados para sua realização ${ }^{115}$. 
Outros métodos de avaliação da infiltração apical baseiam-se na determinação do volume da infiltração apical. Entre eles se encontram: método eletroquímico $^{3}, 71,115$, espectrofotometria ${ }^{69}, 83,149$, determinação de isótopos radioativos através do aparelho gama ${ }^{27,59}$, transporte de fluido ${ }^{113,} 150,151$ e reconstrução tridimensional da raiz ${ }^{89}$.

O método eletroquímico foi introduzido por JACOBSON; VON FRAUNHOFER ${ }^{71}$, em 1976, e consiste na avaliação da infiltração apical através da corrente elétrica formada por dois eletrodos (condutores metálicos). Um eletrodo é inserido no interior do canal radicular (ânodo) e o outro eletrodo (catodo) em uma solução química (geralmente cloreto de potássio), na qual se encontra inserido o dente. Os dois eletrodos são conectados em um potenciômetro. Quando ocorre a infiltração apical de cloreto de potássio na obturação do canal radicular, forma-se uma corrente elétrica entre os dois eletrodos possibilitando a determinação do volume da infiltração apical ${ }^{3,71,115}$.

A espectrofotometria possibilita a determinação do volume de corante infiltrado no canal radicular através da dissolução do dente em uma solução ácida e determinação da concentração de corante na solução ${ }^{69,}$ 83, 149 .

A infiltração apical de isótopos radioativos também pode ser determinada através de um aparelho gama ${ }^{27,59,60}$. Nesse método, o dente é seccionado transversalmente e o volume de isótopos radioativos presentes em cada secção do dente é determinado pelo aparelho gama, permitindo a avaliação da infiltração apical nos vários níveis do canal radicular ${ }^{59,60}$.

O método de transporte de fluido, para avaliação da infiltração, foi introduzido por WU et al. ${ }^{151}$ em 1993. Nesse método, um tubo plástico adaptado na porção coronária da raiz é preenchido com água. Um outro tubo de plástico é utilizado, sendo que uma das suas extremidades fica em contato com a região apical da raiz e a outra com um tubo capilar (tubo de vidro de diâmetro reduzido). O tubo capilar é preenchido por água, contendo uma bolha de ar no seu interior. Em seguida, no tubo adaptado à porção coronária da raiz aplica-se uma pressão na água com a finalidade de forçar a sua passagem através dos vazios da obturação. A infiltração é determinada através do movimento da bolha de ar dentro 
do capilar, o que indicará a quantidade de água que atravessou a obturação do canal $^{80,113,150,151}$.

Recentemente, em 2000, LYROUDIA et al. ${ }^{89}$ preconizaram um novo método para avaliação do volume da infiltração apical denominado reconstrução tridimensional. Por esse método, após a remoção do dente do corante, o mesmo é cortado transversalmente em um micrótomo, em secções de 0,75 milímetros de espessura. As secções são fotografadas e as imagens transmitidas para um computador. Em cada imagem (secção transversal) é marcado o contorno externo do dente, o canal radicular e a infiltração de corante. Em seguida, através de um programa, é realizado um alinhamento das secções transversais, promovendo a reconstrução tridimensional do dente. O volume da infiltração apical pode ser avaliado em cada secção da raiz, e também no dente como um todo, sob diferentes ângulos. 


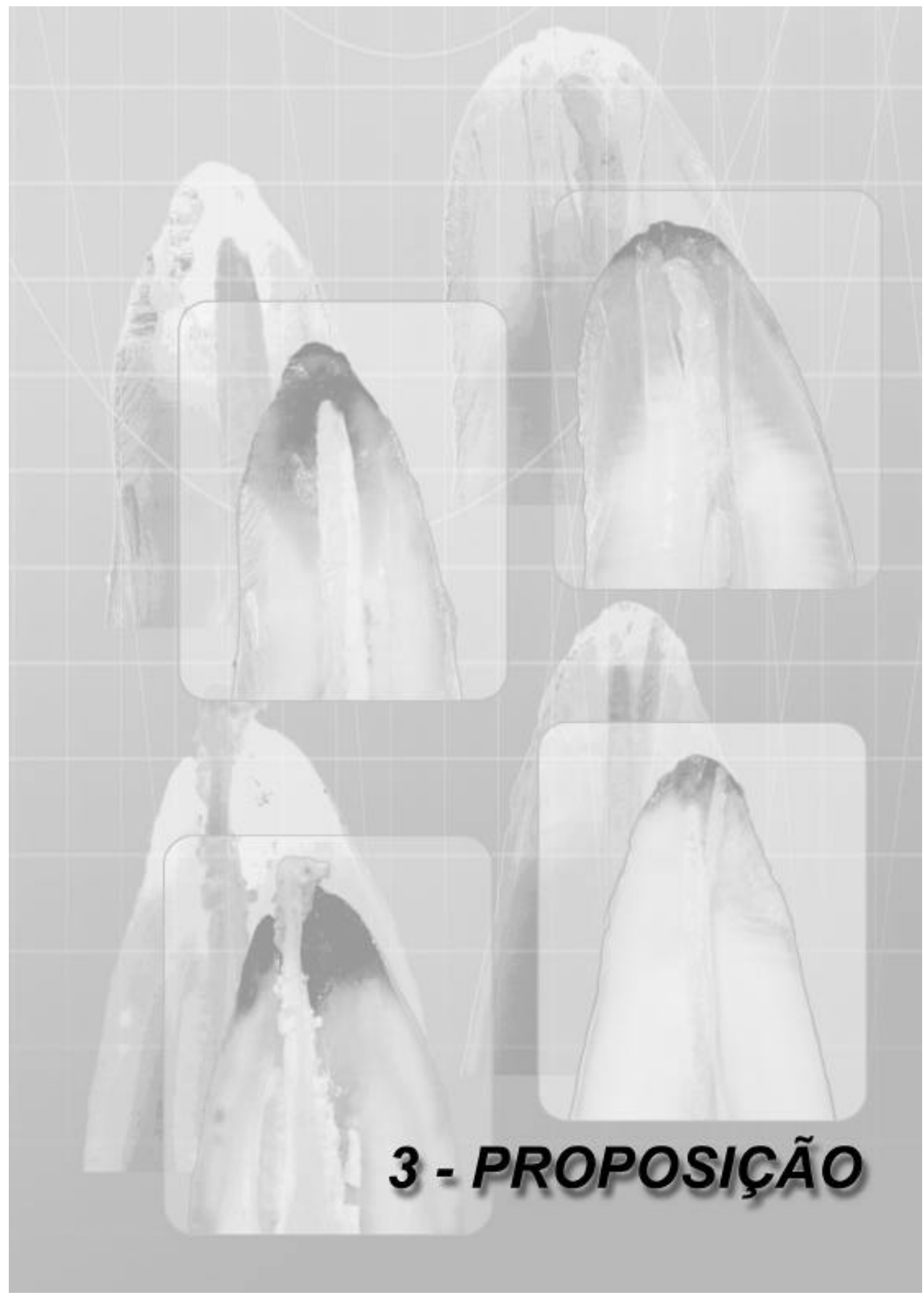




\section{3 - PROPOSIÇÃO}

Este trabalho teve como objetivo avaliar "in vitro", através da infiltração linear de corante, o selamento apical de canais radiculares obturados por diferentes técnicas:

จู Condensação Lateral realizada com lima tipo Kerr;

จู. Onda Contínua de Condensação realizada com o System B;

과 Guta-percha termoplastificada injetável realizada com o sistema Ultrafil;

과 Guta-percha termoplastificada mecanicamente realizada com o sistema JS Quick-Fill;

ㄱ․ Guta-percha termoplastificada associada a um cone principal realizada com o sistema Microseal. 


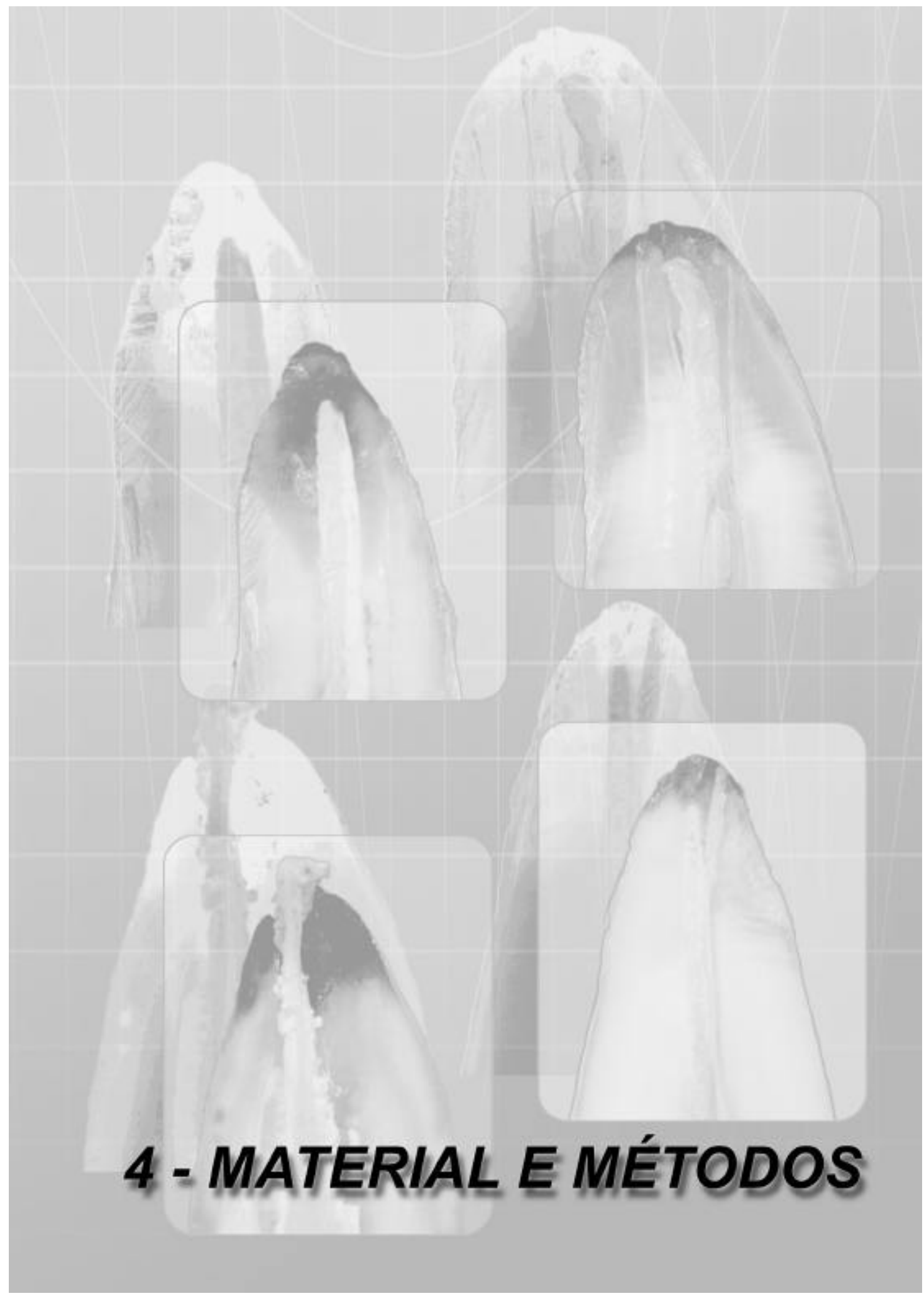




\section{4 - MATERIAL E MÉTODOS}

\section{1 - Sistemas de obturação utilizados}

4.1.1 - System B

O System $\mathrm{B}^{(\mathrm{a})}$ é um aparelho gerador de calor que funciona com baterias recarregáveis. Apresenta vários componentes ${ }^{(b)}$ : (Figura 2).

과 $A$ - botão vertical para ligar e desligar o aparelho.

과 $B$ - botão giratório para controlar a capacidade de calor transmitida à ponta do condensador. A potência aumenta linearmente do número 1 ao 10.

과 C - botão giratório que controla a temperatura da ponta do condensador de 100 a $600^{\circ} \mathrm{C}$.

จ D - visor que mostra a temperatura da ponta do condensador.

고 $\mathrm{E}$ - botão vertical que seleciona o modo de operação. No modo "continuous" a ponta é aquecida continuamente. No modo "touch" a ponta é aquecida apenas quando a chave do aparelho é ativada.

จู $F$ - luz de aquecimento verde, que se acende quando a ponta do System B (condensador) está aquecida.

과 $G$ - dispositivo que permite que a operação do System B seja ativada com um controle de pé.

O System B, através de um cabo, transmite o calor para o condensador denominado "plugger"(a) (Figura 3A). As pontas dos condensadores são disponíveis em diferentes diâmetros: $F$ (fino), FM (médio-fino), M (médio) e ML (grande) para se adaptarem aos diferentes tipos de canais radiculares ${ }^{104,136,137}$. O fabricante do System $B^{137}$ indica para essa técnica a utilização de cones de gutapercha não estandardizados Autofit $^{(a)}$ (Figura 3B), que são encontrados em diferentes calibres, compatíveis com os diâmetros dos condensadores.

\footnotetext{
(a) Analytic Endodontics - Sybron Endo - Califórnia - USA

(b) System B heat source model 1005: instruction guidelines
} 


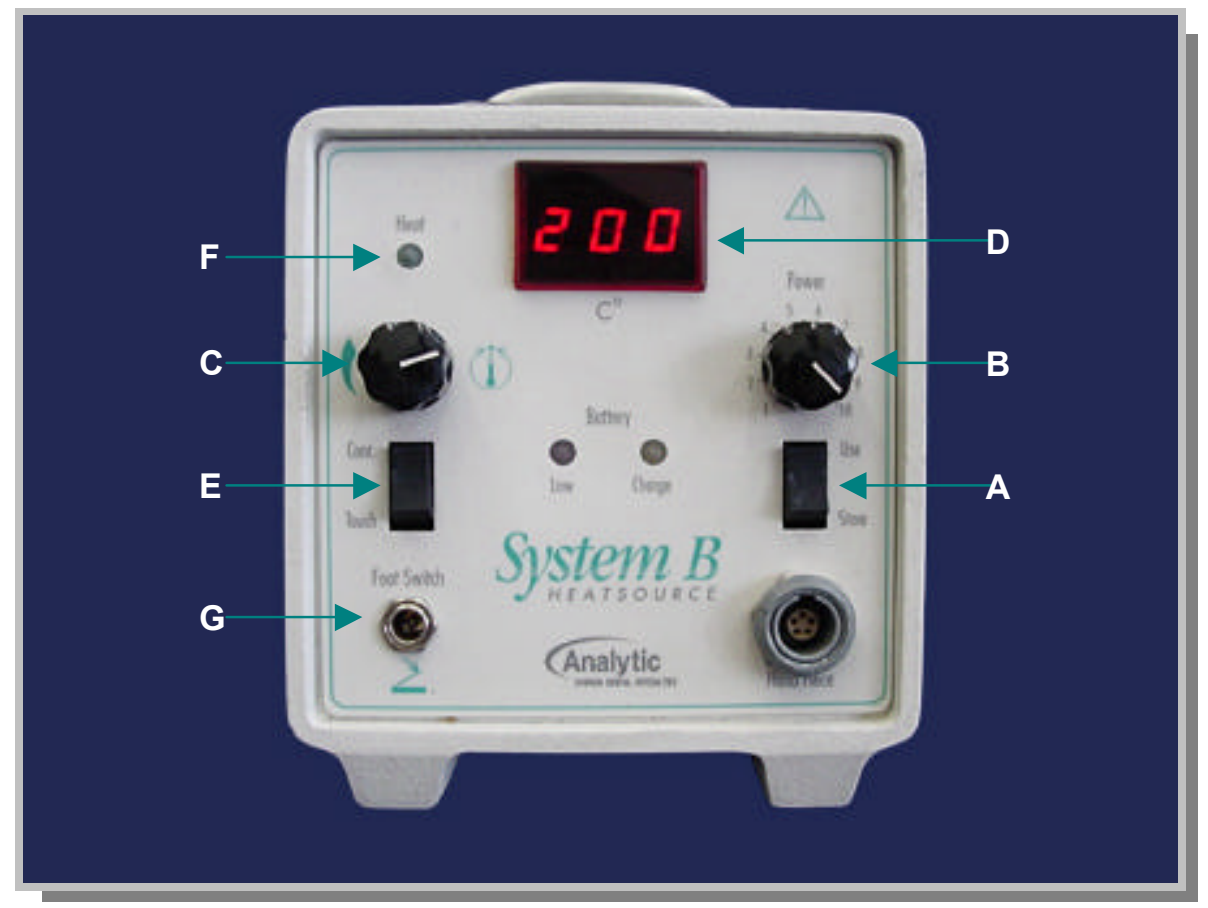

FIGURA 2 - Aparelho System B - A- botão "liga/desliga"; B- botão "potência"; Cbotão "controle de temperatura"; D- visor de temperatura; E- botão "modo de operação"; F- luz de aquecimento e G- "controle de pé"
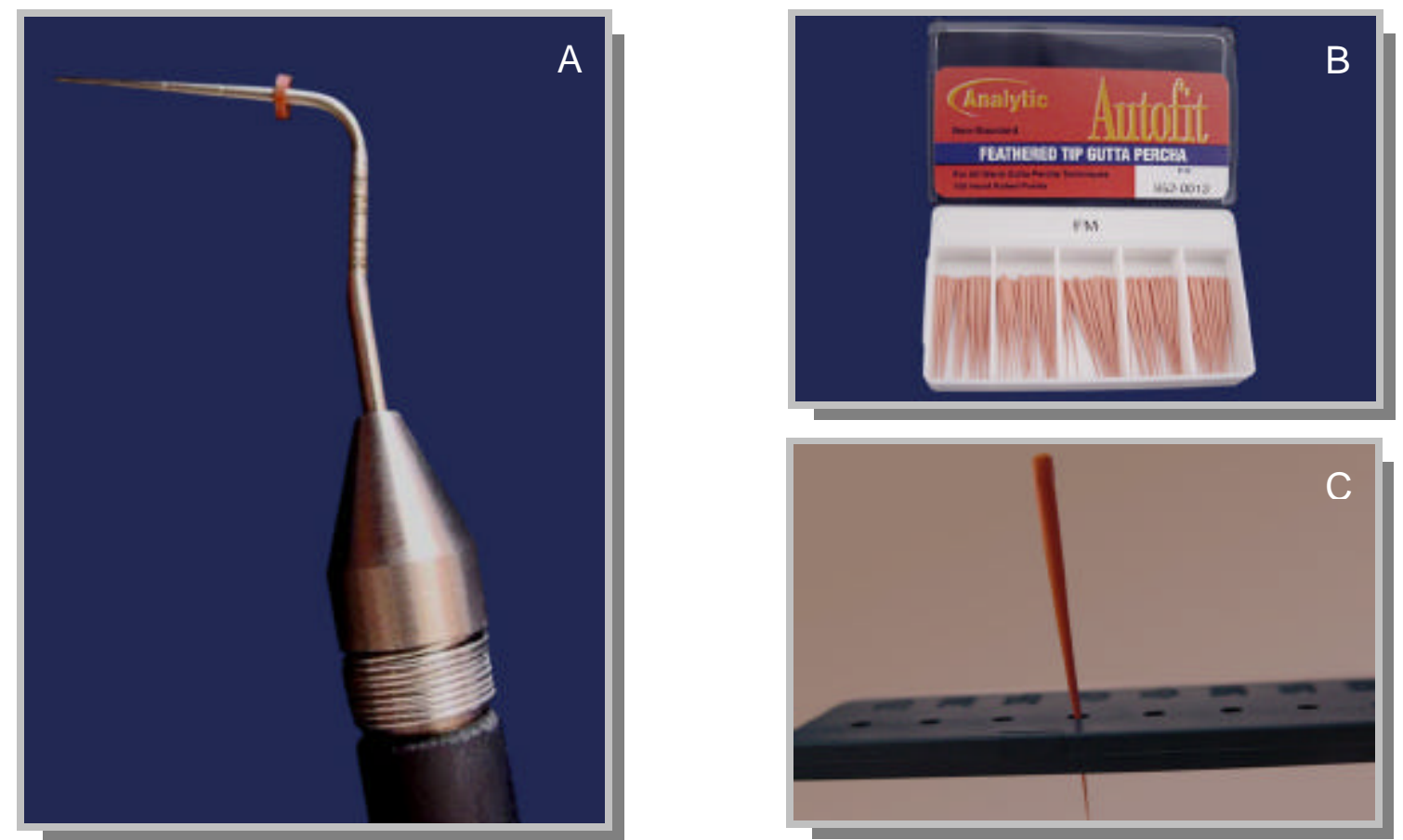

FIGURA 3 - A- Condensador FM do System B; B- Cone Autofit FM; C- Cone Autofit FM inserido na régua calibradora 


\subsection{2 - Ultrafil}

O sistema Ultrafil ${ }^{(a)}$ é composto por um aquecedor portátil, uma seringa de injeção e por cânulas de guta-percha ${ }^{24,57,143}$.

O aquecedor portátil ${ }^{(a)}$ apresenta temperatura de $90^{\circ} \mathrm{C}$, que é controlada através de um termostato, não requerendo nenhum ajuste ou monitoramento. $\mathrm{O}$ aquecedor portátil permite que a guta-percha atinja a temperatura de $70^{\circ} \mathrm{C}$ para que a mesma apresente fluidez adequada ${ }^{57,143}$ (Figura 4).

A seringa(a) do sistema Ultrafil apresenta um ajuste que permite que a cânula seja girada na posição mais adequada para cada canal radicular. Um repetido mecanismo de pressão e soltura do gatilho da seringa faz com que o pistão da seringa empurre o êmbolo da cânula de guta-percha e a mesma seja inserida no canal radicular ${ }^{143}$ (Figura 5A).

A guta-percha $^{(a)}$ é acondicionada no interior de cânulas, que apresentam um êmbolo de plástico em uma extremidade e uma agulha de aço inoxidável na outra. As cânulas apresentam quantidade de guta-percha suficiente para obturar um dente multirradiculado e devem ser descartadas quando vazias. Devem ser desinfetadas em solução química ${ }^{143}$ (Figura 5B).

O sistema Ultrafil apresenta a guta-percha em três diferentes viscosidades para promover uma maior versatilidade na obturação dos canais radiculares, adaptando-se a diferentes técnicas e situações clínicas. As guta-perchas "regular set" (branca) e "firm set" (azul) apresentam maior fluidez e são indicadas para técnicas de obturação mais simples. O tempo de endurecimento é a principal diferença entre as duas (trinta minutos e quatro minutos, respectivamente). A gutapercha "endo set" (verde) apresenta maior viscosidade e menor fluidez. Apresenta tempo de endurecimento de dois minutos e é indicada para técnicas que requerem condensação ${ }^{1,50,143}$.

As diferentes guta-perchas do sistema Ultrafil apresentam exatamente a mesma fórmula dos cones de guta-percha da Hygenic (ingredientes e proporção dos componentes). A maior fluidez dessas guta-perchas é conseguida através do processo de industrialização ${ }^{97,143}$.

\footnotetext{
(a) Hygenic - Coltène/Waledent Inc. - USA
} 

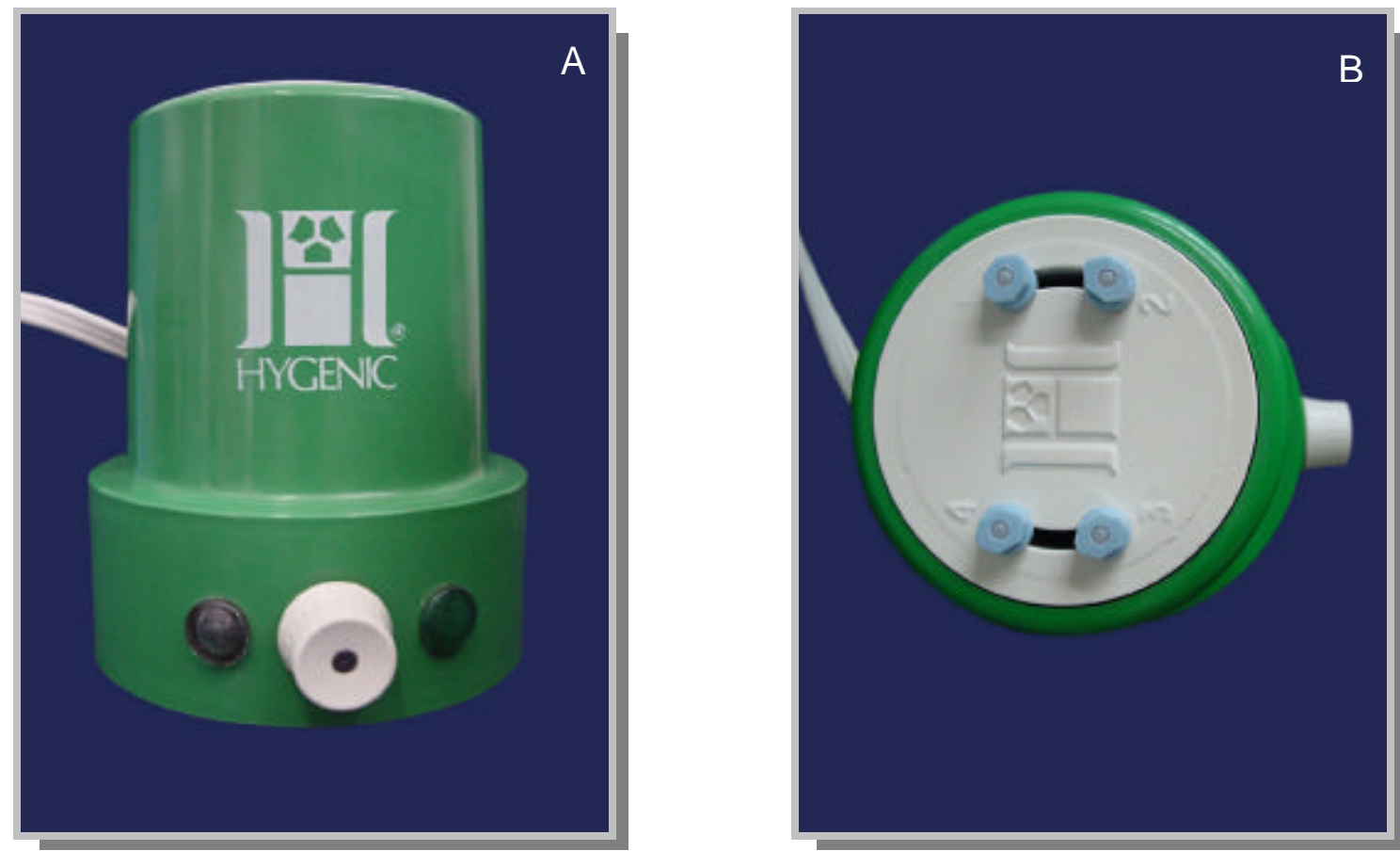

FIGURA 4 - Aquecedor do sistema Ultrafil. A- Vista frontal ; B- Vista superior
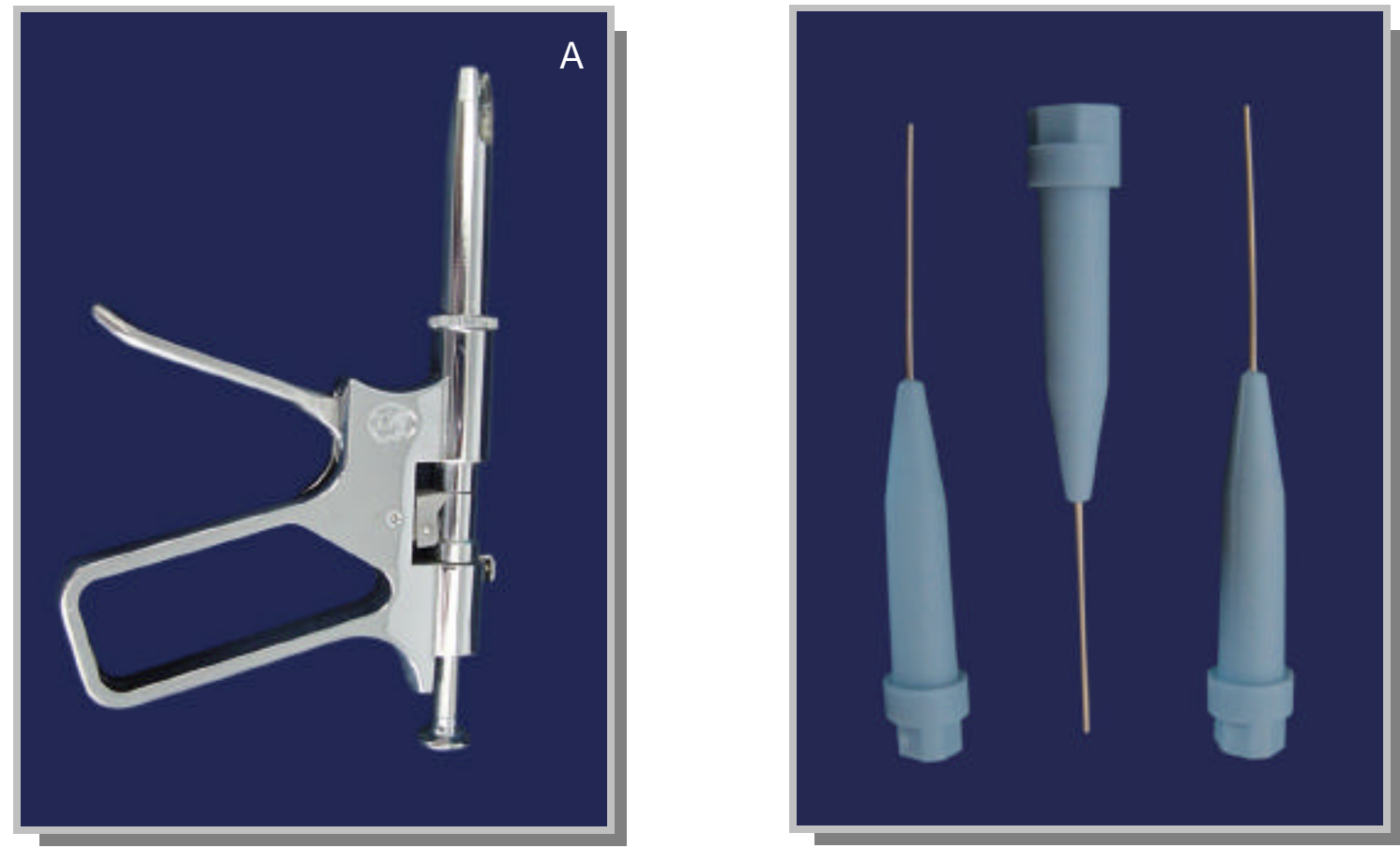

FIGURA 5 - Componentes do sistema Ultrafil. A- seringa; B- cânulas azuis, preenchidas por guta-percha de consistência firme 


\subsection{3 - JS Quick-Fill}

O sistema JS Quick-Fill ${ }^{(a)}$ possui compactadores de titânio recobertos com guta-percha alfa ${ }^{110,111,116,127,135}$, nos comprimentos de 21 e 25 milímetros. Os compactadores são fabricados nos calibres de 15 a 60 e distribuídos em embalagens com quatro unidades ${ }^{73,132}$ (Figura 6).
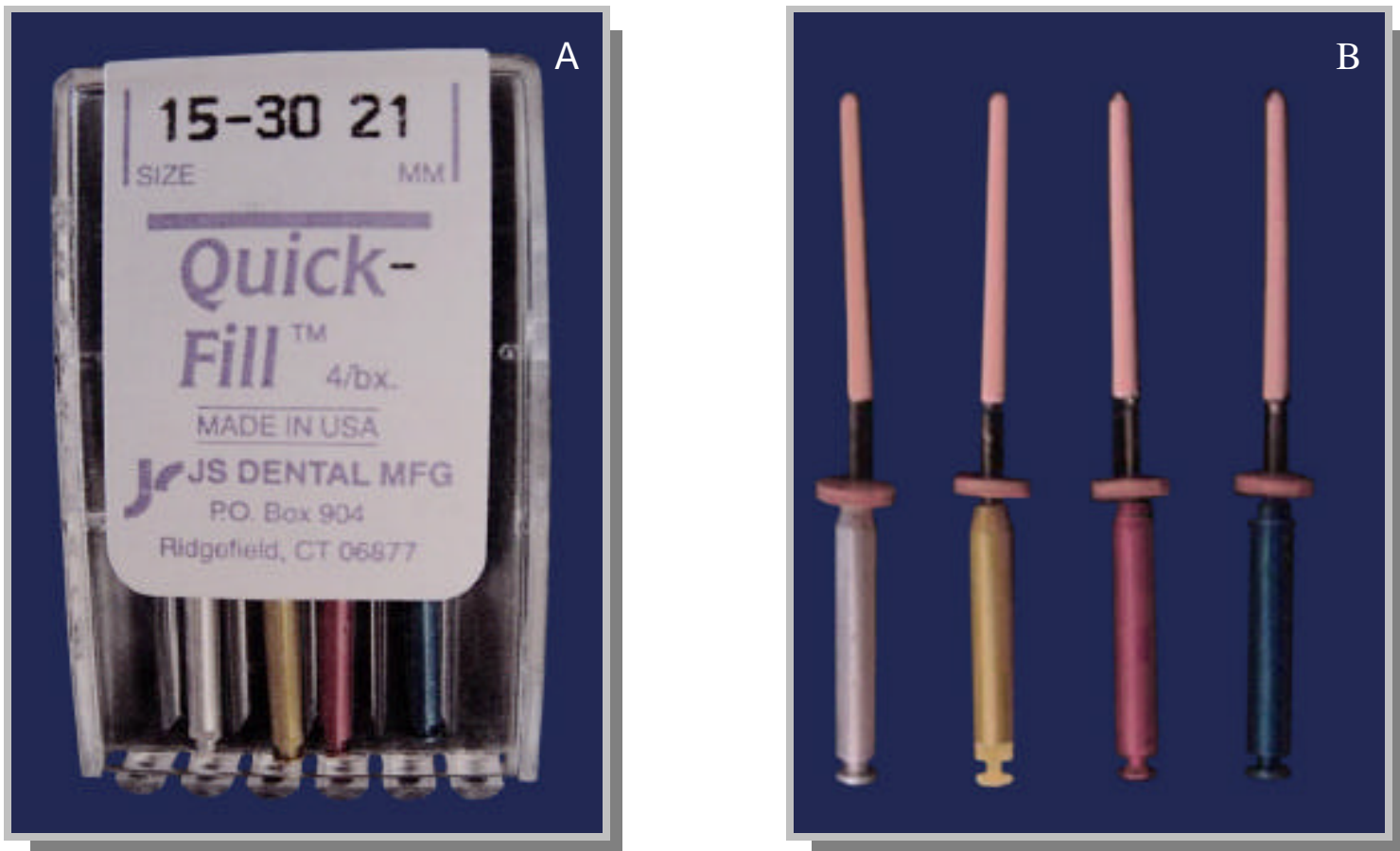

FIGURA 6 - A e B - Compactadores do sistema JS Quick-Fill, no 15 ao 30, de 21 milímetros de comprimento

(a) JS Dental Manufacturing. Inc. - USA 


\subsection{4 - Microseal}

O sistema Microseal ${ }^{(a)}$ é composto por um aquecedor, uma seringa, cones principais de guta-percha, cartuchos de guta-percha e compactadores de níquel-titânio ${ }^{39}$.

O aquecedor Microseal ${ }^{(a)}$ é controlado através de um termostato para manter a temperatura ideal dos cartuchos de guta-percha. A temperatura de trabalho é atingida em menos de 30 segundos $^{39}$ (Figura 7A).

A seringa Microflow ${ }^{(a)}$ é autoclavável e de fácil manuseio. Nela se adapta 0 cartucho de guta-percha Microflow para que seja levado ao aquecedor $^{39}$ (Figura 7A).

Os cones principais Microflow ${ }^{(a)}$ são compostos por gutapercha de baixa fusão, a qual é processada para apresentar fluidez quando submetida à pressão dos compactadores ${ }^{81}$. Apresentam a rigidez necessária para atingirem o comprimento de trabalho e possuem uma certa flexibilidade para acompanharem as curvaturas do canal radicular (Figura 7B). São disponíveis em pontas com diâmetro ISO de 25 a 60 e conicidade 0,02 e no diâmetro 25, com conicidade $0,04^{39}$.

Os cartuchos Microflow ${ }^{(a)}$ possuem guta-percha de baixa fusão, a qual apresenta viscosidade adequada para apresentar boa aderência às paredes do canal. $O$ formato do cartucho permite uma distribuição homogênea de calor $^{39}$ (Figura 7C).

A guta-percha do cone principal não possui a mesma composição da guta-percha do cartucho, sendo assim, elas apresentam viscosidade e temperatura de fusão diferentes ${ }^{39,81}$.

O compactadores Microseal ${ }^{(a)}$ são instrumentos de níqueltitânio, disponíveis nas conicidades 0,02 e 0,04. Têm a função de introduzir, plastificar e condensar a guta-percha no interior do canal radicular ${ }^{39}$ (Figura 8).

(a) Analytic Endodontics - Sybron Endo - Califórnia - USA 

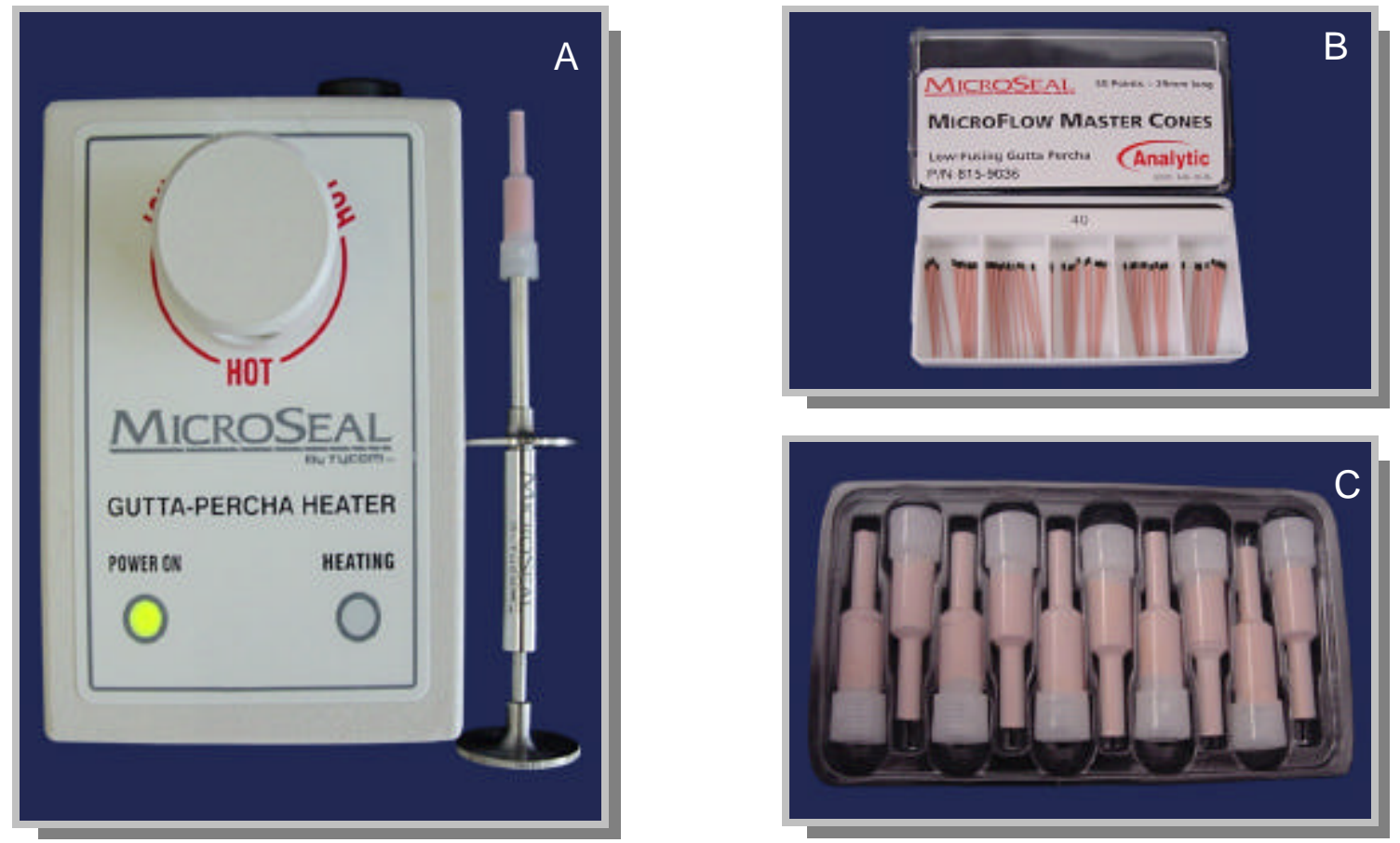

FIGURA 7 - Componentes do sistema Microseal. A- aquecedor e seringa Microflow; B- cone principal Microflow nํ 40; C- cartuchos de guta-percha Microflow
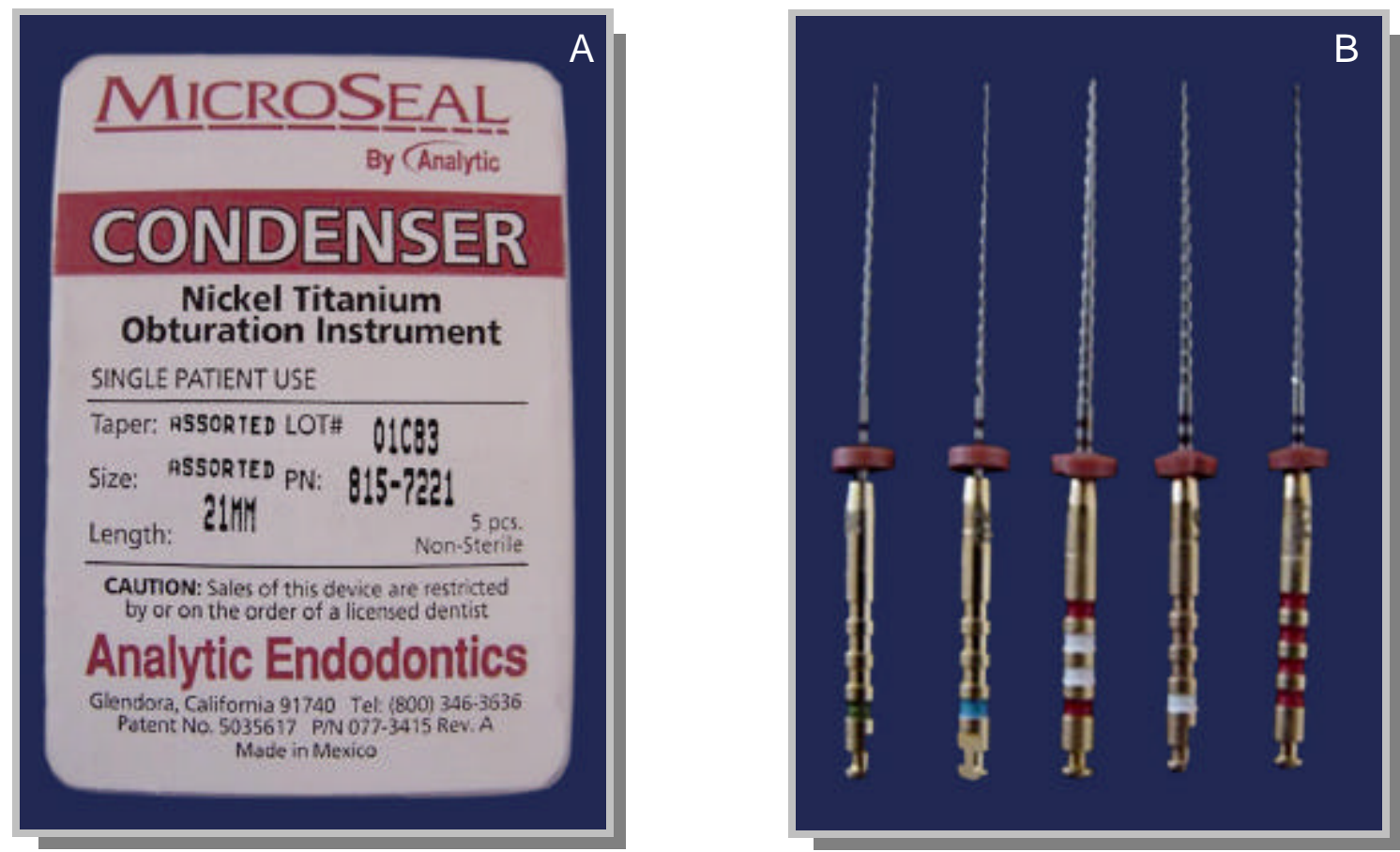

FIGURA 8 - A e B - Compactadores de níquel-titânio do sistema Microseal 


\section{2 - Metodologia}

\subsection{1 - Seleção dos dentes}

Para a realização deste estudo, foram selecionados dentes incisivos inferiores humanos extraídos, com raízes completamente formadas, que após a extração foram mantidos em solução de formaldeído ${ }^{(a)}$ a $10 \%$.

Os tecidos moles e cálculos aderidos à raiz foram eliminados com 0 auxílio de curetas periodontais de Gracey $n^{\circ} \quad 5 / 6^{(b)}$ e, posteriormente, os dentes foram armazenados em solução fisiológica ${ }^{(\mathrm{c})}$.

Em seguida, os dentes foram radiografados nos sentidos vestíbulo-lingual e mésio-distal. Quando se constatava a presença de dois canais, calcificações, canais curvos ou evidências de realização de tratamento endodôntico anterior, os mesmos eram descartados.

Assim, para este trabalho, foram utilizados 106 dentes, com comprimento entre 19 e 22 milímetros e com canais retos e únicos.

\subsection{2 - Preparo biomecânico dos canais radiculares}

A abertura coronária foi realizada com pontas diamantadas esféricas número $1013^{(\mathrm{d})}$ e complementada com brocas de $\mathrm{Batt}^{(\mathrm{e})}$ de calibre $^{(2)}$ compatível com o tamanho da câmara pulpar.

A instrumentação do canal foi realizada com limas tipo Kerr ${ }^{(e)}$ de 21 e 25 milímetros, utilizando-se a técnica de instrumentação escalonada regressiva, preconizada por WEINE ${ }^{147}$.

O comprimento do dente foi estabelecido através da introdução de uma lima no 10 contendo um limitador de penetração de borracha no canal radicular. Quando se percebia a extremidade da lima no nível do forame

\footnotetext{
(a) Farma-Ticli Indústria Farmacêutica - São Paulo - SP - Brasil

(b) S.S. White Artigos Dentários LTDA - Juiz de Fora - MG - Brasil

(c) Darrow Laboratórios S.A. - Rio de Janeiro - RJ - Brasil

(d) Kg Sorensen Indústria e Comércio LTDA - Barueri - São Paulo - Brasil

(e) Maillefer Instruments - Ballaigues - Suíça
} 
apical, o limitador de penetração era nivelado na borda incisal do dente e o comprimento anotado. Em seguida, procedeu-se à padronização do forame apical instrumentando-se o canal, nesse limite, até a lima $n^{\circ} 25$. Não foram utilizados dentes que possuíam o forame apical com calibre maior que o da lima no 25 .

A seguir, o comprimento de trabalho foi determinado subtraindo-se um milímetro do comprimento total do dente. Os canais foram instrumentados nesse limite para a confecção do batente apical até a lima № 40, caracterizando-se 0 instrumento de memória. Em seguida, foi realizada a instrumentação regressiva dos canais radiculares até a lima $n^{\circ} 60$, passando a cada troca de lima o instrumento de memória, no comprimento de trabalho.

A cada troca de instrumento realizou-se uma copiosa irrigação com solução fisiológica com auxílio de uma seringa Luer-Look ${ }^{(a)}$ e uma cânula de irrigação nํㅜ 30X4 $4^{(\mathrm{b})}$.

Após a instrumentação dos canais radiculares, uma lima no 25 foi introduzida no comprimento total do dente para realizar a limpeza do forame apical. Em seguida, os canais radiculares foram irrigados com solução fisiológica e a mesma foi aspirada com cânulas ${ }^{(b)}$.

\subsection{3 - Seleção do cone principal}

Na seqüência, realizou-se a prova dos cones nos canais dos grupos da condensação lateral, Microseal e System B, pois as demais técnicas não utilizam cone principal para a obturação dos canais radiculares.

Nos dentes dos grupos da condensação lateral e do sistema Microseal foram utilizados cones de guta-percha estandardizados $n^{\circ} 40$, $\operatorname{Tanari}^{(\mathrm{c})} \mathrm{e}$ Microseal $^{(\mathrm{d})}$, respectivamente. Nos dentes do grupo do System B foram utilizados cones de guta-percha não estandardizados Autofit ${ }^{(\mathrm{d})}$, no tamanho FM. O cone FM era introduzido em uma régua calibradora ${ }^{(e)}$ e regulado no tamanho 40 (Figura 3C).

\footnotetext{
(a) Duflex - S.S. White Artigos Dentários LTDA - Rio de Janeiro - RJ - Brasil

(b) BD - Becton Dickinson Indústrias Cirúrgicas LTDA - Rio de Janeiro - RJ - Brasil

(c) Tanariman Industrial LTDA - Manacapuru - AM - Brasil

(d) Analytic Endodontics - Sybron Endo - Califórnia - USA

(e) Maillefer Instruments - Ballaigues - Suíça
} 
Nos três grupos, o cone era considerado adequado quando penetrava no comprimento de trabalho e apresentava uma leve resistência, ou seja, um pequeno travamento durante sua remoção. Nos dentes em que o cone não penetrava em toda a extensão de instrumentação, selecionava-se um cone de gutapercha de menor calibre até que se ajustasse ao comprimento de trabalho. Nos casos em que o cone não apresentava resistência durante a sua remoção, a extremidade do mesmo era seccionada com uma lâmina afiada de bisturi $n=11^{(\mathrm{a})}$ ou escolhia-se um cone de maior calibre a fim de se obter o travamento desejado.

Após a prova do cone nos dentes dos três grupos (condensação lateral, System B e Microseal), os mesmos foram removidos dos canais radiculares, presos a uma folha de papel sulfite com pedaços de fita adesiva e devidamente identificados.

Em seguida, realizou-se a prova do condensador $\mathrm{FM}^{(\mathrm{b})}$ nos dentes do grupo System B. O condensador FM deveria penetrar no canal radicular cinco milímetros aquém do comprimento de trabalho para que, durante a obturação dos canais radiculares, o mesmo atingisse a profundidade adequada. A penetração correta do condensador foi confirmada em todos os dentes desse grupo.

\subsection{4 - Impermeabilização dos dentes}

Para facilitar o manuseio dos dentes, introduziu-se na abertura coronária de cada dente um palito de madeira ${ }^{(\mathrm{c})}$.

Em seguida, 100 dentes foram impermeabilizados nas superfícies externas da coroa e da raiz, exceto nas proximidades do forame apical, numa extensão média de um milímetro ao redor do mesmo. A impermeabilização foi realizada, inicialmente, com uma camada de Araldite de presa lenta ${ }^{(\mathrm{d})}$, seguida pela aplicação de duas camadas de esmalte vermelho para unhas ${ }^{(e)}$.

\footnotetext{
(a) BD - Becton Dickinson Indústrias Cirúrgicas LTDA - Rio de Janeiro - RJ - Brasil

(b) Analytic Endodontics - Sybron Endo - Califórnia - USA

(c) Rela S.A. Indústria e Comércio - Nova Ponte - MG - Brasil

(d) Brascola LTDA - Indústria Brasileira - São Bernardo do Campo - SP - Brasil

(e) Risqué - Niasi S.A. - Taboão da Serra - SP - Brasil
} 
Esperou-se um intervalo de 24 horas entre a aplicação de cada camada impermeabilizadora, permanecendo o dente em meio seco durante esse período, fixado em uma lâmina de cera utilidade ${ }^{(a)}$ (Figura 9).

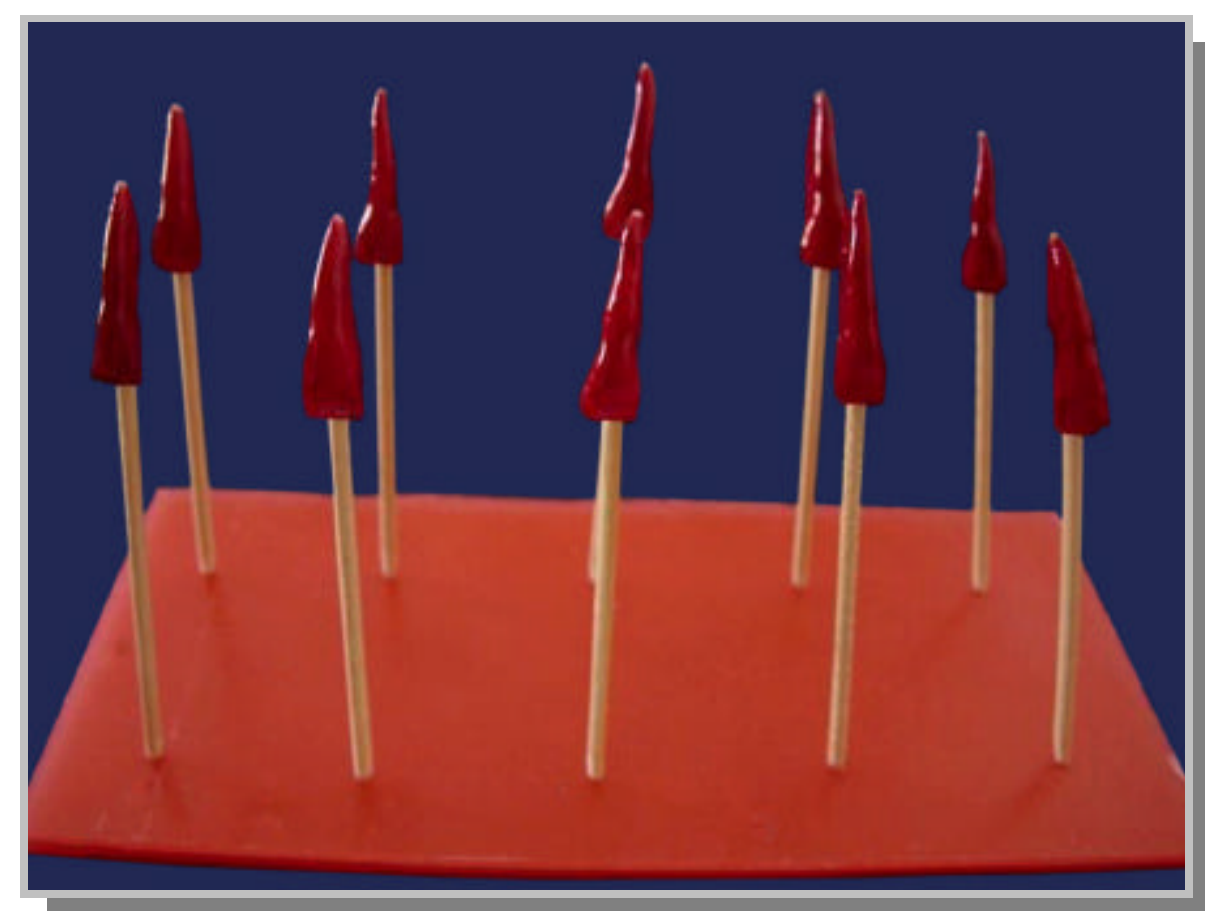

FIGURA 9 - Dentes impermeabilizados, fixados em uma lâmina de cera

Mais seis dentes foram utilizados, sendo três dentes como controle negativo e três como controle positivo. Os dentes do controle positivo foram impermeabilizados da mesma maneira que a descrita anteriormente, enquanto nos dentes do controle negativo, incluía-se o forame apical na impermeabilização.

Posteriormente, os palitos de madeira foram removidos das aberturas coronárias e os dentes foram armazenados em solução fisiológica para que fossem novamente hidratados.

(a) Polidental Indústria e Comércio LTDA - São Paulo - SP - Brasil 
4.2.5 - Aplicação do EDTA e secagem dos canais dos canais radiculares

Previamente à obturação, os canais radiculares foram irrigados com solução de EDTA a $17 \%$ (a), por 3 minutos, para remoção da "smear layer", seguida pela irrigação com solução fisiológica. Em seguida, o excesso de líquido dos canais foi aspirado através de uma cânula e os mesmos foram secos com pontas de papel absorvente $n \cong 40$ Tanari $^{(b)}$.

\subsection{6 - Obturação dos canais radiculares}

Dos 106 incisivos inferiores, seis foram utilizados nos grupos controles (positivo e negativo) e cem nos grupos experimentais, divididos em cinco grupos de vinte elementos cada, de acordo com as técnicas de obturação propostas (Tabela 1).

TABELA 1 - Distribuição dos dentes de acordo com os grupos controles e experimentais

106 incisivos inferiores

\begin{tabular}{c|c|c|c|c|c|c}
\hline $\begin{array}{c}\text { Grupos controles } \\
6 \text { dentes }\end{array}$ & \multicolumn{5}{|c}{$\begin{array}{c}\text { Grupos experimentais } \\
100 \text { dentes }\end{array}$} \\
\hline Positivo & Negativo & Condens. Lateral & System B & Ultrafil & JS Quick-Fill & Microseal \\
\hline 3 & 3 & 20 & 20 & 20 & 20 & 20 \\
\hline
\end{tabular}

Os dentes dos grupos controles positivo e negativo não foram obturados.

(a) Odahcam Dentsply Indústria e Comércio LTDA - Petrópolis - RJ - Brasil

(b) Tanariman Industrial LTDA - Manacapuru - AM - Brasil 
Em todos os grupos experimentais, os dentes foram presos em uma morsa ${ }^{(a)}$ para que permanecessem imóveis durante a obturação (Figura 10).

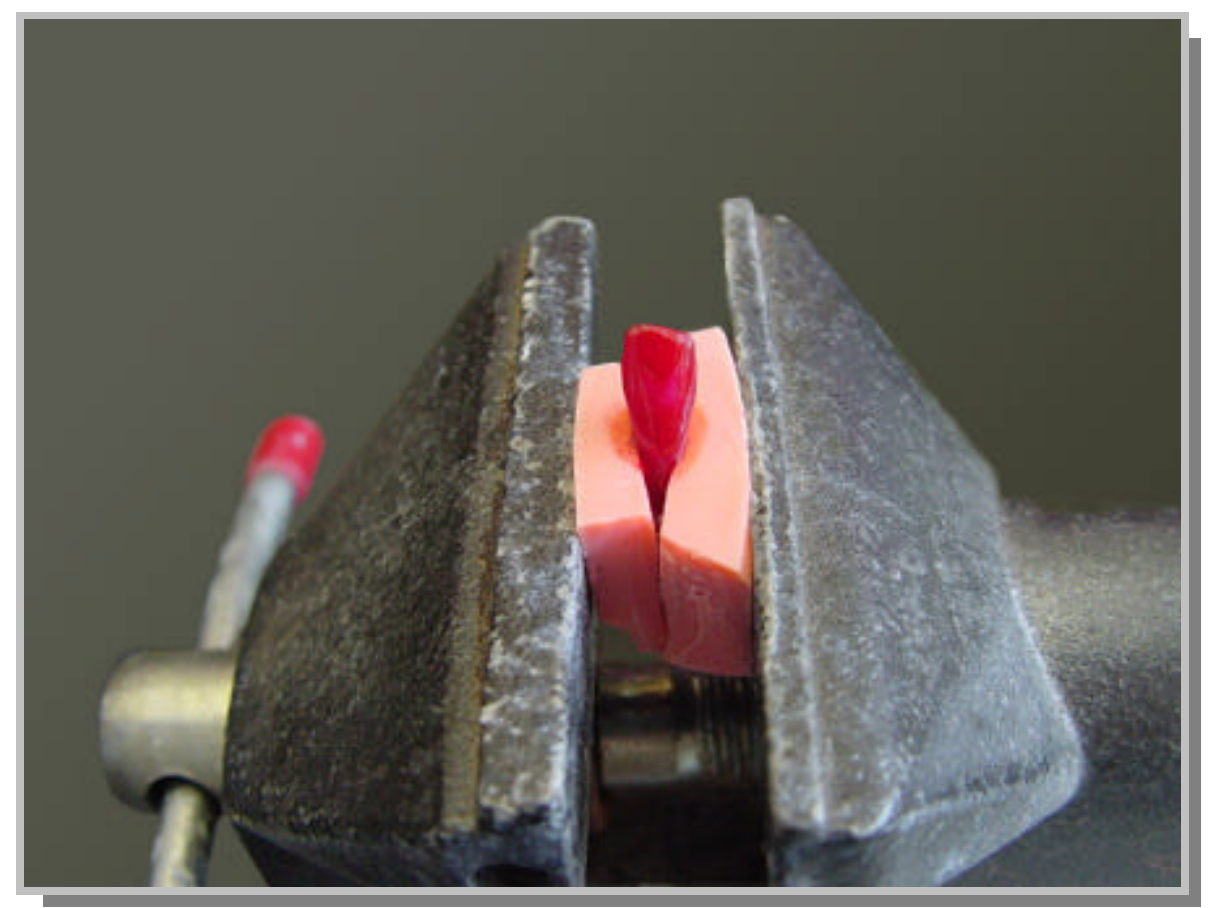

FIGURA 10 - Incisivo inferior preso na morsa

Em seguida, o cimento Endofill ${ }^{(b)}$ foi manipulado na proporção de 0,5 grama de pó para 5 gotas de líquido, já que nessa proporção ele apresentava a consistência de fio quando a espátula era levantada por cerca de dois centímetros, consistência esta recomendada pelo fabricante ${ }^{(\mathrm{c})}$.

Um passo comum para todos os grupos experimentais foi a aplicação do cimento obturador nas paredes dos canais radiculares com o auxílio de uma lima tipo Kerr no 40, no comprimento de trabalho (técnica clássica), para proceder-se então à obturação.

(a) Somar Indústria e Comércio - Joinvile - SC - Brasil

(b) Dentsply Indústria e Comércio LTDA - Petrópolis - RJ - Brasil

(c) ENDOFILL: cimento endodôntico. Rio de Janeiro, Dentsply Herpo / Bula do Material / 


\subsubsection{1 - Técnica da Condensação Lateral}

A técnica da condensação lateral foi realizada de acordo com BRAMANTE; BERBERT; PICCINO ${ }^{18}$. Após o assentamento do cone de guta-percha principal, previamente selecionado, os espaços na obturação para a introdução dos cones acessórios de guta-percha foram abertos com uma lima tipo Kerr nํㅜ 30, de 21 milímetros de comprimento.

Para realizar a condensação lateral, envolvia-se a lima com cimento e a mesma era introduzida no canal radicular o mais próximo possível do comprimento de trabalho. Em seguida, eram realizados movimentos de lateralidade e a mesma era removida no sentido anti-horário. Imediatamente após a remoção da lima, introduzia-se no espaço deixado um cone de guta-percha acessório B7 Tanari $^{(a)}$. Esse procedimento era repetido até que a lima tipo Kerr não penetrasse mais no canal radicular.

Na seqüência, realizava-se o corte da obturação, no nível da embocadura do canal, com um condensador $^{(b)}$ aquecido e, em seguida, a condensação vertical, utilizando um condensador frio.

\subsubsection{2 - Técnica da Onda Contínua de Condensação realizada com o System B}

A obturação dos canais radiculares com o System B foi realizada de acordo com o idealizador da técnica ${ }^{22,23}$ e com as recomendações fornecidas pelo fabricante ${ }^{137}$.

A primeira fase da obturação com o System B, denominada "Downpack", promove a obturação do terço apical do canal radicular e foi realizada da seguinte maneira:

과 O aparelho System B foi ligado e regulado no modo "touch", potência 10 e temperatura $200^{\circ} \mathrm{C}$.

\footnotetext{
(a) Tanariman Industrial LTDA - Manacapuru - AM - Brasil

(b) Odous Instrumentos LTDA - Belo Horizonte - MG - Brasil
} 
จ $\mathrm{O}$ cone de guta-percha principal FM, previamente selecionado, foi assentado no canal radicular.

จู A profundidade de inserção do condensador FM foi demarcada no mesmo com um cursor de borracha, cinco milímetros aquém do comprimento de trabalho.

과 Com o condensador FM aquecido, cortou-se o excesso do cone principal na embocadura do canal.

그 $\mathrm{O}$ condensador FM do System B frio foi levado em contato com a gutapercha na embocadura do canal. A chave de aquecimento foi ligada e o condensador introduzido em um movimento único, em direção apical, até que o cursor de borracha atingisse aproximadamente três milímetros aquém do ponto de referência, demarcado previamente no condensador.

จ A chave de aquecimento foi desligada e o condensador continuou sendo movimentado em direção apical, até que o cursor atingisse o ponto de referência. O condensador foi mantido sob pressão nessa posição durante 10 segundos.

과 $A$ seguir, a chave de aquecimento foi acionada por um segundo e desligada. Esperou-se um segundo e o condensador foi removido.

A segunda fase da obturação com o System B, denominada "Backfill", promove a obturação dos terços médio e cervical do canal e foi realizada da seguinte forma:

ㄱํ O aparelho System B foi regulado no modo "touch", potência $10 \mathrm{e}$ temperatura $100^{\circ} \mathrm{C}$.

ㄱ․ Um cone principal de guta-percha FM foi ajustado e assentado nos terços médio e cervical do canal, pois o terço apical já tinha sido obturado na fase anterior (“Downpack”).

२ู $\mathrm{O}$ condensador FM frio foi introduzido na embocadura do canal. A chave de aquecimento foi ligada por 0,5 segundo e desligada. $O$ condensador foi introduzido firmemente em direção apical, na metade da profundidade do espaço "Backfill", e mantido nessa posição por 3 a 
5 segundos, realizando pressão apical. A seguir, o condensador foi girado cuidadosamente no sentido anti-horário e removido do canal.

จู. Outro cone principal FM foi cimentado no espaço cervical deixado pelo condensador.

ㄱํ $\mathrm{O}$ aparelho System B foi regulado no modo "touch", potência $10 \mathrm{e}$ temperatura $200^{\circ} \mathrm{C}$.

7ु $A$ chave de aquecimento foi ligada por dois segundos e o excesso do cone principal cortado, na cervical, sem realizar pressão apical.

จู A guta-percha foi condensada verticalmente com um condensador manual.

4.2.6.3 - Técnica da guta-percha termoplastificada injetável realizada com o sistema Ultrafil

A obturação dos canais radiculares com o sistema Ultrafil seguiu as recomendações fornecidas pelo fabricante ${ }^{143}$.

2ู $\mathrm{O}$ aquecedor do sistema Ultrafil foi ligado durante 10 minutos para que atingisse a temperatura adequada. A cânula azul, contendo gutapercha de consistência firme ("firm set"), foi colocada no aquecedor durante três minutos.

จู A cânula pré-aquecida foi inserida na seringa do sistema Ultrafil. Em seguida, um procedimento de pressão e soltura do gatilho (click-click esperar 3 segundos) foi repetido até que a guta-percha fluísse através da ponta da cânula. Limpou-se a guta-percha extravasada na extremidade da cânula com uma gaze e a seringa contendo a cânula foi recolocada no aquecedor.

จู Para a obturação, inseriu-se a cânula nos canais radiculares seis milímetros aquém do comprimento de trabalho. A guta-percha foi injetada no canal, pressionando-se e soltando-se o gatilho da seringa várias vezes.

2. Quando o terço apical encontrava-se obturado, a cânula começava a recuar. A partir desse momento, era lentamente removida e a guta- 
percha injetada nos demais terços do canal, da mesma maneira que no terço apical, até que atingisse a embocadura do canal.

과 $A$ seguir, realizava-se a condensação vertical com condensadores manuais.

4.2.6.4 - Técnica da guta-percha termoplastificada mecanicamente realizada com o sistema JS Quick-Fill

A obturação dos canais radiculares com o sistema JS QuickFill, da mesma forma que a dos anteriores, seguiu as recomendações fornecidas pelo fabricante ${ }^{73}$.

과 Selecionou-se um compactador recoberto por guta-percha JS Quick-Fill número 30. O cursor do compactador foi ajustado no comprimento de trabalho e o compactador colocado no contra-ângulo do micromotor elétrico NT Matic II ${ }^{(\mathrm{a})}$.

과 $\mathrm{O}$ compactador foi inserido no canal radicular, sem ser acionado, até que uma leve resistência fosse sentida. A seguir, o compactador foi acionado no sentido horário, na velocidade de 6000 rpm e, quando a plastificação da guta-percha foi notada, o mesmo foi inserido em direção apical, com leve pressão, até atingir o comprimento de trabalho previamente definido pelo cursor.

과 Ao atingir o comprimento desejado, o compactador foi removido lentamente do canal, em rotação horária, na mesma velocidade, aplicando-se uma leve pressão contra uma das paredes do canal. A rotação não foi interrompida até que o compactador estivesse totalmente fora do canal radicular.

จู $\mathrm{Na}$ seqüência, realizou-se a condensação vertical com condensadores manuais.

(a) Analytic Endodontics - Sybron Endo - Califórnia - USA 
4.2.6.5 - Técnica da guta-percha termoplastificada associada a um cone principal realizada com o sistema Microseal

Para a realização das obturações dos canais radiculares com o sistema Microseal, foram seguidas as recomendações do fabricante ${ }^{39}$.

Após o assentamento do cone de guta-percha principal Microflow, a obturação foi realizada da seguinte maneira:

과 Quando o aquecedor Microseal foi ligado, acenderam-se as luzes verde e vermelha. Esperou-se a luz vermelha apagar.

จู Uma lima no 30 foi inserida no canal, ao lado do cone principal, três milímetros aquém do comprimento de trabalho e removida, deixando um espaço aberto.

2จ Um cartucho de guta-percha Microflow foi rosqueado na seringa Microflow e o conjunto foi levado ao aquecedor Microseal durante 15 segundos.

จู Um compactador Microseal de número 45 e conicidade 0,04 foi adaptado no contra-ângulo do micromotor elétrico NT Matic II. O micromotor foi regulado na velocidade de $6000 \mathrm{rpm}$.

과 $A$ seringa contendo a guta-percha plastificada foi removida do aquecedor. O compactador Microseal foi introduzido imediatamente no cartucho da guta-percha aquecida, na profundidade da sua porção com ranhuras. Em seguida, o compactador foi removido do cartucho da guta-percha aquecida. À medida que o compactador era removido, o êmbolo da seringa era apertado para que o compactador ficasse coberto por uma camada uniforme de guta-percha.

과 $\mathrm{O}$ compactador revestido por guta-percha foi inserido imediatamente no canal radicular, no espaço previamente criado pela lima $n^{\circ} 30$, três milímetros aquém do comprimento de trabalho, sem acionar o micromotor.

과 $\mathrm{O}$ micromotor foi acionado na velocidade de $6000 \mathrm{rpm}$, no sentido horário, sem aplicar qualquer pressão apical, mas resistindo ao movimento de saída do canal que o compactador exercia. $O$ 
compactador foi mantido nessa posição durante dois segundos e, em seguida, foi removido lentamente, em rotação horária, na mesma velocidade, exercendo leve pressão em uma das paredes do canal. A rotação não foi interrompida até que o compactador estivesse totalmente removido do canal radicular.

과 Após a remoção do compactador do canal radicular, a lima ํo 30 foi novamente inserida no centro da obturação, três milímetros aquém do comprimento de trabalho.

จูป Uma nova porção de guta-percha Microflow, previamente aquecida, foi colocada no compactador e a técnica de obturação descrita realizada novamente.

२ Em seguida, realizou-se condensação vertical com condensadores manuais.

\subsection{7 - Selamento provisório}

Após a obturação dos canais radiculares, em todos os grupos, a câmara pulpar dos dentes foi limpa com uma bolinha de algodão embebida em álcool $^{(\mathrm{a})}$. As aberturas coronárias foram seladas com cimento temporário Cimpat $^{(\mathrm{b})} \mathrm{e}$ impermeabilizadas com cera utilidade derretida.

\subsection{8 - Imersão dos dentes no corante e seccionamento longitudinal}

Imediatamente após a impermeabilização com cera, todos os dentes foram imersos em solução aquosa de azul de metileno a $2 \%$, ficando os elementos de cada grupo em recipientes plásticos distintos, previamente identificados. Os dentes permaneceram na solução corante durante 72 horas, a 37ํㅡ, armazenados em estufa ${ }^{(\mathrm{c})}$. Após esse período, foram lavados em água corrente por 12 horas e raspados com um instrumento tipo Lecron para remoção da

\footnotetext{
(a) Copersucar Indústria Brasileira - São Paulo - SP - Brasil

(b) Septodont - DFL - Indústria e Comércio LTDA - Barcelona - Espanha

(c) Equipamentos de Laboratório - São Paulo - SP - Brasil
} 
camada impermeabilizadora da superfície externa do dente.

A seguir, os dentes foram radiografados nos sentidos vestíbulolingual e mésio-distal para averiguação da qualidade da obturação.

$\mathrm{Na}$ seqüência, com um disco diamantado dupla face ${ }^{(a)}$, foram confeccionados dois sulcos longitudinais na superfície externa do dente, um na face vestibular e o outro na lingual, até que se aproximassem da obturação. Com o auxílio de um cinzel, o dente foi fraturado no seu longo eixo, obtendo-se duas hemipartes para avaliação da infiltração apical do corante.

\subsection{9 - Avaliação da infiltração apical}

A avaliação da infiltração apical foi realizada através da Técnica da Planimetria, com auxílio de um estereomicroscópio ${ }^{(b)}$, munido de uma objetiva com aumento de $4 x$ e uma ocular graduada.

A infiltração apical foi medida em uma das hemi-partes do dente. A hemi-parte selecionada foi presa com cera utilidade em uma lâmina de vidro $^{(\mathrm{c})}$ para microscopia para facilitar a visualização da infiltração no estereomicroscópio, utilizando-se de luz artificial refletida.

A infiltração foi avaliada na interface entre o material obturador e a parede dentinária, considerando-se para leitura a interface que apresentava maior infiltração de corante. Mediu-se desde a ponta do cone principal (grupos da condensação lateral, System B e sistema Microseal) ou da extremidade mais apical da guta-percha (sistemas Ultrafil e JS Quick-Fill) até a porção mais coronária do corante.

A leitura da infiltração foi realizada por dois examinadores sendo, a seguir, os valores transformados em milímetros e a média aritmética destes calculada. Posteriormente, as medidas foram tabuladas e submetidas à análise estatística, através dos testes de Kruskal-Wallis e de Dunn, com nível de significância de $5 \%$.

\footnotetext{
(a) KG Soresen Indústria e Comércio LTDA - Barueri - SP - Brasil

(b) Bausch \& Lomb - USA

(c) Perfecta - Indústria Brasileira
} 


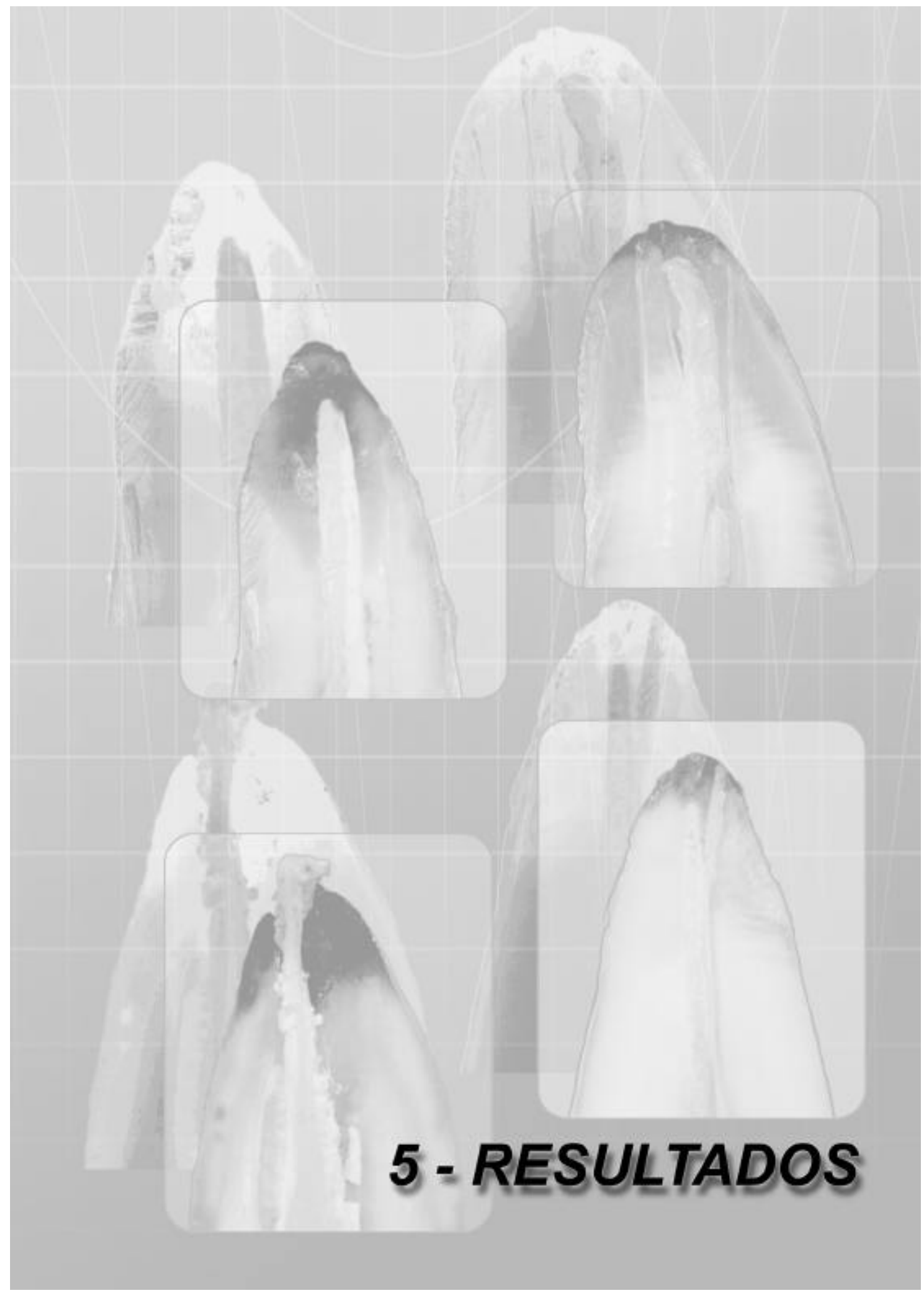




\section{5 - RESULTADOS}

Os dentes do grupo controle negativo não apresentaram infiltração do corante azul de metileno no canal radicular, comprovando a qualidade da impermeabilização externa dos dentes com araldite e esmalte para unhas.

Os dentes do grupo controle positivo apresentaram completa marcação das paredes do canal radicular pelo corante azul de metileno, evidenciando a eficácia da metodologia empregada.

A infiltração apical, evidenciada nos dentes dos grupos experimentais, está apresentada na Tabela 2.

TABELA 2 - Infiltração apical (em milímetros) do corante azul de metileno nos dentes avaliados, segundo as técnicas obturadoras utilizadas

\begin{tabular}{c|c|c|c|c|c}
\hline & \multicolumn{5}{|c}{ GRUPOS EXPERIMENTAIS } \\
\hline Dentes & Condensação Lateral & System B & Ultrafil & JS Quick-Fill & Microseal \\
\hline 1 & 1,22 & 2,19 & 2,68 & 0,00 & 0,28 \\
\hline 2 & 2,56 & 0,24 & 8,54 & 5,49 & 0,39 \\
\hline 3 & 2,19 & 0,67 & 1,64 & 0,61 & 0,12 \\
\hline 4 & 0,67 & 2,99 & 3,05 & 7,56 & 0,79 \\
\hline 5 & 2,68 & 0,10 & 7,32 & 2,44 & 0,00 \\
\hline 6 & 2,56 & 0,85 & 0,24 & 6,10 & 0,61 \\
\hline 7 & 8,78 & 0,67 & 0,00 & 0,67 & 0,06 \\
\hline 8 & 1,22 & 0,82 & 2,99 & 1,71 & 0,91 \\
\hline 9 & 2,56 & 0,91 & 0,55 & 0,73 & 0,36 \\
\hline 10 & 3,05 & 0,82 & 0,18 & 6,04 & 1,70 \\
\hline 11 & 3,05 & 0,79 & 0,79 & 0,43 & 0,00 \\
\hline 12 & 3,54 & 0,00 & 2,80 & 2,32 & 0,12 \\
\hline 13 & 0,49 & 0,55 & 2,68 & 1,40 & 0,36 \\
\hline 14 & 2,01 & 1,00 & 0,73 & 1,16 & 0,73 \\
\hline 15 & 4,76 & 1,10 & 1,79 & 2,20 & 0,18 \\
\hline 16 & 4,63 & 0,49 & 0,49 & 4,39 & 0,61 \\
\hline 17 & 3,17 & 0,79 & 5,36 & 0,98 & 0,97 \\
\hline 18 & 2,80 & 1,22 & 0,49 & 2,07 & 1,15 \\
\hline 19 & 1,10 & 0,00 & 2,38 & 0,00 & 0,00 \\
\hline 20 & 3,11 & 0,22 & 3,66 & 0,49 & 0,00 \\
\hline
\end{tabular}


A partir da infiltração de cada dente, obteve-se a média e o desvio-padrão da infiltração apical de corante para cada grupo avaliado (Tabela 3 e Figura 11).

TABELA 3 - Valores médios (em milímetros) da infiltração apical do corante azul de metileno, $(\bar{X})$, desvio-padrão $(\mathrm{dp})$ e número de amostras $(\mathrm{N})$ dos grupos avaliados

\begin{tabular}{c|c|c|c}
\hline GRUPOS & MÉDIA (X) & DESVIO-PADRÃO (dp) & AMOSTRAS (N) \\
\hline Condensação Lateral & 2,81 & 1,82 & 20 \\
\hline System B & 0,82 & 0,73 & 20 \\
\hline Ultrafil & 2,42 & 2,36 & 20 \\
\hline JS Quick-Fill & 2,34 & 2,30 & 20 \\
\hline Microseal & 0,47 & 0,46 & 20 \\
\hline
\end{tabular}

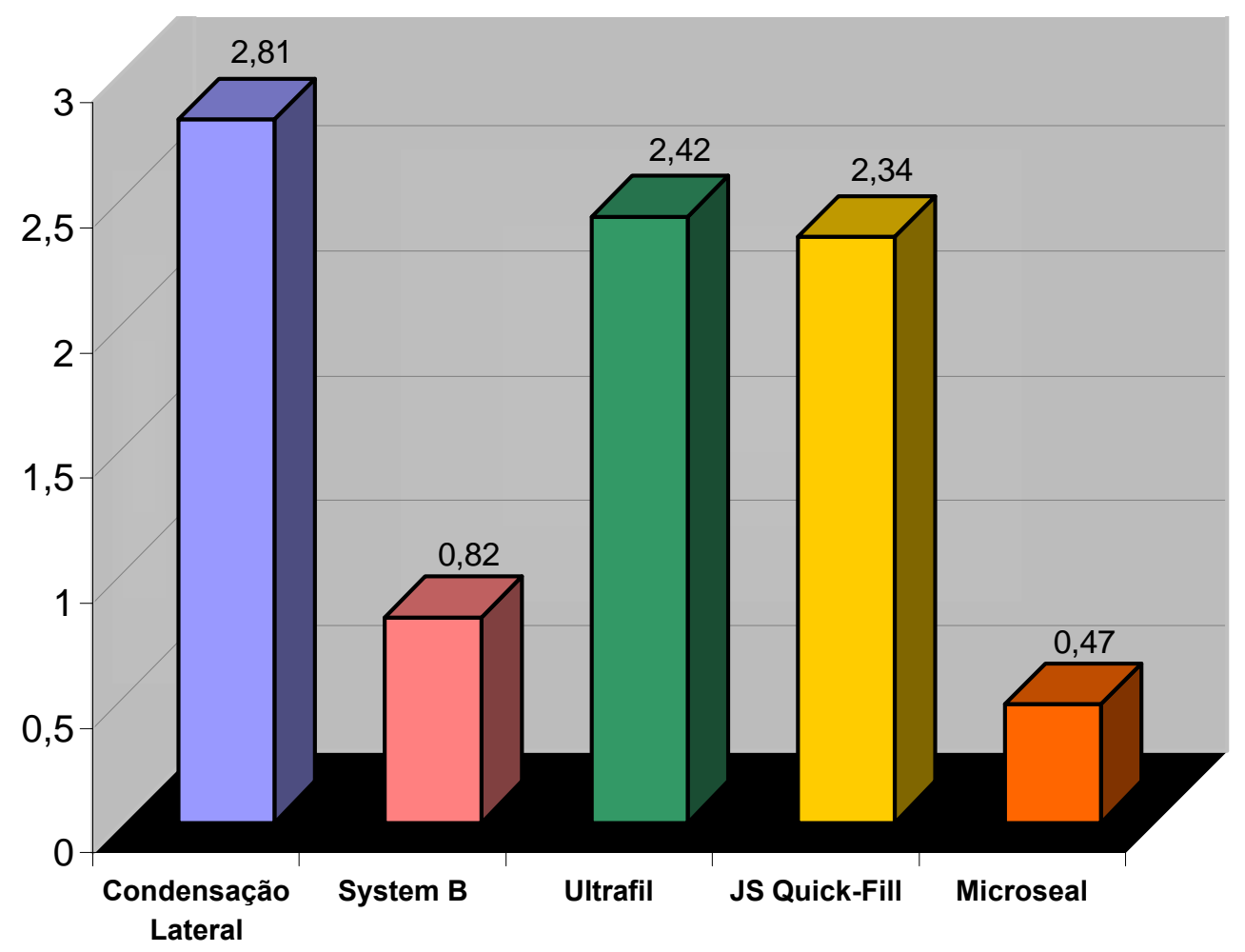

FIGURA 11 - Gráfico da infiltração apical média (em milímetros) dos grupos avaliados 
Devido aos resultados obtidos não terem passado pelo teste de normalidade e também não haver homogeneidade de variâncias, optou-se por executar o teste estatístico não paramétrico de Kruskal-Wallis. Nesse teste, detectou-se que existia diferença significante na infiltração apical apresentada pelos diferentes grupos $(H=32,45, p<0,001)$.

Em seguida, realizou-se o teste estatístico de Dunn para identificar entre quais grupos essa diferença se apresentava significativa, com nível de significância de 5\% (Tabela 4).

TABELA 4 - Comparação das médias de infiltração apical entre os grupos, pelo teste estatístico de Dunn, com nível de significância de 5\%

\begin{tabular}{c|c}
\hline COMPARAÇÃO & DIFERENÇA \\
\hline Condensação Lateral X Microseal & $2,34^{*}$ \\
\hline Condensação Lateral X System B & $1,99^{*}$ \\
\hline Condensação Lateral X JS Quick-Fill & $0,47^{\text {n.s. }}$ \\
\hline Condensação Lateral X Ultrafil & $0,39^{\text {n.s. }}$ \\
\hline Ultrafil X Microseal & $1,95^{*}$ \\
\hline Ultrafil X System B & $1,60^{\text {n.s. }}$ \\
\hline Ultrafil X JS Quick-Fill & $0,08^{\text {n.s. }}$ \\
\hline JS Quick-Fill X Microseal & $1,87^{*}$ \\
\hline JS Quick-Fill X System B & $1,52^{\text {n.s. }}$ \\
\hline System B X Microseal & $0,35^{\text {n.s. }}$ \\
\hline
\end{tabular}

* diferença estatisticamente significante $(p<0,05)$

n.s. diferença estatisticamente não significante $(p<0,05)$ 


\section{1 - Técnica da Condensação Lateral}

A técnica da condensação lateral apresentou a maior média de infiltração apical de corante $(2,81 \mathrm{~mm})$ quando comparada aos demais grupos avaliados, diferindo-se estatisticamente dos sistemas Microseal $(0,47 \mathrm{~mm})$ e System B $(0,82 \mathrm{~mm})$. Não houve diferença estatisticamente significante entre a técnica da condensação lateral e os sistemas Ultrafil $(2,42 \mathrm{~mm})$ e JS Quick-Fill $(2,34 \mathrm{~mm})$ (Tabela 4).

Entre os espécimes obturados pela técnica da condensação lateral, a menor infiltração apical encontrada foi de 0,49 $\mathrm{mm}$ e a maior de 8,78 $\mathrm{mm}$ (Tabela 2). Dos dentes, 10\% apresentaram infiltração apical de corante menor ou igual a $1 \mathrm{~mm}, 20 \%$ apresentaram infiltração apical entre 1,1 e $2 \mathrm{~mm}, 30 \%$ apresentaram infiltração apical entre 2,1 e 3 mm e 40\% apresentaram infiltração apical superior a $3 \mathrm{~mm}$ (Figura 12).

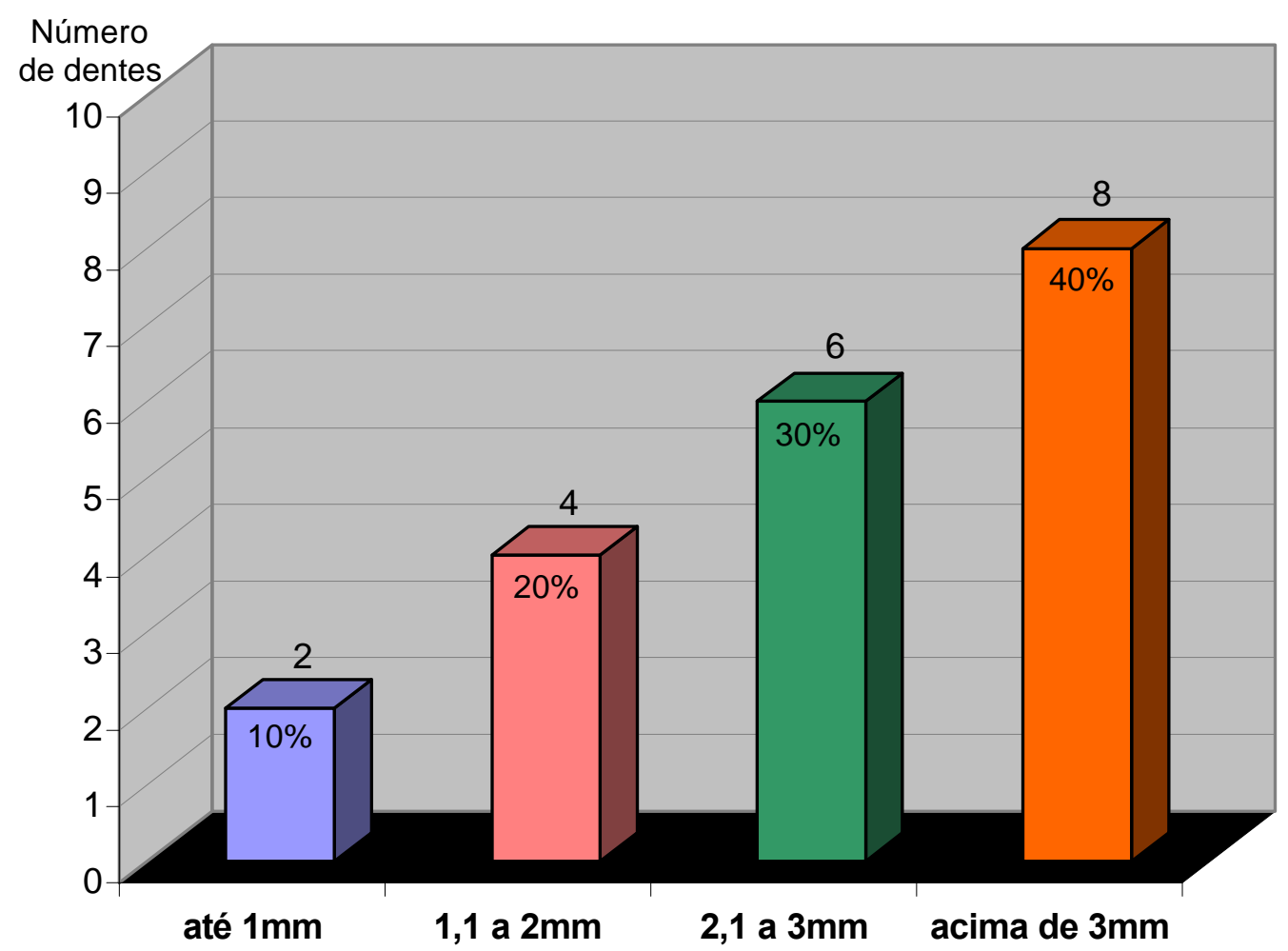

FIGURA 12 - Gráfico da distribuição dos dentes do grupo da Condensação Lateral em função da extensão em que as infiltrações ocorreram 

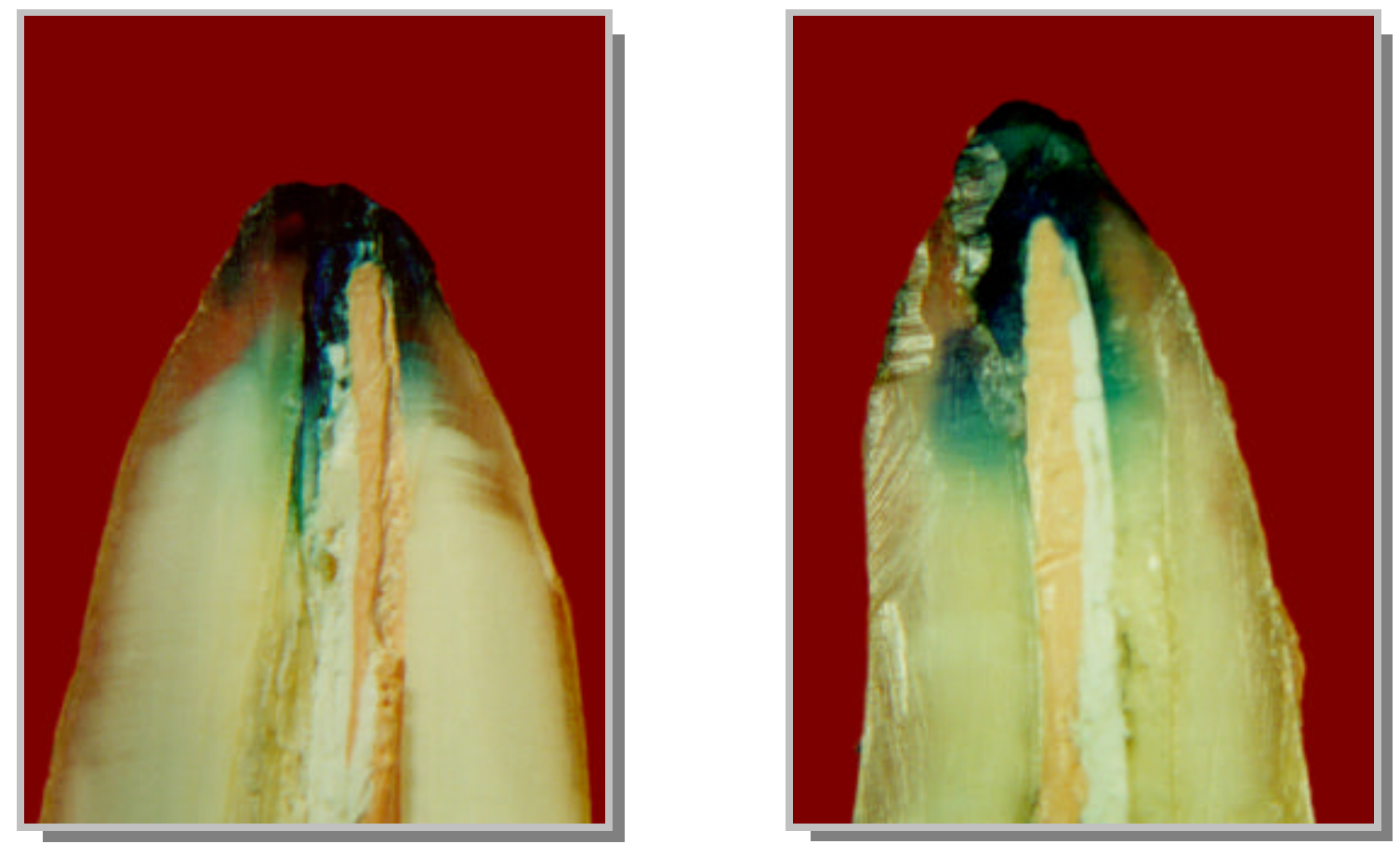

FIGURA 13 - Infiltração apical do corante azul de metileno observada nos espécimes do grupo da Condensação Lateral

\section{2 - System B}

O System B apresentou infiltração apical média de corante de 0,82 $\mathrm{mm}$, diferenciando-se estatisticamente da técnica da condensação lateral, a qual apresentou infiltração média de $2,81 \mathrm{~mm}$. Não houve diferença estatisticamente significante entre o System B e os demais sistemas avaliados: Microseal, Ultrafil e JS Quick-Fill, os quais apresentaram médias de 0,47 mm, 2,42 mm e 2,34 mm, respectivamente (Tabela 4$)$.

Entre os espécimes obturados pelo System B, o menor resultado encontrado foi de $0 \mathrm{~mm}$ (sem infiltração) e o maior de 2,99 mm (Tabela 2). Dos dentes, 80\% apresentaram infiltração apical de corante menor ou igual a $1 \mathrm{~mm}$, $10 \%$ apresentaram infiltração apical entre 1,1 e $2 \mathrm{~mm}$ e 10\% apresentaram infiltração apical entre 2,1 e 3 mm (Figura 14). 


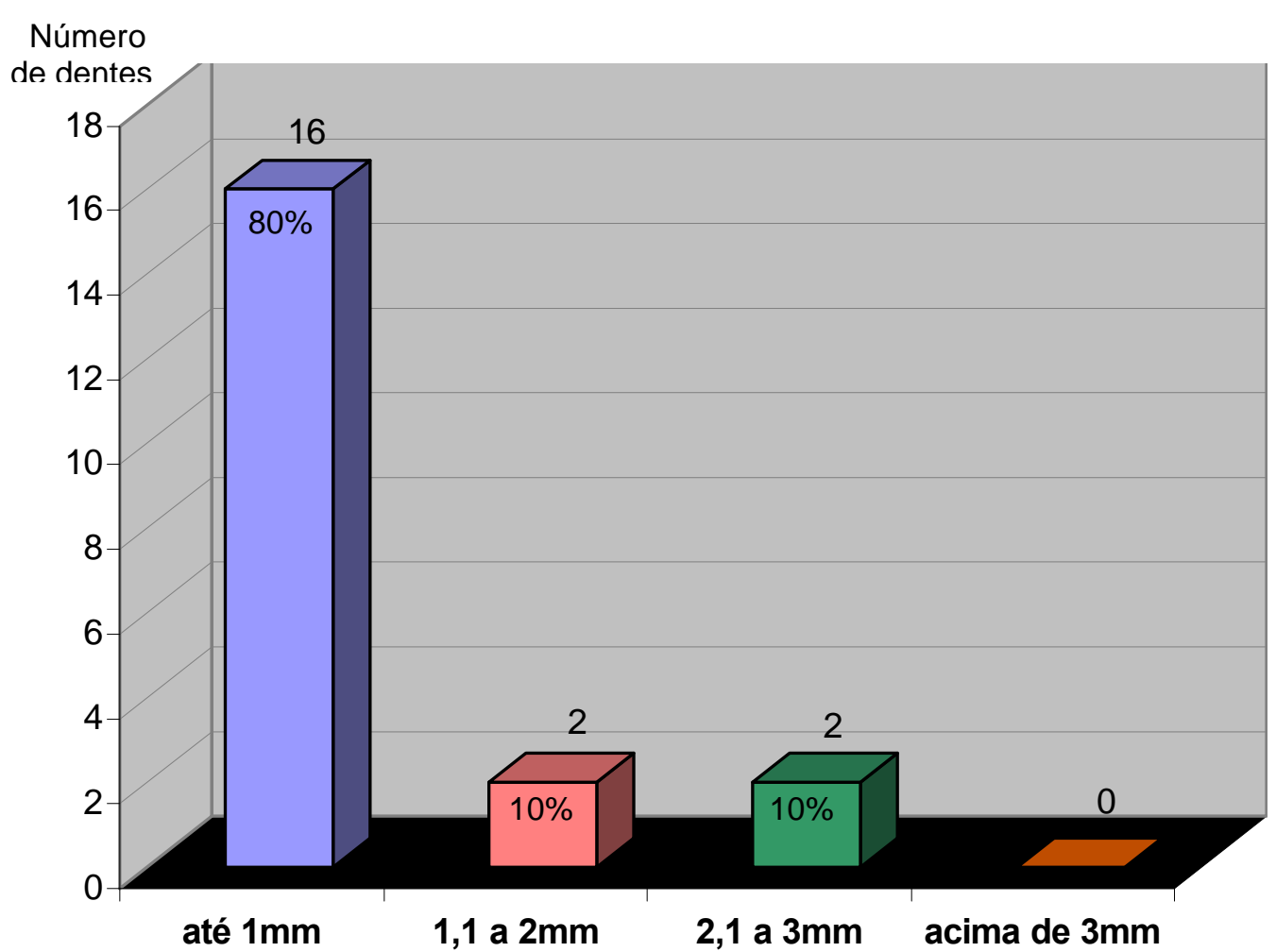

FIGURA 14 - Gráfico da distribuição dos dentes do grupo do System B em função da extensão em que as infiltrações ocorreram
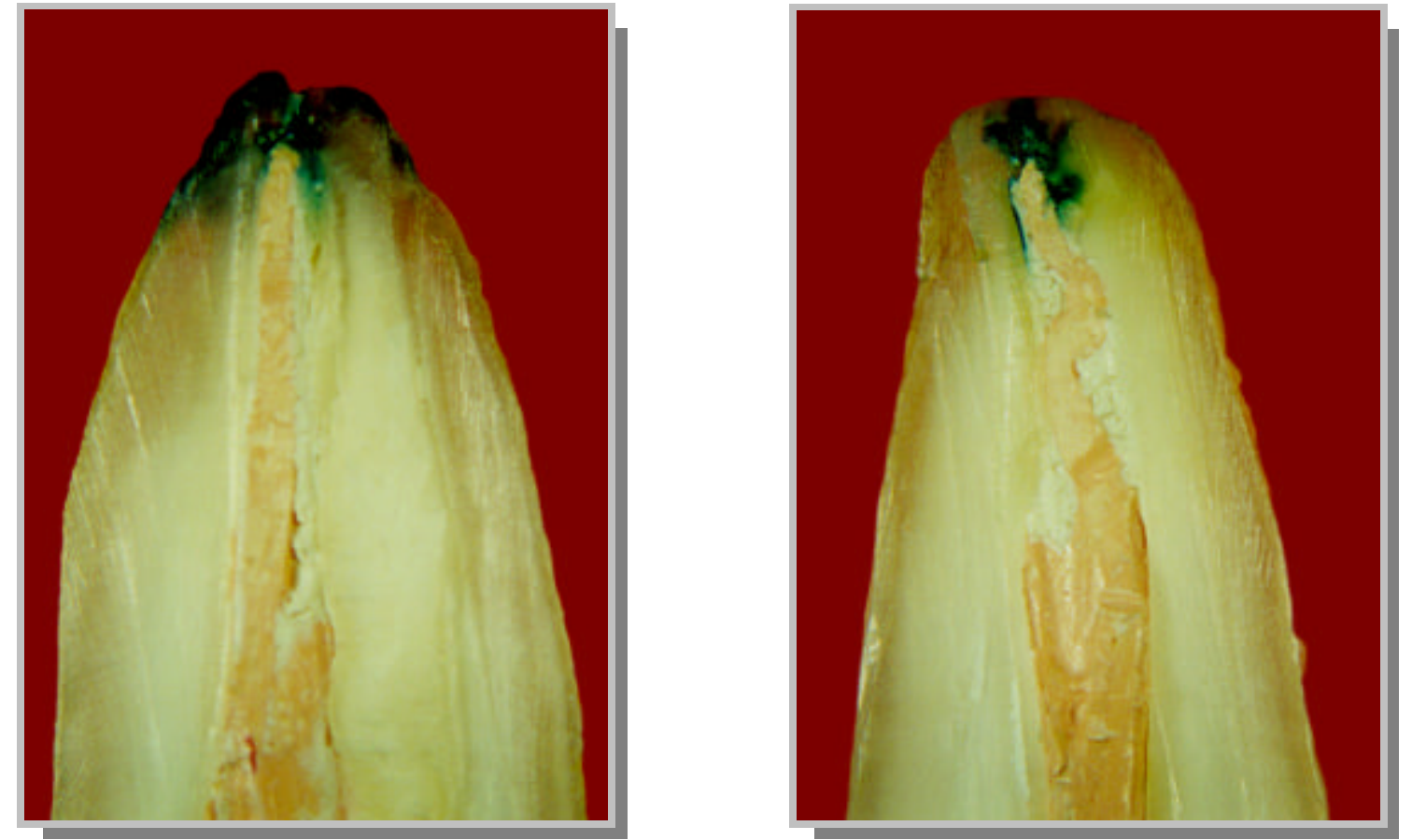

FIGURA 15 - Infiltração apical do corante azul de metileno observada nos espécimes do grupo do System B 


\section{3 - Sistema Ultrafil}

O sistema Ultrafil apresentou infiltração apical média de corante de 2,42 mm, diferenciando-se estatisticamente do sistema Microseal, o qual apresentou infiltração de $0,47 \mathrm{~mm}$. Não houve diferença estatisticamente significante entre o sistema Ultrafil e os demais grupos: condensação lateral $(2,81 \mathrm{~mm})$, System B $(0,82 \mathrm{~mm})$ e JS Quick-Fill (2,34 mm) (Tabela 4).

Entre os espécimes obturados pelo sistema Ultrafil, o menor resultado encontrado foi de $0 \mathrm{~mm}$ (sem infiltração) e o maior de 8,54 mm (Tabela 2). Dos dentes, 40\% apresentaram infiltração apical de corante menor ou igual a $1 \mathrm{~mm}$, $10 \%$ apresentaram infiltração apical entre 1,1 e 2 mm, 25\% apresentaram infiltração apical entre 2,1 e $3 \mathrm{~mm}$ e 25\% apresentaram infiltração apical superior a $3 \mathrm{~mm}$ (Figura 16).

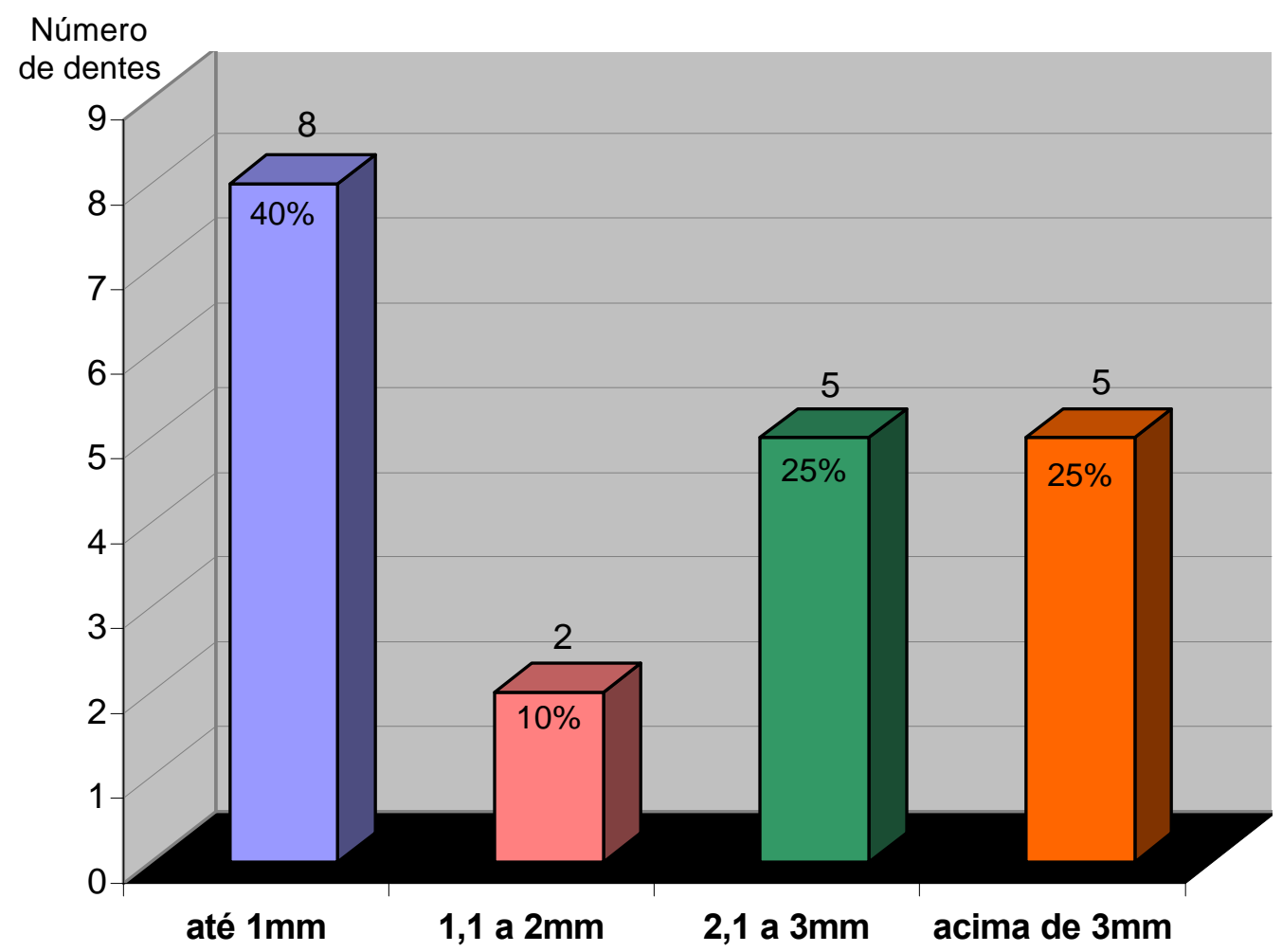

FIGURA 16 - Gráfico da distribuição dos dentes do grupo do sistema Ultrafil em função da extensão em que as infiltrações ocorreram 

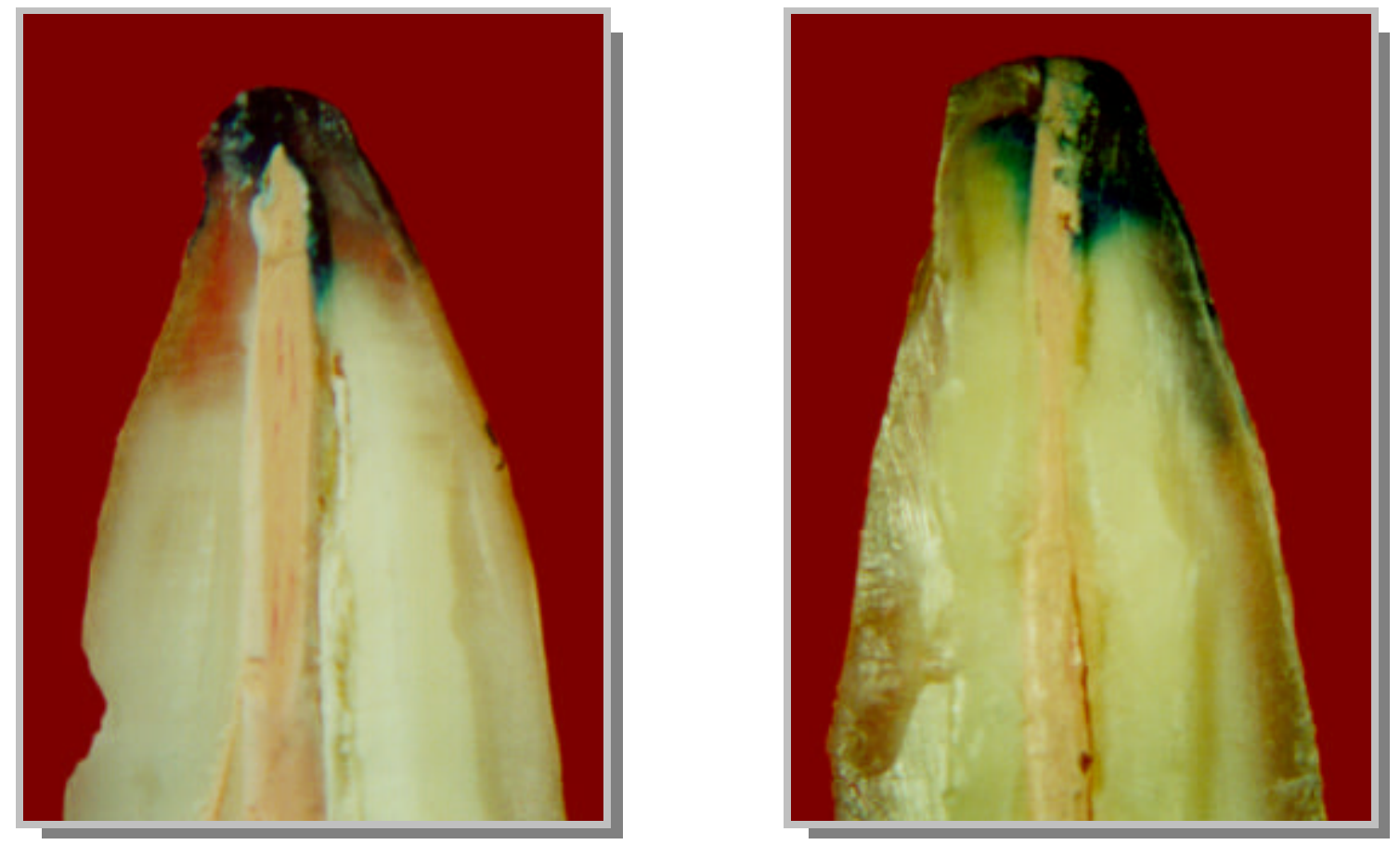

FIGURA 17 - Infiltração apical do corante azul de metileno observada nos espécimes do grupo do sistema Ultrafil

\section{4 - Sistema JS Quick-Fill}

O sistema JS Quick-Fill apresentou infiltração apical média de corante de 2,34 mm, diferindo-se estatisticamente do sistema Microseal, o qual apresentou infiltração de $0,47 \mathrm{~mm}$. Não houve diferença estatisticamente significante entre o sistema JS Quick-Fill e os grupos da condensação lateral $(2,81 \mathrm{~mm})$, System B $(0,82 \mathrm{~mm})$ e Ultrafil $(2,42 \mathrm{~mm})$ (Tabela 4).

Entre os espécimes obturados pelo sistema JS Quick-Fill, o menor resultado encontrado foi de $0 \mathrm{~mm}$ (sem infiltração) e o maior de 7,56 mm (Tabela 2). Dos dentes, 40\% apresentaram infiltração apical de corante menor ou igual a $1 \mathrm{~mm}, 15 \%$ apresentaram infiltração apical entre 1,1 e $2 \mathrm{~mm}, 20 \%$ apresentaram infiltração apical entre 2,1 e 3 mm e 25\% apresentaram infiltração apical superior a $3 \mathrm{~mm}$ (Figura 18). 


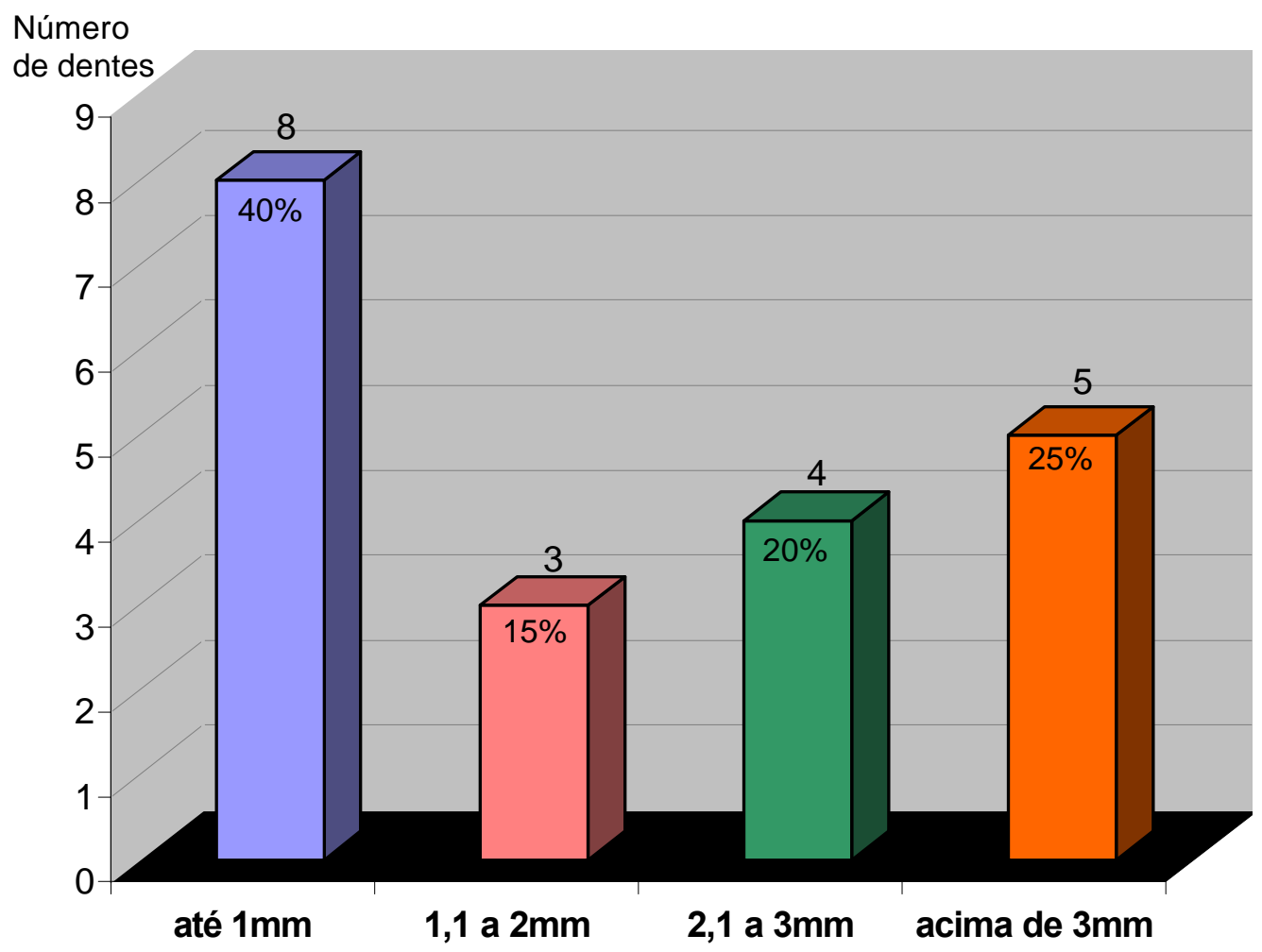

FIGURA 18 - Gráfico da distribuição dos dentes do grupo do sistema JS Quick-Fill em função da extensão em que as infiltrações ocorreram
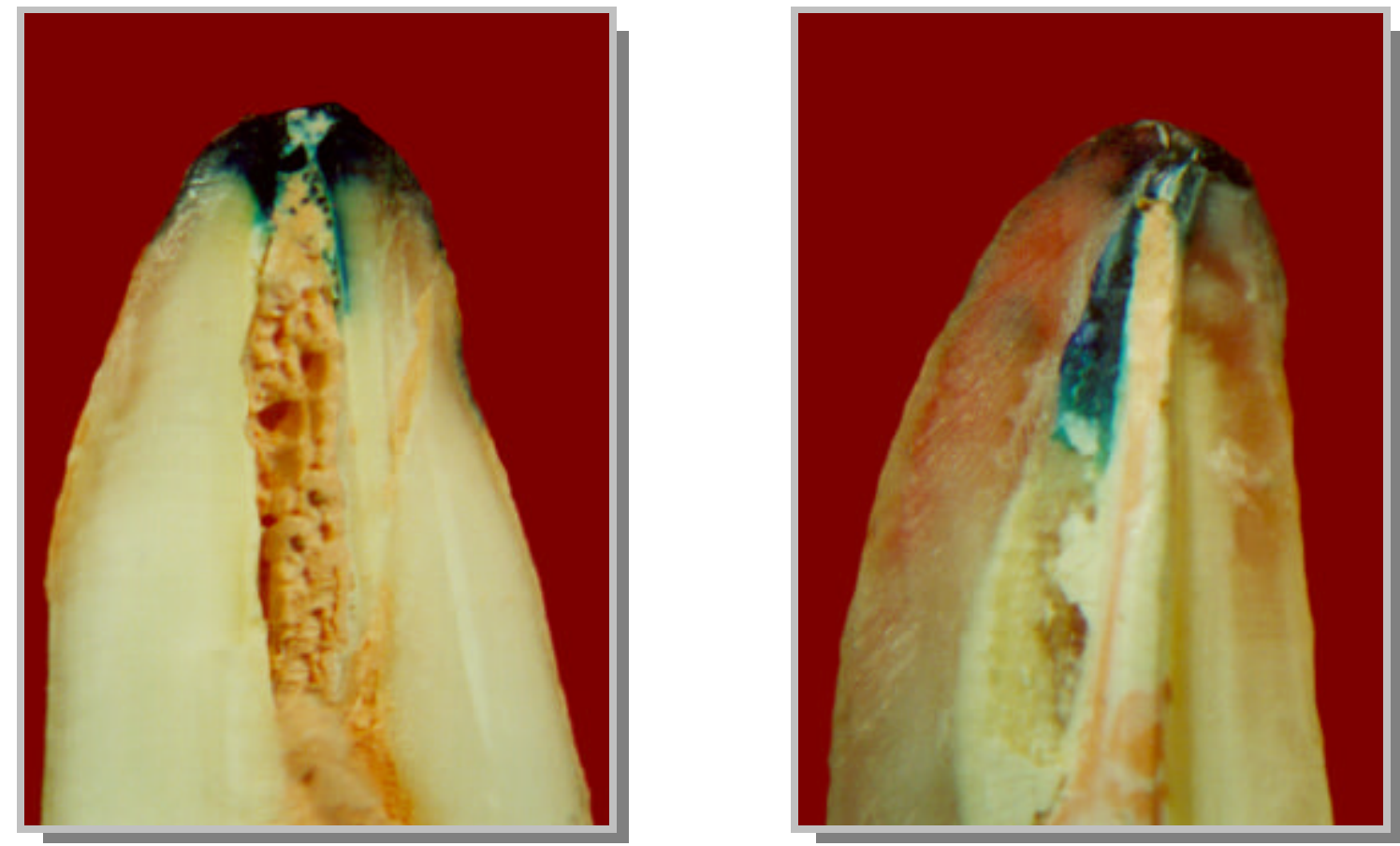

FIGURA 19 - Infiltração apical do corante azul de metileno observada nos espécimes do grupo do sistema JS Quick-Fill 


\section{5 - Sistema Microseal}

O sistema Microseal apresentou menor média de infiltração apical de corante $(0,47 \mathrm{~mm})$ quando comparado aos demais grupos avaliados, diferenciando-se estatisticamente da técnica da condensação lateral $(2,81 \mathrm{~mm})$ e dos sistemas Ultrafil $(2,42 \mathrm{~mm})$ e JS Quick-Fill $(2,34 \mathrm{~mm})$. Não houve diferença estatisticamente significante entre os sistemas Microseal e System B $(0,82 \mathrm{~mm})$ (Tabela 4).

Entre os espécimes obturados com o sistema Microseal, o menor resultado encontrado foi de $0 \mathrm{~mm}$ (sem infiltração) e o maior de 1,70 mm (Tabela 2). Dos dentes, 90\% apresentaram infiltração apical de corante menor ou igual a 1 mm e 10\% apresentaram infiltração apical entre 1,1 e 2 mm (Figura 20).

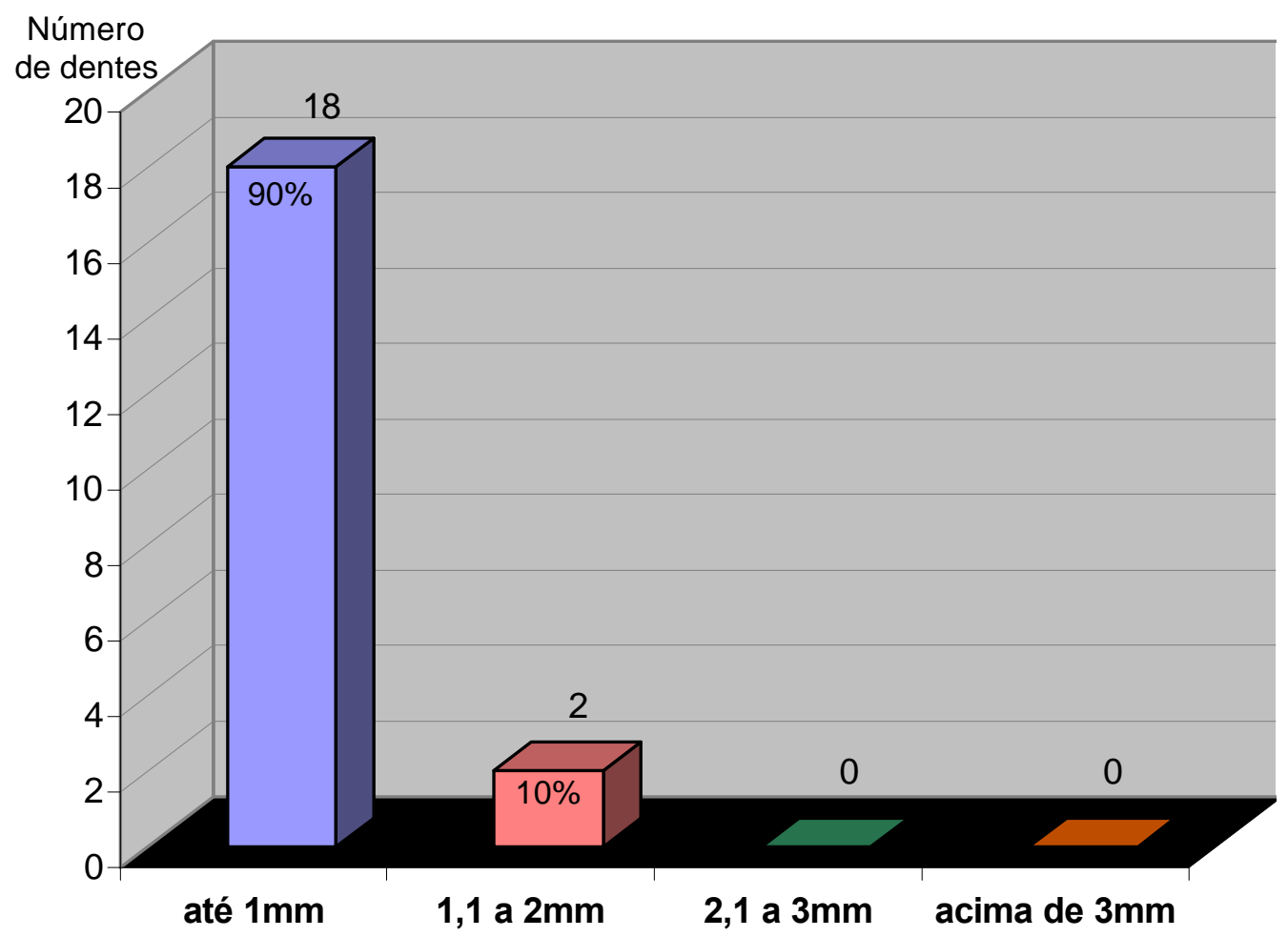

FIGURA 20 - Gráfico da distribuição dos dentes do grupo do sistema Microseal em função da extensão em que as infiltrações ocorreram 

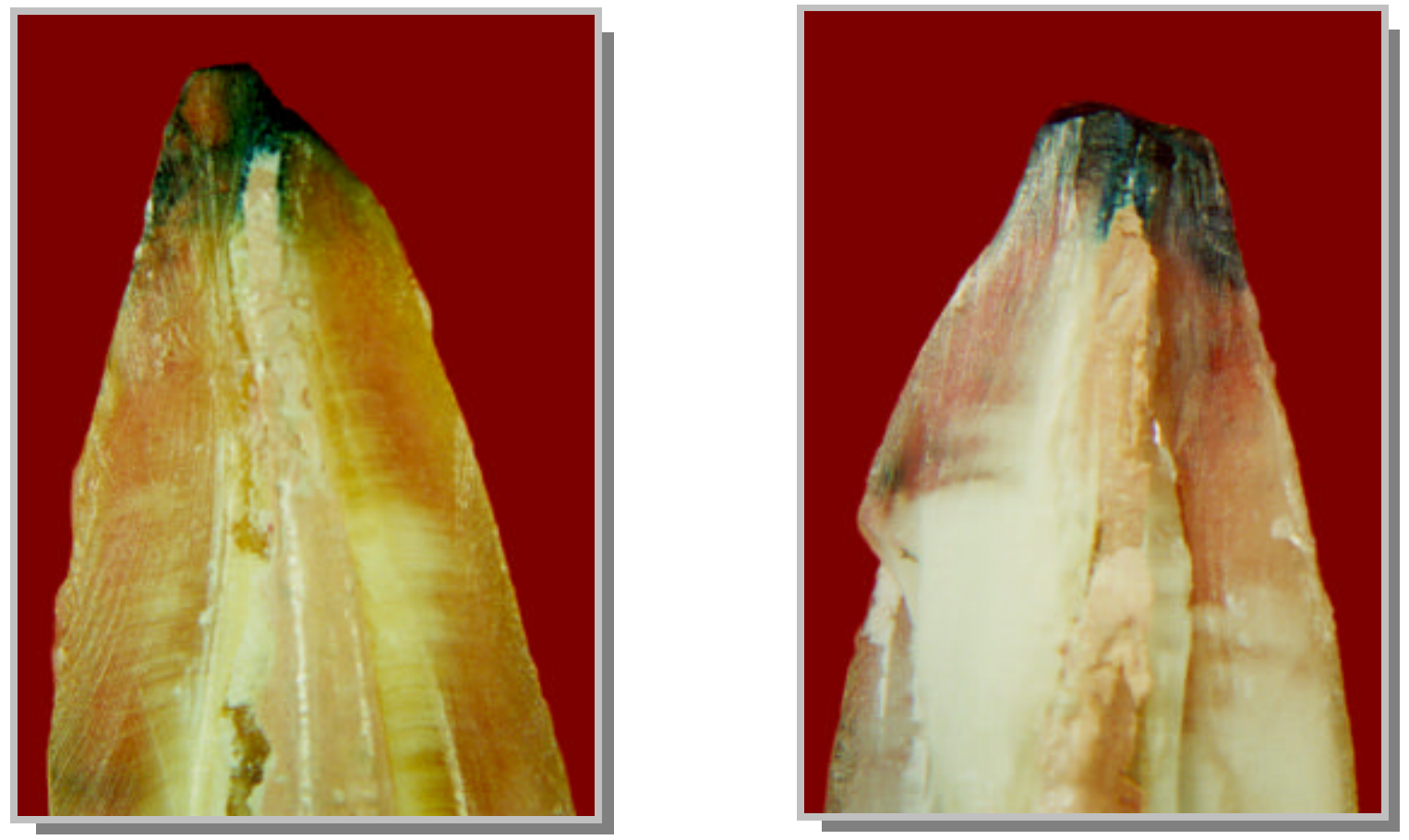

FIGURA 21 - Infiltração apical do corante azul de metileno observada nos espécimes do grupo do sistema Microseal 


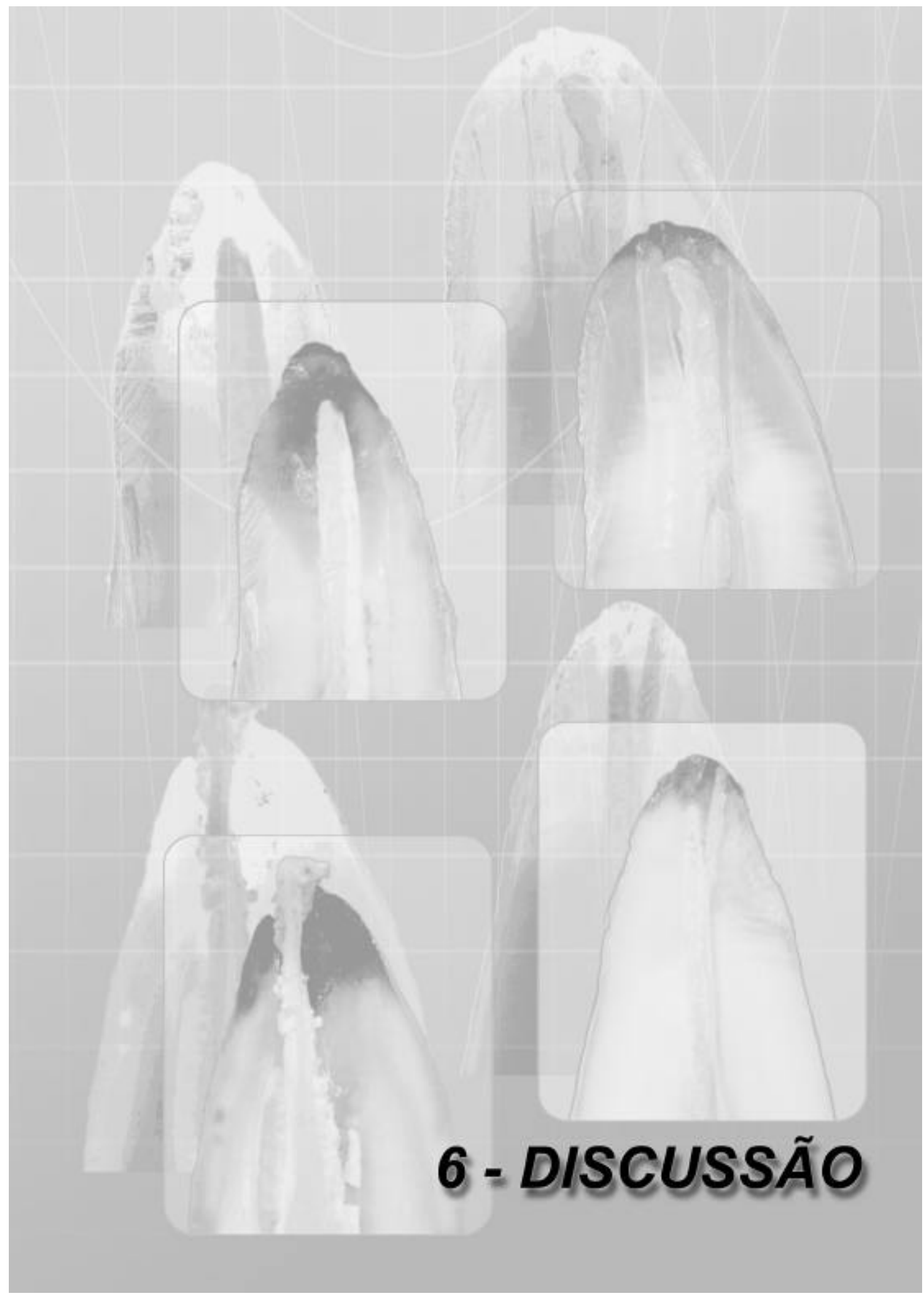




\section{6 - DISCUSSÃO}

\section{1 - Discussão da metodologia}

Para este trabalho, foram selecionados dentes humanos extraídos ${ }^{100,105,128}$ com o objetivo de melhor simular as condições clínicas em que é realizado o tratamento endodôntico ${ }^{1}$.

Diferentes grupos de dentes têm sido utilizados para avaliação da infiltração apical ${ }^{9}, 97,108,144$. Neste estudo, optou-se por utilizar os incisivos inferiores, por apresentarem canais achatados no sentido mésio-distal ${ }^{20,87,}$ ${ }^{116}$ dificultando, muitas vezes, a realização de uma obturação adequada.

Os dentes selecionados apresentavam anatomia e tamanho semelhantes, pois segundo ISHLEY; ELDEEB ${ }^{69}$ e WU; WESSELINK ${ }^{149}$, essas condições entre os grupos são importantes uma vez que são variáveis que podem influenciar nos resultados. Quanto maior for o comprimento da raiz, mais difícil poderá ser o preparo biomecânico ${ }^{105}$ e a área para atuação do corante será maior havendo, portanto, um maior potencial para a infiltração linear ${ }^{69}$.

Com o intuito de amenizar o efeito dessas variáveis, utilizouse um único grupo de dentes com pequena variação de 19 a 22 milímetros no comprimento dental. Além disso, os dentes foram distribuídos considerando-se o tamanho e a morfologia das raízes, visando a uma homogeneidade entre os grupos.

Os dentes foram armazenados em formol a $10 \% 33,58,127$ para que os tecidos fossem fixados e, posteriormente, mantidos em solução fisiológica ${ }^{3,11,103}$ para que permanecessem hidratados durante todo o experimento.

Para a realização do tratamento endodôntico, preservou-se a coroa do dente e realizou-se a abertura coronária na mesma ${ }^{19}, 114,127$ com a finalidade de se conseguir uma maior aproximação das condições clínicas, visto que a remoção da coroa ${ }^{32,33,128}$, por permitir um acesso mais direto ao canal radicular, poderia facilitar a realização da instrumentação e obturação dos canais radiculares. 
A odontometria foi realizada através da visualização da lima no forame apical ${ }^{1,19,114}$, por ser esse método simples, prático e altamente confiável na determinação do comprimento do dente.

A padronização do diâmetro do forame apical é um procedimento importante nos estudos de infiltração apical ${ }^{21}, 101,105,149$. Segundo GREENE; WONG; INGRAM ${ }^{57}$, o diâmetro do instrumento utilizado para padronizar o forame apical pode influenciar na infiltração linear, sendo que limas mais calibrosas possibilitam maiores infiltrações. Neste estudo, a padronização do forame apical foi realizada através da instrumentação do canal, no comprimento total do dente, até a lima $n^{0}$ 25. Com essa manobra, a área de acesso do corante para marcação da infiltração apresentava um diâmetro similar em todos os dentes.

Os canais radiculares foram preparados manualmente por um único operador com o intuito de se eliminarem possíveis variáveis existentes na instrumentação realizada por diferentes operadores. $O$ batente apical foi confeccionado um milímetro aquém do forame apical por ser essa, aproximadamente, a localização do limite CDC (cemento-dentina-canal) ${ }^{56}$ e para possibilitar a criação de um anteparo para o ajuste e travamento do cone de gutapercha. Na seqüência, utilizou-se a técnica escalonada regressiva, sugerida por WEINE ${ }^{147}$, a qual proporcionou um preparo satisfatório dos canais radiculares, possibilitando que as técnicas de obturação pudessem ser realizadas de maneira adequada.

Após a instrumentação, realizou-se a remoção dos resíduos que permaneceram no milímetro apical do canal (desbridamento) com o objetivo de permitir um contato direto entre o corante e a obturação do canal radicular. Esse procedimento também foi verificado nos trabalhos de DAVALOU; GUTMANN; NUNN ${ }^{33}$, GULABIVALA; HOLT; LONG ${ }^{58}$, PALLARÉS; FAUS ${ }^{110}$ e SHAKESPEARE; DONNELLY ${ }^{127}$.

Em seguida, realizou-se a irrigação dos canais radiculares com uma solução de EDTA a 17\%, durante três minutos, para remoção da "smear layer"1, 33, 82 , seguida pela irrigação de solução fisiológica dos mesmos.

A "smear layer" é uma camada constituída por componentes orgânicos (bactérias, restos pulpares) e inorgânicos ${ }^{1,33,82}$, a qual possui de 1 a 2 
micrometros de espessura aderida à parede dentinária do canal radicular e se estende cerca de 40 micrometros no interior dos túbulos dentinários ${ }^{33}$. Se a "smear layer" não for removida após a instrumentação do canal, poderá funcionar como um substrato para a proliferação de bactérias, servir como um caminho para a circulação bacteriana entre a obturação e o canal radicular e dificultar a ação do medicamento intracanal, assim como o embricamento mecânico entre o cimento obturador e as paredes do canal" 33,66, 82. Dessa forma, a eliminação da "smear layer" pode trazer efeitos benéficos para o tratamento endodôntico ${ }^{43}$.

A impermeabilização da superfície externa dos dentes foi

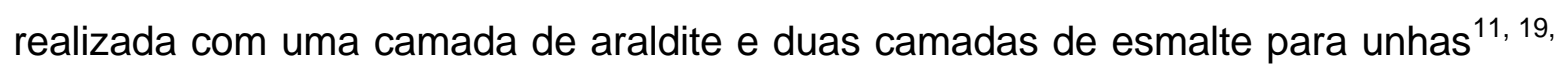
21, 67, 101, 132 com o objetivo de se evitar que o corante penetrasse por outras áreas que não fosse o forame apical, como os túbulos dentinários e canais acessórios ${ }^{19,28,}$ 100, 110, 127. Para a sua execução, inseriu-se um palito de dente na abertura coronária dos dentes, para facilitar o manuseio dos mesmos, e a extremidade de uma lima tipo Kerr número 15 foi introduzida no forame apical para evitar possíveis obstruções do forame pelo material impermeabilizador.

A impermeabilização da superfície externa dos dentes foi realizada antes da obturação dos canais radiculares, como nos trabalhos de BEATTY et al. $^{9}$, BRAMANTE et al. ${ }^{19}$, MORAES ${ }^{101}$ e NUNES ${ }^{105}$, para que os dentes pudessem ser imersos no corante imediatamente após a obturação.

Os dentes foram presos em uma morsa a fim de que permanecessem imóveis durante a obturação. Isso foi realizado para simular a situação clínica do dente preso ao alvéolo dentário, permitindo que o operador trabalhasse com as duas mãos durante a obturação dos canais radiculares.

Os canais radiculares foram obturados com 0 cimento Endofill, que é um cimento à base de óxido de zinco e eugenol. O cimento Endofill é uma versão nacional do tradicional cimento de Grossman, amplamente utilizado na obturação dos canais radiculares ${ }^{87,116}$.

Segundo o fabricante ${ }^{(a)}$, a consistência adequada do cimento Endofill é obtida quando a espátula colocada sobre a mistura é levantada e o

\footnotetext{
(a) ENDOFILL cimento endodôntico. Rio de Janeiro, Dentsply Herpo / Bula do Material /
} 
cimento forma um fio que se rompe ao atingir o comprimento de aproximadamente dois centímetros. Neste estudo, teve-se o cuidado de padronizar a proporção pó/líquido do cimento Endofill, já que essa variável poderia influenciar na infiltração apical. Observou-se que o cimento apresentava a consistência recomendada pelo fabricante quando era misturado na proporção de 0,5 grama de pó para 5 gotas de líquido. Dessa forma, essa proporção foi adotada para a obturação de todos os canais radiculares. Cada porção de cimento era preparada e utilizada na obturação de aproximadamente cinco canais, sendo o restante do cimento descartado, pois o tempo de presa do cimento Endofill é de aproximadamente 20 minutos.

O cimento foi levado ao canal radicular de todos os dentes através da técnica clássica. Essa técnica foi escolhida para padronizar a obturação de todos os grupos, já que a técnica biológica controlada, onde o cimento é levado juntamente com o cone de guta-percha, não poderia ser realizada nos grupos dos sistemas JS Quick-Fill e Ultrafil, visto que essas técnicas de obturação não utilizam cone principal de guta-percha.

A condensação lateral é a técnica de obturação dos canais radiculares mais amplamente utilizada na Endodontia ${ }^{28,32,70}$. Apesar de a maioria dos autores utilizarem espaçadores para a realização da condensação lateral, neste trabalho optou-se pela técnica sugerida por BRAMANTE; BERBERT; PICCINO ${ }^{18}$, em que os espaçadores são substituídos por limas tipo Kerr convencionais.

Antes da obturação dos canais radiculares com as novas técnicas propostas, realizou-se um treinamento das mesmas em diversos dentes extraídos com a finalidade de se adquirir habilidade no manuseio destas e evitar que o resultado da infiltração apical fosse prejudicado pela inexperiência do operador.

A "Técnica da Onda Contínua de Condensação" é uma técnica de obturação que realiza a condensação vertical da guta-percha aquecida com o aparelho System $B^{22,23,82,129 .}$

Os cones principais preconizados para essa técnica são

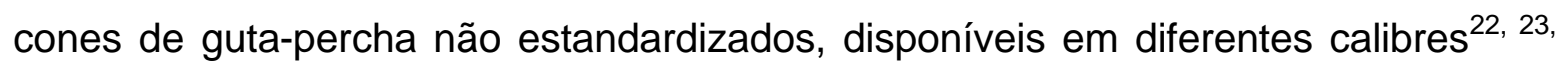
137. Neste estudo, para a obturação dos incisivos inferiores, utilizou-se o cone de guta-percha FM, adaptado no comprimento de trabalho dos canais radiculares ${ }^{36,50}$. 
Segundo BUCHANAN ${ }^{23}$, em canais ovóides pode ser utilizado um segundo cone de guta-percha, lateralmente ao cone de guta-percha principal, para não haver o escape da pressão de condensação durante a obturação. Nos incisivos inferiores, apesar de possuírem canais achatados, não havia espaço para a cimentação de um segundo cone lateralmente ao cone principal FM, visto que este cone apresenta grande conicidade, daí a utilização de apenas um cone principal.

O System B possui condensadores de diferentes conicidades para serem utilizados na técnica da Onda Contínua de Condensação. O condensador mais apropriado ao canal é aquele que apresenta o mesmo calibre do cone de guta-percha previamente selecionado ${ }^{22,23,137}$; dessa forma, o condensador selecionado neste estudo foi o FM.

O condensador deve ser adaptado de 5 a 7 milímetros aquém do comprimento de trabalho ${ }^{13,23,86,120,137}$. Se o preparo do canal estiver inadequado, podem surgir dificuldades em se conseguir inserir a ponta do System B na profundidade adequada. Geralmente, esses condensadores podem ser colocados na mesma profundidade que uma lima no 60 penetra no canal ${ }^{23}$. Neste estudo, durante o escalonamento regressivo do preparo biomecânico, a lima ํㅜ 60 foi inserida quatro milímetros aquém do comprimento de trabalho, o que possibilitou que o condensador fosse adaptado na profundidade adequada.

A temperatura e o tempo utilizados nas diferentes fases da obturação com System B seguiram as recomendações do fabricante. Isso é importante porque quando é utilizada uma temperatura muito alta ou quando a temperatura é mantida por um tempo além do recomendado, a guta-percha poderá ficar superamolecida e o condensador poderá se curvar, não criando uma pressão necessária para a obturação adequada do canal radicular. $O$ aquecimento insuficiente do condensador também é prejudicial pois haverá necessidade de uma força excessiva para empurrá-lo através do cone de guta-percha principal ${ }^{23}$.

Após a obturação do terço apical do canal, na fase "Downpack", realizou-se uma pressão apical com o condensador, durante dez segundos, com a finalidade de se evitar a contração da guta-percha durante o seu esfriamento ${ }^{23,86,94,130,137 .}$. 
Durante a realização da fase "Backfill" com o System B, mesmo seguindo as recomendações do fabricante e realizando um treinamento prévio da técnica, muitas vezes havia a dificuldade de se promover a separação entre o cone de guta-percha principal e o condensador, sendo o cone de gutapercha puxado para fora do canal radicular juntamente com o condensador. Nesses casos, outro cone era novamente assentado e essa etapa repetida. Essa dificuldade também foi encontrada no estudo de MAZOTTI ${ }^{93}$ (2001), que relatou a necessidade de um maior treinamento na obturação dos dentes com o System B quando comparado aos demais sistemas introduzidos recentemente no mercado.

Procurando solucionar a dificuldade acima relatada, alguns autores $^{16,50,82,95,130}$ preconizam a realização da segunda fase da obturação da Técnica da Onda Contínua ("Backfill”) com o aparelho Obtura II, através da técnica da guta-percha injetável. Neste trabalho, essa fase foi realizada com o System B para seguir a técnica original preconizada por BUCHANAN ${ }^{23}$.

O sistema Ultrafil utiliza a técnica da guta-percha termoplastificada injetável em baixa temperatura $\left(70^{\circ} \mathrm{C}\right)$ para a obturação dos canais radiculares ${ }^{31,97,98}$.

A guta-percha do sistema Ultrafil pode ser encontrada em três diferentes viscosidades: "regular set" (branca), "firm set" (azul) e "endo set" (verde) $^{1}, 50,67,143$. Neste estudo, utilizou-se a guta-percha de consistência firme (azul), que apresenta boa fluidez e é recomendada para técnicas de obturação mais simples $^{143}$. Essa guta-percha, após ser removida do aquecedor, apresenta fluidez adequada até 45 a 60 segundos $^{143}$, tempo este que se mostrou suficiente para que fosse realizada a obturação.

Durante a obturação dos canais com o sistema Ultrafil, a guta-percha era injetada pressionando-se e soltando-se o gatilho da seringa e aguardando-se três segundos. Esse tempo de espera era necessário para permitir uma fluidez constante da guta-percha e evitar que se formasse um excesso de pressão na cânula, que poderia danificar a mesma ${ }^{143}$.

A profundidade da inserção da cânula do sistema Ultrafil no canal radicular tem um papel importante no limite da obturação do mesmo ${ }^{84}$. Segundo o fabricante ${ }^{143}$, a cânula deve ser posicionada na distância máxima de 8 a 
10 milímetros aquém do ápice, em uma área onde se adapte firmemente às paredes do canal. Ao mesmo tempo, afirma que, em canais muito amplos, a cânula poderá ser posicionada mais profundamente.

Neste estudo, a cânula do sistema Ultrafil foi inserida seis milímetros aquém do comprimento de trabalho ${ }^{3,9,27,126}$, pois nesse limite a mesma apresentava boa adaptação às paredes do canal, aspecto importante para garantir uma fluidez contínua da guta-percha em direção apical ${ }^{143}$.

GRASSI et al. ${ }^{55}$ verificaram que a guta-percha de consistência firme do sistema Ultrafil apresentava uma temperatura de plastificação de $45,5^{\circ} \mathrm{C}$ e após o seu esfriamento ocorria uma contração de 2,6\% no seu volume. Em virtude dessa contração, e também seguindo as recomendações do fabricante, o sistema Ultrafil foi associado a um cimento obturador, procedimento este realizado por inúmeros pesquisadores ${ }^{1,4,46,103}$.

O sistema JS Quick-Fill utiliza a técnica da obturação termoplastificada mecanicamente para a obturação dos canais radiculares ${ }^{111,122,127 .}$

Para a obturação dos canais radiculares com o sistema JS Quick-Fill selecionou-se um compactador recoberto por guta-percha dois números menores que o do instrumento de memória, como recomendado pelo fabricante ${ }^{73} \mathrm{e}$ realizado também por vários autores ${ }^{28,58,110,127}$, o qual foi inserido até atingir o comprimento de trabalho ${ }^{28,110}$, que se localizava um milímetro aquém do ápice.

A velocidade do compactador recomendada para a obturação dos canais radiculares com o sistema JS Quick-Fill é de 3000 a 6000 $\mathrm{rpm}^{73}$. Neste estudo teve-se o cuidado de utilizar um micromotor elétrico para que a velocidade de 6000 rpm fosse padronizada e constante na obturação de todos os canais desse grupo.

Durante a realização do teste-piloto com o sistema JS QuickFill observou-se que a guta-percha não apresentava uma plastificação adequada quando utilizada na velocidade recomendada pelo fabricante $(3000 \text { a } 6000 \mathrm{rpm})^{73}$. A velocidade do compactador foi aumentada até 12000 rpm e mesmo assim não se obteve uma plastificação adequada. Esse teste foi realizado sem cimento, o que possibilitou uma visualização nítida da plastificação da guta-percha. Tal comportamento do material levantou a hipótese de que o mesmo poderia estar 
apresentando essa característica por algum defeito de fabricação ou prazo de validade vencido e que isso poderia prejudicar os resultados. Porém, um novo lote do material se comportou da mesma maneira que o anterior, sugerindo que a dificuldade da plastificação é uma característica inerente da guta-percha desse sistema.

Neste trabalho, quando o sistema JS Quick-Fill foi utilizado associado ao cimento, procedimento recomendado pelo fabricante, observou-se que a plastificação inadequada da guta-percha foi "mascarada" pelo cimento obturador. Não encontramos na literatura artigos que relatassem esse inconveniente da gutapercha do sistema JS Quick-Fill, talvez pelo fato desse sistema ser sempre utilizado associado a um cimento obturador.

O sistema Microseal é um sistema de obturação misto, que associa um cone principal de guta-percha à guta-percha termoplastificada. Essa guta-percha é inserida no canal radicular com um compactador de níquel-titânio e se funde ao cone principal formando uma massa homogênea no interior do canal ${ }^{81,131}$.

Para a obturação dos canais radiculares com o sistema Microseal, utilizou-se um cone principal de guta-percha de $n^{\circ} 40$, (compatível com o instrumento de memória), de conicidade 0,02 e um compactador de níquel-titânio de conicidade 0,04 , pois segundo o fabricante ${ }^{39}$, quando é utilizado um cone principal de conicidade 0,02, deve-se optar por um compactador de níquel-titânio de conicidade 0,04 e vice-versa.

Durante a obturação, o compactador envolvido pela gutapercha termoplastificada deve ser inserido o mais próximo possível do comprimento de trabalho ${ }^{39,81}$. Com a finalidade de padronizar a profundidade do compactador, o mesmo foi inserido três milímetros aquém do comprimento de trabalho, em todos os dentes desse grupo. Selecionou-se o compactador $n^{0} 45$ por esse atingir a profundidade pré-estabelecida.

O compactador do sistema Microseal deve ser utilizado na

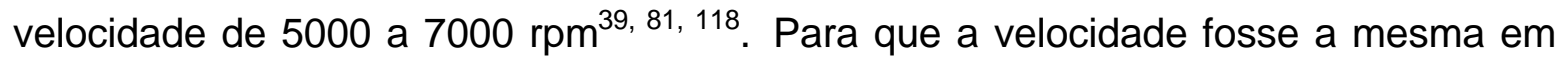
todos os canais obturados, foi utilizado um micromotor elétrico na velocidade constante de $6000 \mathrm{rpm}$. 
Segundo o fabricante ${ }^{39}$ e diversos pesquisadores ${ }^{33,81}$, se a obturação realizada com o sistema Microseal apresentar falhas, o compactador envolvido pela guta-percha termoplastificada poderá ser novamente inserido na obturação do canal radicular a fim de corrigi-las. No teste piloto, verificou-se que quando o compactador era inserido no canal radicular uma única vez, a obturação apresentava algumas falhas, constatadas através de radiografias. Dessa forma, padronizamos duas inserções do compactador para a obturação do canal radicular dos dentes desse grupo.

Ao término da obturação dos canais radiculares, a abertura coronária dos dentes foi selada com cimento temporário Cimpat e impermeabilizada com cera derretida ${ }^{77}$ para evitar a penetração do corante por via coronária.

Na seqüência, os dentes foram imersos no corante, seguindo a metodologia de BRANDÃO ${ }^{21}$, SANTA CECÍLIA ${ }^{121}$ e SOUSA ${ }^{133}$, pois no tratamento endodôntico "in vivo" a obturação entra instantaneamente em contato com os tecidos periapicais. No entanto, alguns autores ${ }^{27,33,63,110}$ preconizam que o dente deve ser armazenado em meio úmido, previamente à sua imersão no corante, para que, antes, ocorra a presa do cimento obturador.

KARAGÖZ-KÜÇÜKAY; KÜÇÜKAY; BAYIRLI ${ }^{77}$, verificaram que não houve diferença nos resultados quando os dentes foram armazenados em meio úmido após a obturação ou imersos no corante imediatamente após a mesma. Porém, KONTAKIOTIS; GEORGOPOULOU; MORFIS ${ }^{80}$, avaliando a penetração de corante em defeitos da obturação ("gaps") secos e úmidos, verificaram que nos dentes onde os defeitos da obturação estavam secos a penetração de corante foi maior quando comparada aos dentes onde os mesmos estavam preenchidos por água. Segundo os autores ${ }^{80}$, quando os dentes são imersos no corante, não sabemos se os defeitos da obturação estão preenchidos ou não por líquido proveniente da armazenagem após a obturação. Caso esses "gaps" estejam preenchidos por líquido, o mesmo poderá influenciar na infiltração de corante, sendo esse mais um motivo pelo qual não armazenamos o dente em meio úmido após a obturação dos canais radiculares.

Nos estudos "in vitro" de infiltração apical, alguns autores têm sugerido o uso de centrífuga ${ }^{38,77}$ ou de vácuo ${ }^{32,51,65,80,106,134}$ com a finalidade 
de remover pequenas "bolsas de ar" aprisionadas nas falhas existentes na obturação dos canais radiculares, as quais poderiam impedir a infiltração de corante nessas áreas ${ }^{80,134,149}$.

Nesta pesquisa, não se utilizou o vácuo baseando-se nos resultados dos trabalhos realizados por ANTONOPOULOS; ATTIN; HELLWIG ${ }^{5}$, MASTERS; HIGA, TORABINEJAD ${ }^{91}$ e RODA; GUTMANN ${ }^{119}$, os quais não verificaram diferença estatisticamente significante na infiltração apical de canais radiculares obturados quando estes foram submetidos ou não ao uso do vácuo.

Segundo MASTERS; HIGA, TORABINEJAD ${ }^{91}$, a natureza porosa da dentina pode permitir que o ar aprisionado na interface entre o canal radicular e a obturação possa se dissipar pelos túbulos dentinários, permitindo que a falha da obturação seja ocupada pelo corante.

Além disso, RODA; GUTMANN ${ }^{119}$ verificaram que, quando os dentes foram colocados sob vácuo, houve a formação de bolhas na camada impermeabilizadora externa da raiz, as quais estouraram posteriormente e permitiram a infiltração de corante por essa via. Os autores ${ }^{91}$ relatam que esse artefato de técnica pode influenciar nos resultados da infiltração apical, podendo ser uma possível explicação para os dentes submetidos ao vácuo apresentarem maior infiltração de corante em alguns estudos. Eles também mencionam que o vácuo pode aumentar o tamanho de falhas da obturação, as quais clinicamente seriam irrelevantes, e criar um espaço artificial para a penetração de corante, levando a interpretações inadequadas dos resultados da infiltração apical.

A infiltração apical pode ser avaliada através da penetração de corantes $^{15,33,127,128}$, radioisótopos ${ }^{27,31,60}$ ou bactérias ${ }^{8,71,151}$ ao longo da obturação dos canais radiculares ${ }^{89}$. Outros métodos de avaliação da infiltração apical baseiam-se na determinação do volume da infiltração apical. Entre eles se encontram: método eletroquímico ${ }^{3,71,115}$, espectrofotometria ${ }^{69,83,149}$, determinação de isótopos radioativos através do aparelho gama ${ }^{27,59}$, transporte de fluido ${ }^{113,150,151}$ e reconstrução tridimensional da raiz ${ }^{89}$.

O método de avaliação da infiltração apical pode influenciar significativamente nos resultados, fato que pôde ser evidenciado claramente no trabalho de LACOMBE et al. ${ }^{83}$, pois quando foi utilizado o método da infiltração linear 
de corante para avaliação da infiltração, a técnica da condensação lateral apresentou melhor capacidade de selamento que o sistema Ultrafil, enquanto que quando se utilizou a espectrofotometria as duas técnicas apresentaram resultados similares.

Neste estudo, a avaliação da infiltração apical foi realizada através da penetração de corante na interface dente/obturação ${ }^{19}$, 63, 128, 140, 149 , por ser esse um método simples ${ }^{115}$, eficiente e de baixo custo.

Dentre os corantes disponíveis, o azul de metileno é um dos mais utilizados nos estudos de infiltração apical ${ }^{3, ~ 9, ~ 21, ~ 57, ~} 118$ 139, 149 . Neste estudo, optou-se por utilizar esse corante devido às suas características como simplicidade e segurança no seu uso ${ }^{121}$, baixo custo ${ }^{1}$, solubilidade em água ${ }^{92}$, fácil difusão ${ }^{92,105}$ e, principalmente, pela efetividade na marcação das falhas existentes na obturação dos canais radiculares ${ }^{92,121}$.

Segundo KONTAKIOTIS; GEORGOPOULOU; MORFIS ${ }^{80}$, WU; WESSELINK ${ }^{149}$ e WU et al. ${ }^{151}$, a infiltração de corante pode ocorrer através dos fenômenos de capilaridade ou difusão. Quando a falha da obturação estiver preenchida por ar, o corante penetrará na mesma através da capilaridade ${ }^{80,151}$, que é um fenômeno que se caracteriza pela penetração de um líquido dentro de pequenos tubos ou pequenos espaços ${ }^{80}$. Quando a falha da obturação estiver preenchida por água, o corante penetrará nesta pela ação de difusão ${ }^{80,151}$, que se caracteriza pelo transporte de uma substância através de um líquido.

O tamanho da molécula do corante utilizado é de grande importância nos estudos de infiltração apical, pois pequenas moléculas como a água podem ter uma infiltração cem vezes maior do que grandes moléculas como a albumina $^{149}$. A bactéria possui um tamanho molecular grande, porém, nas falhas da obturação, podem penetrar subprodutos do seu metabolismo ou componentes da sua parede celular, como os lipopolissacarídeos, que podem iniciar ou manter um processo inflamatório ${ }^{8}, 60$. Dessa forma, uma obturação impermeável a essas pequenas moléculas é desejável ${ }^{21}$.

Devido à possibilidade da penetração dos subprodutos das bactérias e dos componentes da sua parede celular nas falhas da obturação, os corantes com pequeno peso molecular são indicados para o estudo da infiltração 
apical $^{149}$. KERSTEN; MOORER ${ }^{79}$ demonstraram que o azul de metileno apresentou infiltração semelhante à do ácido butírico, um produto metabólico tóxico dos microorganismos, simulando, dessa forma, a infiltração das toxinas bacterianas.

MATLOFF et al. ${ }^{92}$ verificaram que 0 azul de metileno penetrou mais facilmente nas falhas da obturação do canal radicular que os isótopos radioativos, sendo aquele recomendado para os estudos de infiltração apical.

O azul de metileno tem sido utilizado em diferentes concentrações, que variam de $0,25 \%$ a $2 \%{ }^{15,19,21,57,63,118}$. Neste trabalho, utilizouse a solução aquosa de azul de metileno a $2 \%{ }^{101,105,133}$, com pH neutro $(\mathrm{pH}=7,0)$ pois, segundo alguns autores ${ }^{46,57,149}$, quando o pH da solução corante é ácido pode desmineralizar a dentina e alterar a quantidade da infiltração apical, sendo o ajuste do $\mathrm{pH}$ da solução para neutro um procedimento importante nos trabalhos de infiltração ${ }^{149}$.

Os dentes foram mantidos no corante durante setenta e duas horas, como nos trabalhos de BERNARDINELI ${ }^{11}$, MORAES ${ }^{101}$, NUNES ${ }^{105}$, e SILVA NETO et al. ${ }^{128}$, tempo que se mostrou suficiente para que ocorresse a infiltração apical, embora alguns autores ${ }^{101}, 133$ relatem um aumento na infiltração de corante em dentes armazenados por períodos mais longos.

Os dentes imersos no corante foram armazenados em estufa, a $37^{\circ} \mathrm{C}$, para simular a temperatura em que os dentes são mantidos "in vivo".

Para que se visualizasse a infiltração de corante, os dentes foram seccionados no sentido longitudinal. Esse método é amplamente utilizado para expor a interface entre a obturação e a parede do canal radicular ${ }^{11,21,101,128} \mathrm{e}$ foi escolhido devido à facilidade, rapidez e domínio da técnica e por preservar a integridade da obturação do canal radicular".

A avaliação da infiltração linear de corante foi realizada com o auxílio de um estereomicroscópio, como nos trabalhos de DAVALOU; GUTMANN; NUNN $^{33}$ e GULABIVALA; HOLT; LONG ${ }^{58}$, o que possibilitou uma visualização adequada da infiltração na interface entre a obturação e as paredes do canal. 


\section{2 - Discussão dos resultados}

A obturação satisfatória do sistema de canais radiculares, isto é, de forma mais hermética possível e dentro de um limite adequado, é importante para o sucesso em Endodontia ${ }^{87}$.

INGLE et al. ${ }^{68}$ avaliaram radiograficamente dentes que tinham sido submetidos ao tratamento endodôntico, nos períodos de dois e cinco anos após o término do tratamento, e verificaram que aproximadamente $60 \%$ dos insucessos são em decorrência de uma obturação insatisfatória do canal radicular.

O selamento adequado tem sido considerado como um prérequisito importante para sucesso da obturação dos canais radiculares e, conseqüentemente, do tratamento endodôntico ${ }^{51,139} 149$, pois evita a comunicação entre o canal radicular e os tecidos periapicais ${ }^{5,65}$.

O selamento apical inadequado da obturação poderá favorecer a ocorrência da infiltração apical, que se caracteriza pela passagem de bactérias e seus produtos e dos fluidos teciduais na interface entre o material obturador e as paredes do canal radicular ${ }^{82,141}$. A passagem de microorganismos e toxinas para os tecidos periapicais poderá induzir à inflamação desses tecidos e, conseqüentemente, reduzir o sucesso da terapia endodôntica ${ }^{82}$.

A presença de foraminas e ramificações do canal radicular também favorecem a ocorrência da infiltração ${ }^{82}$, sendo assim, o selamento dessas estruturas é desejável.

O selamento apical está intimamente associado à técnica de obturação e aos materiais nela utilizados. Para que se consiga uma obturação hermética, é necessário que se utilizem técnicas adequadas associadas a bons materiais seladores ${ }^{87}$.

Com base nos resultados do estudo de INGLE et al. ${ }^{68}$, inúmeros pesquisadores passaram a avaliar a capacidade de selamento dos materiais e técnicas de obturação ${ }^{119}$, levando a um aumento considerável no número de publicações sobre infiltração apical nas últimas décadas ${ }^{149}$.

A maioria dos estudos sobre selamento apical tem sido realizada "in vitro". Segundo KARAGÖZ-KÜÇÜKAY; KÜÇÜKAY; BAYIRLI", apesar 
de os estudos experimentais não reproduzirem exatamente as mesmas condições clínicas e o relacionamento entre as medidas da infiltração "in vivo" e "in vitro" não ser ainda bem estabelecido, o caminho mais razoável para testar a eficácia dos materiais e técnicas de obturação é a realização dos estudos "in vitro", sendo que a extrapolação dos resultados para as condições clínicas deverá ser realizada com bastante cuidado.

Apesar de ter sido demonstrado que a infiltração apical pode promover insucessos no tratamento endodôntico, ainda não se estabeleceu qual a quantidade de infiltração necessária para causar tais prejuízos ${ }^{58,82}$. Embora muitas vezes péssimas obturações resultem em sucesso clínico, tal conduta não deve servir como estímulo para a realização de obturações inadequadas. OLIVER; ABBOTT ${ }^{107}$ verificaram que a obturação pode permitir a infiltração de pequenas moléculas e o tratamento endodôntico ser clínica e radiograficamente caracterizado como sucesso.

$\mathrm{Na}$ literatura existe uma grande variabilidade nos resultados encontrados nos estudos sobre infiltração apical, já que vários fatores como remoção da "smear layer", técnica de obturação, cimento obturador, tipo de corante, método de avaliação da infiltração apical, dentre inúmeros outros, podem influenciar nos resultados obtidos.

A condensação lateral é a técnica de obturação dos canais radiculares mais amplamente utilizada na Endodontia e, sendo assim, é freqüentemente empregada para a avaliação comparativa da capacidade de selamento das novas técnicas de obturação ${ }^{28,32,70,149}$.

Os trabalhos apresentam resultados altamente variáveis na média da infiltração apical de dentes obturados pela técnica da condensação lateral. WU; WESSELINK ${ }^{149}$, fazendo um levantamento de canais radiculares obturados por essa técnica, em diferentes estudos, verificaram que a infiltração apical média pode variar de 0,12 a 9,25 milímetros.

A técnica da condensação lateral, em nosso trabalho, apresentou a maior média de infiltração apical $(2,81 \mathrm{~mm})$, sendo essa média semelhante à dos trabalhos de BRAMANTE et al. ${ }^{19}$, HOLLAND; MURATA; DEZAN JUNIOR ${ }^{63}$ e HOLLAND et al. ${ }^{67}$. No entanto, BONETTI FILHO et al. ${ }^{15}$, PALLARÉS; FAUS $^{110}$ e SHAKESPEARE; DONNELLY ${ }^{127}$, trabalhando com a técnica da 
condensação lateral, encontraram menores médias de infiltração, enquanto BEATTY et al. ${ }^{9}$ e GREENE; WONG; INGRAM ${ }^{57}$ verificaram valores maiores. Esses dados confirmam a diversificação dos resultados que existem em relação à técnica.

ALLISON; MICHELICH; WALTON ${ }^{2}$ verificaram que a profundidade da inserção do espaçador apresenta grande importância na infiltração apical de canais radiculares obturados pela técnica da condensação lateral, sendo que quando os espaçadores são inseridos em maiores profundidades promovem um melhor selamento apical. Dessa forma, além das diferentes variáveis que podem influenciar na infiltração, esse fator pode ter sido um dos responsáveis pelas diferenças nos resultados encontrados.

No grupo da condensação lateral, como se pode observar pela Tabela 2, houve também uma grande variação no índice de infiltração apical entre os diferentes espécimes (de 0,49 $\mathrm{mm}$ a $8,78 \mathrm{~mm}$ ), sendo que $40 \%$ dos dentes apresentaram infiltração apical superior a três milímetros (Figura 12).

A técnica da condensação lateral não produz uma massa homogênea da obturação, sendo esta composta por um cone de guta-percha principal e por vários cones de guta-percha secundários, interligados pelo cimento obturador $^{122,}{ }^{130}$. A obturação realizada por essa técnica apresenta menor reprodução das irregularidades e, conseqüentemente, pior adaptação às paredes do canal, quando comparada às obturações realizadas pelas técnicas que utilizam gutapercha termoplastificada ${ }^{45}$. Talvez isso possa justificar, neste estudo, o fato de os canais radiculares obturados por essa técnica terem apresentado a maior média de infiltração apical.

O grupo do sistema Microseal apresentou a menor média de infiltração apical de corante $(0,47 \mathrm{~mm})$ e, conseqüentemente, a melhor capacidade de selamento apical das técnicas estudadas.

A capacidade de selamento do sistema Microseal foi altamente satisfatória, visto que $90 \%$ dos dentes apresentaram infiltração apical menor que um milímetro (Figura 20). Esse resultado está de acordo com os estudos de DAVALOU; GUTMANN; NUNN ${ }^{33}$, onde todos os espécimes desse grupo também apresentaram infiltração apical inferior a um milímetro. 
O sistema Microseal $(0,47 \mathrm{~mm})$ apresentou menor infiltração apical de corante que o grupo da condensação lateral $(2,81 \mathrm{~mm})$, com diferença estatisticamente significante. Esse resultado está de acordo com o trabalho de BONETTI FILHO et al. ${ }^{15}$ que, além de encontrarem uma média de infiltração para o sistema Microseal semelhante à encontrada em nosso estudo $(0,69 \mathrm{~mm})$, também verificaram que o sistema Microseal apresentava melhor selamento que a técnica da condensação lateral.

Quando comparados aos grupos Ultrafil $(2,42 \mathrm{~mm})$ e JS Quick-Fill (2,34 mm), os dentes obturados pelo sistema Microseal (0,47 mm) também apresentaram melhor capacidade de selamento apical, com diferença estatisticamente significante.

DAVALOU; GUTMANN; NUNN ${ }^{33}$ não verificaram diferença estatisticamente significante na infiltração apical dos dentes obturados pelos sistemas Microseal e System B, corroborando os resultados do nosso estudo.

A melhor capacidade de selamento apresentada pelo sistema Microseal pode ter ocorrido devido às propriedades da guta-percha desse sistema, que emprega guta-percha de baixa fusão. Segundo o fabricante, a gutapercha do cone principal é processada para apresentar fluidez quando submetida à pressão dos compactadores, enquanto a guta-percha termoplastificada, que é inserida no compactador, apresenta viscosidade adequada para apresentar boa aderência às paredes do canal.

Segundo BONETTI FILHO et al. ${ }^{15}$, a guta-percha de baixafusão do sistema Microseal associada ao compactador possibilita uma obturação composta por grande quantidade de guta-percha e por uma fina camada de cimento entre a guta-percha e a parede do canal, permitindo um melhor selamento. Além disso, segundo os autores, quando o compactador é inserido no canal, o cone de guta-percha é forçado ao encontro do batente apical, promovendo uma moldagem do preparo apical e, conseqüentemente, melhor selamento apical.

MAZOTTI $^{93}$ verificou que as obturações realizadas com o sistema Microseal apresentaram-se mais homogêneas e com um menor número de falhas quando comparadas às obturações realizadas pela técnica da condensação lateral. DAVALOU; GUTMANN; $\mathrm{NUNN}^{33}$ também verificaram que as obturações 
realizadas com o sistema Microseal foram efetivas na obturação das irregularidades do canal radicular. Em nosso trabalho, acreditamos que esses fatores também possam ter contribuído para o melhor selamento apical desse grupo.

O grupo do System B apresentou a segunda menor média de infiltração apical de corante $(0,82 \mathrm{~mm})$, sendo essa média semelhante à encontrada nos trabalhos de DAVALOU; GUTMANN; NUNN ${ }^{33}$, KYTRIDOU; GUTMANN; NUNN ${ }^{82}$ e SILVA NETO et al. ${ }^{128}$.

A capacidade de selamento do System B foi bastante satisfatória, visto que $80 \%$ dos dentes apresentaram infiltração apical de corante menor ou igual a um milímetro (Figura 14). Esse resultado está de acordo com os estudos de DAVALOU; GUTMANN; $\mathrm{NUNN}^{33}$, onde os espécimes desse grupo também apresentaram pequena infiltração apical, ou seja, apenas um dente apresentou infiltração apical maior que um milímetro.

O grupo do System B $(0,82 \mathrm{~mm})$ apresentou menor infiltração apical que o da técnica da condensação lateral $(2,81 \mathrm{~mm})$, com diferença estatisticamente significante. POMMEL; CAMPS ${ }^{114}$, comparando essas duas técnicas de obturação, também verificaram resultados semelhantes.

Apesar de o System B apresentar uma média de infiltração apical bem menor $(0,82 \mathrm{~mm})$ que a dos sistemas JS Quick-Fill $(2,34 \mathrm{~mm})$ e Ultrafil $(2,42 \mathrm{~mm})$, não houve entre eles diferença estatisticamente significante na infiltração apical. Isso pode ter ocorrido em função do grande desvio-padrão desses grupos, o que caracteriza a grande variabilidade nos resultados da infiltração apical apresentada pelos diferentes espécimes dentro de cada grupo. Na literatura, não encontramos trabalhos que comparassem a infiltração apical apresentada por esses sistemas, provavelmente pela introdução recente do System B e do JS Quick-Fill no mercado.

A boa capacidade de selamento apresentada pelo System B também pode ter ocorrido devido aos mesmos fatores do sistema Microseal, ou seja, pelas propriedades da guta-percha desse sistema e pela ação do condensador aquecido que, ao empurrar a guta-percha ao encontro do batente apical, promoveria uma moldagem dessa região e, conseqüentemente, um melhor selamento. 
O System B propicia uma obturação densa e tridimensional, com excelente reprodução das irregularidades ${ }^{16,33,130}$ e ótima adaptação da gutapercha às paredes do canal ${ }^{82}$. Segundo KYTRIDOU; GUTMANN; NUNN ${ }^{82}$, essas características podem contribuir para um melhor selamento apical apresentado por esse sistema. DULAC et al. ${ }^{36}$ e GOLDBERG; ARTAZA; SILVIO ${ }^{49}$ também relataram que o System $B$ se mostrou bastante efetivo na obturação de canais laterais com guta-percha.

O sistema JS Quick-Fill apresentou infiltração apical média de corante de 2,34 mm. PALLARÉS; FAUS ${ }^{110}$ encontraram uma média de infiltração apical maior para esse sistema, enquanto SHAKESPEARE; DONNELLY ${ }^{127}$ verificaram uma média menor.

No grupo do sistema JS Quick-Fill, houve uma grande variação na infiltração apical entre os diferentes espécimes $(0,00 \mathrm{~mm}$ a 7,56 mm), como pode ser observado na Tabela 2. SHAKESPEARE; DONNELLY ${ }^{127}$, trabalhando com esse sistema, também verificaram uma grande variação na infiltração apical apresentada pelos diferentes espécimes mostrando, com isso, uma certa instabilidade do material.

A infiltração apical apresentada pelo sistema JS Quick-Fill foi maior que a do sistema Microseal, com diferença estatisticamente significante. Embora essas duas técnicas de obturação utilizem um compactador revestido por guta-percha termoplastificada, provavelmente o melhor desempenho do sistema Microseal se deva ao fato do mesmo associar um cone principal à guta-percha termoplastificada, o que poderia promover um melhor selamento.

Outro aspecto que deve ser analisado no sistema JS QuickFill é se a quantidade de guta-percha que permanece no canal após a remoção do compactador de titânio é suficiente para promover uma obturação adequada do sistema de canais radiculares. Como esse sistema de obturação é relativamente novo, sugerimos a realização de novas pesquisas com o intuito de uma melhor avaliação das suas características.

Não houve diferença estatisticamente significante entre a infiltração apical apresentada pelos dentes do sistema JS Quick-Fill $(2,34 \mathrm{~mm})$ e dos grupos da condensação lateral $(2,81 \mathrm{~mm})$, System B $(0,82 \mathrm{~mm})$ e Ultrafil $(2,42 \mathrm{~mm})$. 
CANALDA-SAHLI; BERÁSTEGUI-JIMENO; BRAUAGUADÉ ${ }^{28}$ e PALLARÉS; FAUS ${ }^{110}$ também verificaram que não houve diferença estatisticamente significante na infiltração apical de canais radiculares obturados pela técnica da condensação lateral e pelo sistema JS Quick-Fill. No entanto, GULABIVALA; HOLT; LONG $^{58}$ e SHAKESPEARE; DONNELLY ${ }^{127}$ mostraram que a técnica da condensação lateral apresentou melhor selamento apical que o sistema JS Quick-Fill.

O sistema Ultrafil apresentou infiltração apical média de corante de 2,42 mm, sendo a mesma semelhante à encontrada nos trabalhos de AMDITIS et al. ${ }^{4}$ e LACOMBE et al. ${ }^{83}$. No entanto, BRAMANTE et al. ${ }^{19}$ e GREENE; WONG; INGRAM ${ }^{57}$ encontraram uma média de infiltração apical maior para esse sistema, enquanto ARTAZA ${ }^{6}$, BEATTY et al. ${ }^{9}$ e OLSON; HARTWELL; WELLER ${ }^{108}$ verificaram uma média menor.

No grupo do sistema Ultrafil também houve uma grande variação na infiltração apical dentre os diferentes espécimes do mesmo grupo $(0,00$ $\mathrm{mm}$ a $8,54 \mathrm{~mm}$ ) como pode ser observado na Tabela 2.

Não houve diferença estatisticamente significante entre a infiltração apical apresentada pelos dentes do sistema Ultrafil e dos grupos da condensação lateral $(2,81 \mathrm{~mm})$, System B $(0,82 \mathrm{~mm})$ e JS Quick-Fill $(2,34 \mathrm{~mm})$.

$\mathrm{Na}$ literatura, existem resultados conflitantes quando se compara a infiltração de canais radiculares obturados pela técnica da condensação lateral e pelo sistema Ultrafil. ARTAZA ${ }^{6}$, CALLIS; PATERSON ${ }^{27}$, DALAT; SPANGBERG ${ }^{32}$ e GREENE; WONG; INGRAM ${ }^{57}$ verificaram que não houve diferença na infiltração apical de canais radiculares obturados por essas duas técnicas, corroborando os resultados do nosso estudo. No entanto, BRAMANTE et al. ${ }^{19}$ mostraram que a técnica da condensação lateral apresentou menor infiltração apical, enquanto outros autores ${ }^{1,9,46}$ relataram que o sistema Ultrafil exibiu menor infiltração apical.

GENÇOGLU, SAMANI; GÜNDAY ${ }^{45}$, MICHANOWICZ; CZONSTKOWSKY; PIESCO ${ }^{98}$ e PERRONE et al. ${ }^{112}$ demonstraram que as obturações realizadas com o sistema Ultrafil apresentam-se homogêneas e com ótima adaptação às irregularidades do canal, inclusive com obturação dos canais 
laterais e acessórios com guta-percha. No entanto, mesmo apresentando melhores características da obturação, o sistema Ultrafil apresentou selamento apical semelhante ao da técnica da condensação lateral.

Alguns fatores como a remoção da "smear layer" após a instrumentação dos canais radiculares e o emprego de cimento obturador associado à guta-percha termoplastificada podem influenciar no selamento apical dos canais radiculares.

Segundo a literatura, existem controvérsias sobre o efeito da remoção da "smear layer" no selamento apical dos canais radiculares. GENÇOGLU; SAMANI; GÜNDAY ${ }^{46}$, HOLLAND et al. ${ }^{66}$, KARAGOZ-KÜÇÜKAY; BAYIRLI' ${ }^{76}$ e MORAES ${ }^{100}$ verificaram que a remoção da "smear layer" promove um melhor selamento apical dos canais radiculares. Porém, TIMPAWAT; VONGSAVAN; MESSER ${ }^{141}$ mostraram que a remoção da "smear layer" aumenta a infiltração apical, enquanto FRÓES; HORTA; SILVEIRA ${ }^{43}$ não verificaram diferença estatisticamente significante no selamento dos canais radiculares com a presença ou não da "smear layer".

Segundo GENÇOGLU; SAMANI; GÜNDAY45, quando são utilizadas técnicas de obturação que empregam guta-percha termoplastificada é importante a remoção da "smear layer" para que haja a exposição dos túbulos dentinários e, conseqüentemente, uma adaptação mais íntima da guta-percha às paredes do canal. PALLARÉS; FAUS; GLICKMAN ${ }^{111}$ verificaram que quando a "smear layer" foi removida houve a penetração de cimento e guta-percha nos túbulos dentinários de canais radiculares obturados por guta-percha termoplastificada, fato que não foi observado quando a mesma foi preservada.

Outro fator importante a ser considerado, principalmente em função das novas técnicas de obturação, é a alteração volumétrica que a gutapercha sofre em função do seu aquecimento e esfriamento. Quando aquecida, a guta-percha se expande e, após o seu esfriamento, se contrai. No entanto, segundo LEE et al. ${ }^{85}$, WEINE ${ }^{147}$ e WU; GEE; WESSELINK ${ }^{150}$, a contração da guta-percha geralmente é maior que a expansão ocorrida anteriormente, podendo originar fendas entre o material e a parede do canal $^{135}$, que poderiam aumentar a infiltração apical. 
Alguns fatores como emprego da guta-percha em temperaturas mais baixas $^{27}$, realização da condensação vertical ${ }^{122,137}$ e uso do cimento podem minimizar os efeitos da contração que a guta-percha sofre após seu esfriamento ${ }^{55}$.

Quanto maior for a temperatura de aquecimento da gutapercha, maior será a contração após o esfriamento ${ }^{135}$. Sendo assim, o sistema Ultrafil apresenta uma vantagem em relação à técnica da guta-percha termoplastificada injetável original de YEE et al. ${ }^{152}$, pois a temperatura necessária para que a guta-percha se plastifique é de $70^{\circ} \mathrm{C}$, bem inferior quando comparada à técnica original, que era de $160^{\circ} \mathrm{C}$. Essa temperatura mais baixa pode resultar em menor contração da guta-percha após seu esfriamento e, conseqüentemente, promover um melhor selamento apical ${ }^{27}$.

Outro fator de grande importância para o sucesso do tratamento endodôntico é o limite apical da obturação ${ }^{10}$. Segundo GULABIVALA; HOLT; LONG ${ }^{58}$, um dos problemas apresentados pelas técnicas que utilizam gutapercha termoplastificada é a dificuldade no controle do limite da obturação.

BONETTI FILHO; LEAL; MENDES ${ }^{14}$ e HOLLAND et al. ${ }^{64}$ verificaram que quando o cimento é levado ao canal radicular pela técnica clássica promove um melhor selamento apical quando comparado ao cimento levado apenas nos cones de guta-percha. No entanto, a técnica clássica apresenta como inconveniente uma maior freqüência de extravasamento de cimento para os tecidos periapicais. Em nosso estudo, houve extravasamento do cimento obturador em todos os canais radiculares, de todos os grupos, o que pode ter acontecido pelo uso da técnica clássica.

Quanto ao extravasamento da guta-percha, o sistema Ultrafil apresentou o pior resultado, pois houve extravasamento em 19 dentes (95\%), seguido pelo sistema JS Quick-Fill, 4 dentes (20\%), System B e Microseal, 1 dente (5\%) e condensação lateral, a qual não mostrou nenhum extravasamento de gutapercha.

Apesar de os sistemas Microseal e System B utilizarem gutapercha termoplastificada, apresentaram pequena porcentagem de extravasamento da mesma durante a obturação dos canais radiculares. Isso ocorreu provavelmente 
porque esses sistemas utilizam um cone principal de guta-percha, o que possibilita um melhor controle do limite da obturação.

GULABIVALA; HOLT; LONG ${ }^{58}$ relataram que canais obturados pela técnica da condensação lateral apresentaram melhor controle do limite da obturação que os obturados pelo sistema JS Quick-Fill, corroborando os resultados encontrados em nosso trabalho.

O melhor controle do limite da obturação proporcionado pela técnica da condensação lateral, quando comparada ao sistema Ultrafil, também foi demonstrado na literatura por AMDITIS et al. ${ }^{4}$, BUDD; WELLER; KULILD ${ }^{24}$, LACOMBE et al. ${ }^{83}$ e SOARES; ROCHA ${ }^{132}$. Devido ao alto índice de extravasamento proporcionado pelo sistema Ultrafil, tem sido sugerida a confecção de um "plug" de dentina ou de hidróxido de cálcio ${ }^{58,126}$ para evitar esse inconveniente. Outra opção, segundo o fabricante ${ }^{143}$, seria a utilização de um cone principal de guta-percha associado à guta-percha injetável.

Neste estudo, não se observou relação entre a infiltração apical dos canais radiculares e o extravasamento de guta-percha apresentada pelas diferentes técnicas avaliadas.

Embora a temperatura gerada pelas técnicas de obturação que utilizam guta-percha termoplastificada não tenha sido o objeto deste trabalho, julgamos importante tecer algumas considerações a esse respeito.

Com as novas técnicas de obturação dos canais radiculares, o emprego de instrumentos aquecidos no interior do canal radicular tornou-se freqüente. Dessa forma, despertou-se na literatura um interesse sobre os efeitos nocivos do calor aos tecidos de suporte do dente durante a obturação do canal radicular $^{94,129}$. Embora a dentina e a guta percha ${ }^{53,86,136}$ sejam pobres condutoras térmicas e o cimento obturador aja como um isolante ${ }^{86,136}$, o calor localizado no interior do canal pode se irradiar parcialmente para a superfície externa da raiz ${ }^{94,136}$.

Antigamente, pouco se sabia sobre a temperatura crítica que poderia causar danos reversíveis e irreversíveis ao tecido ósseo. Tendo como base o trabalho de ERIKSSON; ALBREKTSSON ${ }^{37}$, estabeleceu-se que a elevação da temperatura na superfície externa da raiz, acima de $10^{\circ} \mathrm{C}$ da temperatura corporal, pode causar danos aos tecidos de suporte do dente ${ }^{12,37,42,86,94,120,129,136}$, sendo 
esse aumento considerado o nível crítico. Sabe-se, também, que quanto maior for o tempo de aplicação do calor, maiores poderão ser os danos causados aos tecidos de suporte ${ }^{37,42}$.

Os resultados de diversos trabalhos "in vitro" $86,120,129,136$ indicam que o System B é um aparelho seguro pois promove elevação da superfície externa do dente abaixo de nível crítico, ou seja, menor que $10^{\circ} \mathrm{C}$ da temperatura corporal, provavelmente não causando danos aos tecidos de suporte. "In vivo", a elevação da temperatura na superfície externa da raiz pode ser ainda menor pela presença do fluido nos túbulos dentinários, ligamento periodontal e sistema vascular perirradicular ${ }^{129}$, que podem ajudar a dissipar o calor ${ }^{86}$.

Nos sistemas JS Quick-Fill e Microseal, embora seja gerada uma quantidade de calor durante o atrito do instrumento com a parede do canal, não encontramos informações sobre a temperatura transmitida à superfície externa do dente durante a obturação dos canais radiculares, talvez pela introdução recente desses sistemas de obturação.

Outro fato observado neste estudo foi que não houve relação entre a aparência radiográfica da obturação dos canais radiculares e o grau de infiltração apical de corante. Esse fato também foi evidenciado por LACOMBE et al. $^{83}$, MCROBERT; LUMLEY ${ }^{95}$ e SOARES; ROCHA ${ }^{132}$. Alguns canais radiculares que apresentavam radiograficamente uma obturação densa e homogênea exibiram grande infiltração de corante, enquanto outros canais que apresentavam obturação insatisfatória demonstraram pequena infiltração de corante.

Embora a capacidade de selamento apical seja um fator de grande importância para o sucesso do tratamento dos canais radiculares, outros fatores como qualidade da obturação, custo de equipamentos, tempo gasto e, principalmente, domínio da técnica são aspectos que devem ser considerados na seleção da técnica para a obturação dos canais radiculares. 


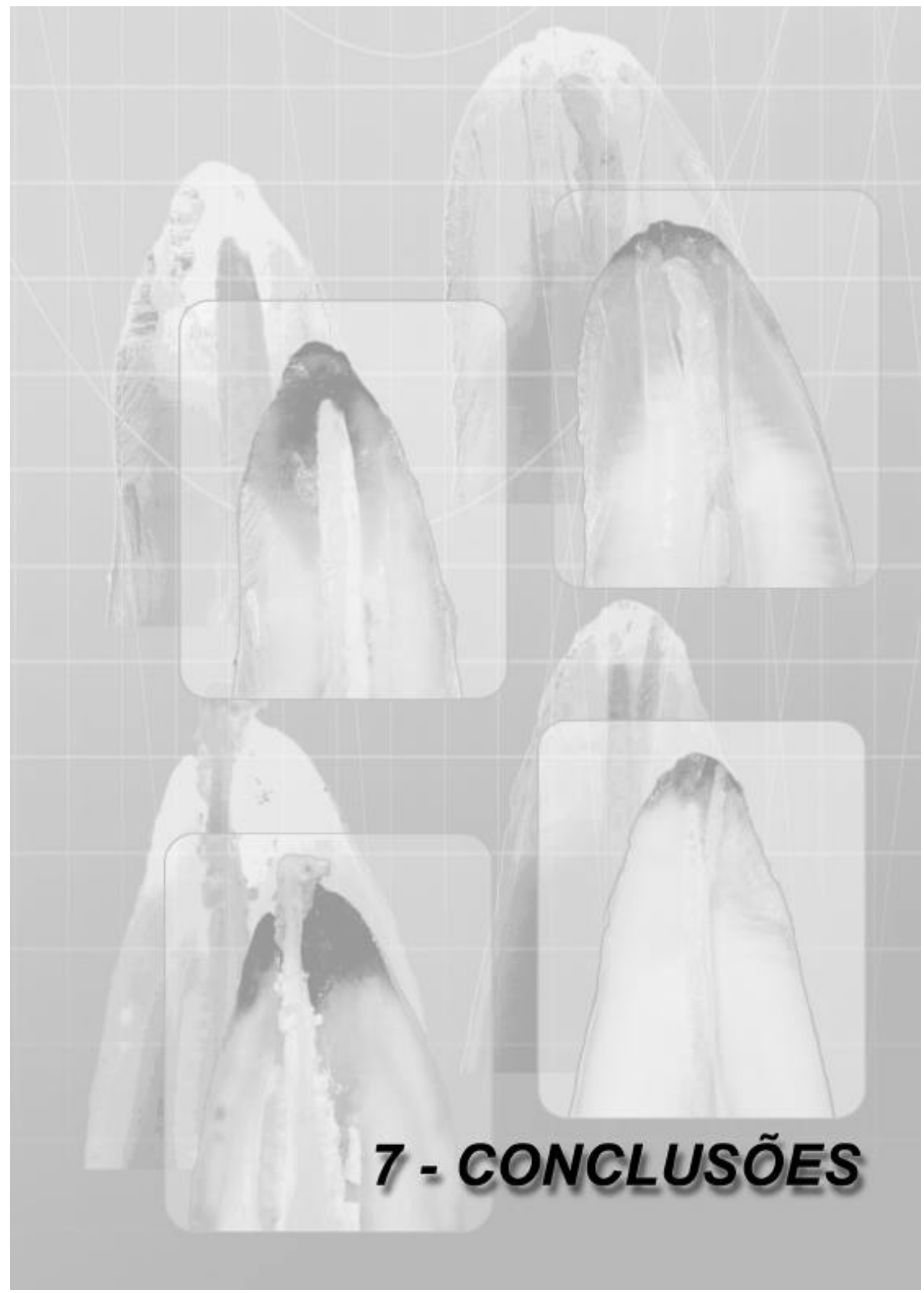




\section{7 - CONCLUSÕES}

Considerando a metodologia empregada e os resultados deste estudo, podemos concluir que:

1. Nenhuma das técnicas de obturação estudadas foi capaz de impedir a infiltração apical de corante em todos os dentes.

2. Quanto ao selamento apical dos canais radiculares, as técnicas que apresentaram do melhor para o pior selamento foram:

27 Guta-percha termoplastificada associada a um cone principal realizada com o sistema Microseal;

จู Onda Contínua de Condensação realizada com o System B;

그 Guta-percha termoplastificada mecanicamente realizada com o sistema JS Quick-Fill;

ปู Guta-percha termoplastificada injetável realizada com o sistema Ultrafil;

จู Condensação Lateral realizada com lima tipo Kerr.

3. O sistema Microseal apresentou, estatisticamente, um selamento apical semelhante ao do System B e melhor que dos demais grupos avaliados.

4. O System B apresentou, estatisticamente, um selamento apical melhor que o da técnica da Condensação Lateral e semelhante ao dos demais sistemas avaliados.

5. A técnica da Condensação Lateral e os sistemas Ultrafil e JS Quick-Fill, estatisticamente, apresentaram capacidade de selamento semelhante. 


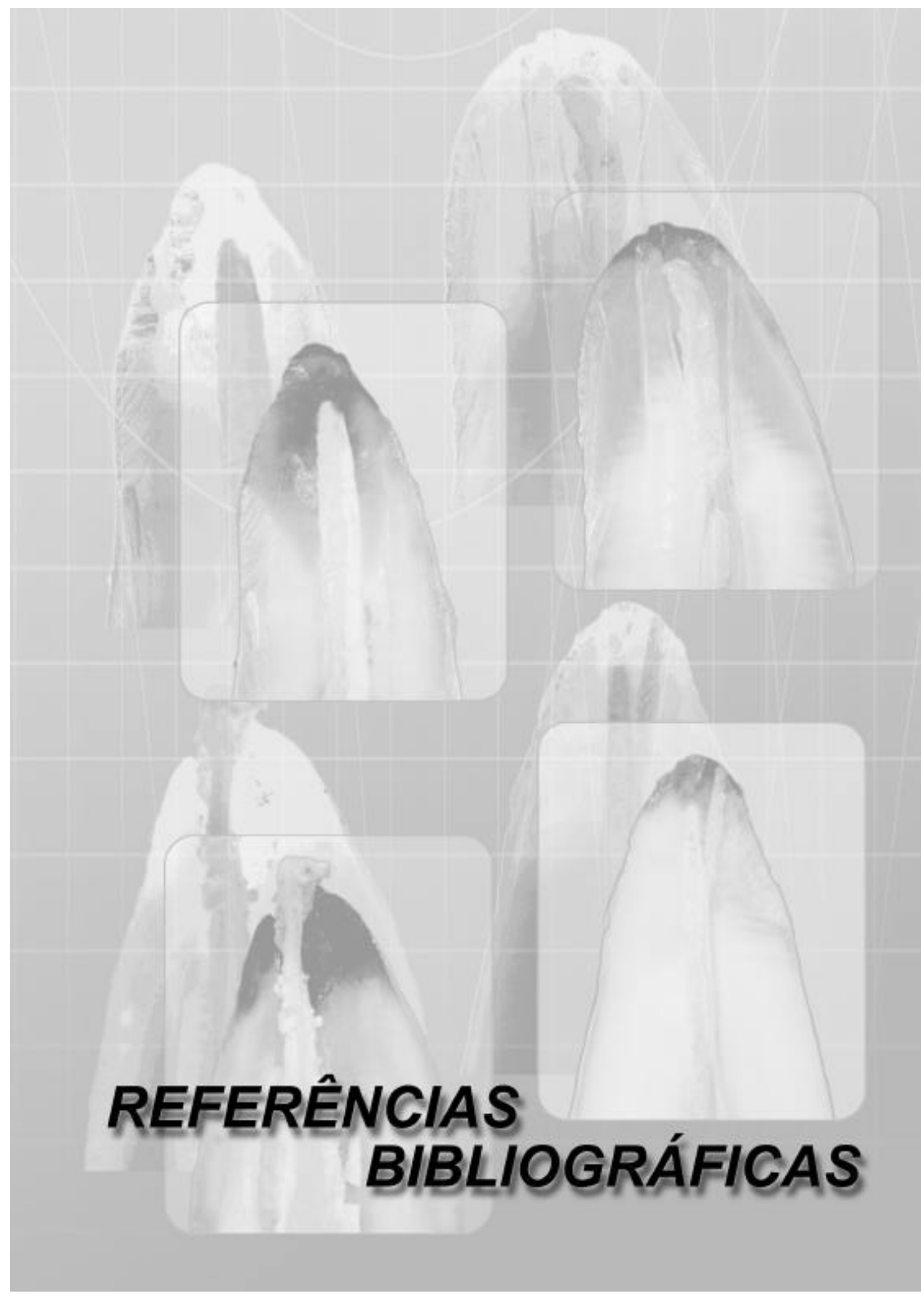




\section{REFERÊ NCIAS BIBLIOGRÁFICAS*}

1. AL-DEWANI, N.; HAYES, S.J.; DUMMER, P.M.H. Comparison of laterally condensed and low-temperature thermoplasticized gutta-percha root fillings. J. Endod., v.26, n.12, p.733-8, Dec. 2000.

2. ALLISON, D.A.; MICHELICH, R.J.; WALTON, R.E. The influence of master cone adaptation on the quality of the apical seal. J. Endod., v.7, n.2, p.61-5, Feb. 1981.

3. AMDITIS, C.; BRYANT, R.W.; BLACKLER, S.M. The assessment of apical leakage of root-filled teeth by the electrochemical technique. Aust. dent. J., v.38, n.1, p.22-7, Feb. 1993.

4. AMDITIS, C. et al. The adaptation achieved by four root canal filling techniques as assessed by three methods. Aust. dent. J., v.37, n.6, p.439-44, Dec. 1992.

5. ANTONOPOULOS, K.G.; ATTIN, T.; HELLWIG, E. Evaluation of the apical seal of root canal fillings with different methods. J. Endod., v.24, n.10, p.655-8, Oct. 1998.

6. ARTAZA, L.P. Evaluación del sellado apical obtenido por tres técnicas de obturación endodóntica con gutapercha termoplastizada. Rev. Asoc. odont. argent., v.87, n.1, p.54-9, ene./feb. 1999.

* Normas recomendadas para uso no âmbito da Universidade de São Paulo, com base no documento "Referências Bibliográficas: exemplos", emanado do Conselho Supervisor do Sistema Integrado de Bibliotecas da USP, em reunião em 20 de setembro de 1990. 
7. AZEVEDO, P.C. et al. Efeitos da instrumentação e da condensação lateral na infiltração apical em canais radiculares obturados pela técnica clássica. Rev. bras. Odont., v.44, n.4, p.18-24, jul./ago. 1987.

8. BARTHEL, C.R. et al. Bacterial leakage versus dye leakage in obturated root canals. Int. Endod. J., v.32, n.5, p.370-5, Sept.1999.

9. BEATTY, R.G. et al. The efficacy of four root canal obturation techniques in preventing apical dye penetration. J. Amer. dent. Ass., v.119, n.5, p.633-7, Nov. 1989.

10. BERBERT, A. et al. Infiltração marginal e constância do limite apical da obturação de canais radiculares, em função das técnicas de Schilder e de McSpadden, com ou sem cimento. Estomat. Cult., v.16, n.4, p.48-53, out./dez.1986.

11. BERNARDINELI, N. Obturação retrógrada: avaliação da adaptação às paredes da cavidade e infiltração marginal, em função de materiais obturadores e de agentes de limpeza. Bauru, 1993. 168p. Tese (Livre Docência) - Faculdade de Odontologia de Bauru, Universidade de São Paulo.

12. BLUM, J.Y.; PARAHY, E.; MACHTOU, P. Warm vertical compaction sequences in relation to gutta-percha temperature. J. Endod., v.23, n.5, p.307-11, May 1997.

13. BLUM, J.Y. et al. Analysis of the Endogrammes developed during obturations on extracted teeth using System B. J. Endod., v.27, n.11, p.661-5, Nov. 2001. 
14. BONETTI FILHO, I.; LEAL, J.M.; MENDES, A.J.D. Avaliação "in vitro" da capacidade seladora de diferentes técnicas de obturação dos canais radiculares através da infiltração do corante rodamina B a 0,2\%. Rev. odont. clin., v.1, n.2, p.17-21, jan./jun. 1987.

15. BONETTI FILHO, I. et al. Avaliação "in vitro" da capacidade seladora da técnica de obturação Microseal através da infiltração apical do corante azul de metileno a $\%$. Rev. bras. Odont., v.57, n.2, p.80-3, mar./abr. 2000.

16. BOWMAN, C.J.; BAUMGARTNER, J.C. Gutta-percha obturation of lateral grooves and depressions. J. Endod., v.28, n.3, p.220-3, Mar. 2002.

17. BRAITT, A.H. Condensação lateral versus técnica de McSpadden. Rev. gaúcha Odont., v.35, n.6, p.437-40, nov./dez. 1987.

18. BRAMANTE, C.M.; BERBERT, A.; PICCINO, A.C. Técnica de condensação lateral para obturações de canais radiculares de pequenos diâmetros, com cones de guta-percha. Estomat. Cult., v.6, n.1, p.70-72, jan./jun. 1972.

19. BRAMANTE, C.M. et al. Estudo comparativo de algumas técnicas de obturação de canais radiculares. Rev. bras. Odont., v.46, n.5, p.26-35, set./out. 1989.

20. BRAMANTE, C.M. et al. Anatomia das cavidades pulpares. Rio de Janeiro, Pedro Primeiro, 2000.

21. BRANDÃO, C.G. Propriedades físico-químicas dos cimentos endodônticos resinosos Sealer 26, e dos experimentais, Sealer Plus e MBP, comparadas às do óxido de zinco e eugenol. Bauru, 1999. 150p. Dissertação (Mestrado) - Faculdade de Odontologia de Bauru, Universidade de São Paulo. 
22. BUCHANAN, L.S. The continuous wave of condensation technique: a convergence of conceptual and procedural advances in obturation. Dent. Today, v.13, n.10, p.80-5, Oct. 1994.

23. BUCHANAN, L.S. The continuous wave of obturation technique: "centered" condensation of warm gutta percha in 12 seconds. Dent. Today, v.15, n.1, p. 60-7, Jan. 1996.

24. BUDD, C.S.; WELLER, R.N.; KULILD, J.C. A comparison of thermoplasticized injectable gutta-percha obturation techniques. J. Endod., v.17, n.6, p.260-4, June 1991.

25. BUNN, C.W. Molecular structure of rubber-like elasticity. Part I: The crystal structure of gutta-percha, rubber and polychloroprene. Proc $\mathbf{R}$ Soc Lond [Biol], v.80, n.40, 1942 apud MARCIANO, J.; MICHAILESCO, P.; ABADIE, M.J.M. Stereochemical structure characterization of dental gutta-percha. J. Endod., v.19, n.1, p.31-4, Jan. 1993.

26. CALLAHAN, J.R. Rosin solution of the sealing of the dentinal tubuli and as an adjuvant in the filling of root canals. J. Allied. Dent. Soc. v.9, p.53-63, 1914 apud MAZOTTI, D. Avaliação comparativa “in vitro" da capacidade de preenchimento do sistema de canais radiculares de diferentes técnicas de obturação. Araraquara, 2001.192p. Dissertação (Mestrado). Faculdade de Odontologia de Araraquara, Universidade Estadual Paulista.

27. CALLIS, P.D.; PATERSON, A.J. Microleakage of root fillings: thermoplastic injection compared with lateral condensation. J. Dent., v.16, n.4, p.194-7, Aug. 1988.

28. CANALDA-SAHLI, C.; BERÁSTEGUI-JIMENO, E.; BRAU-AGUADÉ, E. Apical sealing using two thermoplasticized gutta-percha techniques compared with lateral condensation. J. Endod., v.23, n.10, p.636-8, Oct. 1997. 
29. COHEN, S.; BURNS, R.C. Caminhos da polpa. 7 ed. Rio de Janeiro, Guanabara Koogan, 2000.

30. COMBE, E.C.; COHEN, B.D.; CUMMINGS, K. Alpha- and beta-forms of guttapercha in products for root canal filling. Int. Endod. J., v.34, n.6, p.447-51, Sept. 2001.

31. CZONSTKOWSKY, M.; MICHANOWICZ, A.; VAZQUEZ, J.A. Evaluation of an injection of thermoplasticized low-temperature gutta-percha using radioactive isotopes. J. Endod., v.11, n.2, p.71-4, Feb. 1985.

32. DALAT, D.M.; SPANGBERG, L.S.W. Comparison of apical leakage in root canals obturated with various gutta-percha techniques using a dye vacuum tracing method. J. Endod., v.20, n.7, p.315-9, July 1994.

33. DAVALOU, S.; GUTMANN, J.L.; NUNN, M.H. Assessment of apical and coronal root canal seals using contemporary endodontic obturation and restorative materials and techniques. Int. Endod. J., v.32, n.5, p.388-96, Sept. 1999.

34. DONLEY, D.L. et al. In vitro intracanal temperatures produced by low-and hightemperature thermoplasticized injectable gutta-percha. J. Endod., v.17, n.7, p.307-9, July 1991.

35. DOW, P.R.; INGLE, J. Endodontics: isotope determination of root canal failure. Oral Surg., v.8, p.1100-4, 1955.

36. DULAC, K.A. et al. Comparison of the obturation of lateral canals by six techniques. J. Endod., v.25, n.5, p.376-80, May 1999. 
37. ERIKSSON, A.R.; ALBREKTSSON, T. Temperature threshold levels for heatinduced bone tissue injury: a vital-microscopic study in the rabbit. J. prosth. Dent., v.50, n.1, p.101-7, July 1983.

38. EVANS, J.T.; SIMON, J.H.S. Evaluation of the apical seal produced by injected thermoplasticized gutta-percha in the absence of smear layer and root canal sealer. J. Endod., v.12, n.3, p.101-7, Mar. 1986.

39. EXTRAORDINARY microseal: obturação endodôntica. São Paulo, Tycom Brasil, s.d.

40. FAUCHARD, P. Le chirurgien-dentiste-traité des dents TI. 2.ed. Paris: Chez Pierre Jean Marriete, 1745, 182p. apud ESTRELA, C.; FIGUEIREDO, J.A.P. de. Endodontia: princípios biológicos e mecânicos. São Paulo, Artes Médicas, 1999.

41. FIGUEIREDO, J.A.P. de; ESTRELA, C. Obturação do canal radicular. In: ESTRELA, C.; FIGUEIREDO, J.A.P. de. Endodontia: princípios biológicos e mecânicos. São Paulo, Artes Médicas, 1999. Cap. 18, p.656-690.

42. FLOREN, J.W. et al. Changes in root surface temperatures with in vitro use of the System B heat source. J. Endod., v.25, n.9, p.593-5, Sept. 1999.

43. FRÓES, J.A.V.; HORTA, H.G.P.; SILVEIRA, A.B. da. Smear layer influence on the apical seal of four different obturation techniques. J. Endod., v.26, n.6, p.351-4, June 2000.

44. FUSS, Z. et al. Comparative sealing quality of gutta-percha following the use of the McSpadden compactor and engine plugger. J. Endod., v.11, n.3, p.11721, Mar. 1985. 
45. GENÇOGLU, N.; SAMANI, S.; GÜNDAY, M. Dentinal wall adaptation of thermoplasticized gutta-percha in the absence or presence of smear layer: a scanning electron microscopic study. J. Endod., v.19, n.11, p.558-62, Nov. 1993.

46. GENÇOGLU, N.; SAMANI, S.; GÜNDAY, M. Evaluation of sealing properties of Thermafil and Ultrafil techniques in the absence or presence of smear layer. J. Endod., v.19, n.12, p.599-603, Dec. 1993.

47. GEORGE, J.W.; MICHANOWICZ, A.E.; MICHANOWICZ, J.P. A method of canal preparation to control apical extrusion of low-temperature thermoplasticized gutta-percha. J. Endod., v.13, n.1, p.18-23, Jan. 1987.

48. GILHOOLY, R.M.P. et al. Comparison of cold lateral condensation and a warm multiphase gutta-percha technique for obturating curved root canals. Int. Endod. J., v.33, n.5, p.415-20, Sept. 2000.

49. GOLDBERG, F.; ARTAZA, L.P.; SILVIO, A. de. Effectiveness of different obturation techniques in the filling of simulated lateral canals. J. Endod., v.27, n.5, p.362-4, May 2001.

50. GOLDBERG, F. et al. Surface architecture of a low-temperature thermoplasticized gutta-percha. Endod. dent. Traumat., v.7, n.3, p.108-11, June 1991.

51. GOLDMAN, M.; SIMMONDS, S.; RUSH, R. The usefulness of dye-penetration studies reexamined. Oral Surg., v.67, n.3, p.327-32, Mar. 1989.

52. GOODMAN, A.; SCHILDER, H.; ALDRICH, W. The thermomechanical properties of gutta-percha: II. The history and molecular chemistry of guttapercha. Oral Surg., v.37, n.6, p.954-61, June 1974. 
53. GOODMAN, A.; SCHILDER, H.; ALDRICH, W. The thermomechanical properties of gutta-percha: Part IV. A thermal profile of the warm guttapercha packing procedure. Oral Surg., v.51, n.5, p.544-51, May 1981.

54. GOUND, T.G. et al. A description of an alternative method of lateral condensation and a comparison of the ability to obturate canals using mechanical or traditional lateral condensation. J. Endod., v.26, n.12, p.7569, Dec. 2000.

55. GRASSI, M.D. et al. Changes in the physical properties of the Ultrafil lowtemperature $\left(70^{\circ} \mathrm{C}\right)$ thermoplasticized gutta-percha system. J. Endod., v.15, n.11, p.517-21, Nov. 1989.

56. GREEN, D. A stereomicroscopic study of the root apices of 400 maxillary and mandibular anterior teeth. Oral Surg., v.9, n.11, p.1224-32, Nov. 1956.

57. GREENE, H.A.; WONG, M.; INGRAM, T.A. Comparison of the sealing ability of four obturation techniques. J. Endod., v.16, n.9, p.423-8, Sept. 1990.

58. GULABIVALA, K.; HOLT, R.; LONG, B. An in vitro comparison of thermoplasticized gutta-percha obturation techniques with cold lateral condensation. Endod. dent. Traumat., v.14, n.6, p.262-9, Dec. 1998.

59. HAÏKEL, Y. et al. A new method for the quantitative analysis of endodontic microleakage. J. Endod., v.25, n.3, p.172-7, Mar. 1999.

60. HAÏKEL, Y. et al. Apical microleakage of radiolabeled lysozyme over time in three techniques of root canal obturation. J. Endod., v.26, n.3, p.148-52, Mar. 2000.

61. HARRIS, G.Z. et al. Apical seal: McSpadden vs lateral condensation. J. Endod., v.8, n.6, p.273-6, June. 1982. 
62. HATA, G. et al. Sealing ability of thermoplasticized gutta-percha fill techniques as assessed by a new method of determining apical leakage. J. Endod., v.21, n.4, p.167-72, Apr. 1995.

63. HOLLAND, R.; MURATA, S.S.; DEZAN JUNIOR, E. Avaliação da infiltração apical e nível da obturação do canal após o emprego dos sistemas Ultrafil e Endotec. Rev. gaúcha Odont., v.45, n.5, p.291-5, set./out. 1997.

64. HOLLAND, R. et al. Avaliação da eficiência do selamento marginal de obturações de canal - influência de variáveis introduzidas no método da condensação lateral. Rev. gaúcha Odont., v.23, n.4, p.247-52, 1975.

65. HOLLAND, R. et al. Influência do emprego do vácuo na profundidade da infiltração marginal do azul de metileno em dentes com canais obturados. Rev. Ass. paul. cirurg. Dent., v.44, n.4, p.213-6, jul./ago. 1990.

66. HOLLAND, R. et al. Influência de alguns procedimentos clínicos na infiltração marginal de obturações realizadas pela técnica da condensação lateral. Rev. paul. Odont., v.13, n.4, p.29-38, jul./ago. 1991.

67. HOLLAND, R. et al. Infiltração marginal apical após a obturação de canal com três tipos diferentes de guta-percha do sistema Ultrafil. Rev. Odont. UNESP, v.24, n.1, p.39-45, jan./jun. 1995.

68. INGLE, J.I. et al. Modern endodontic therapy. In: INGLE, J.I.; BAKLAND, L.K. Endodontics. 4.ed. Baltimore, Lea \& Febiger, 1994. Cap.1, p. 1-52.

69. ISHLEY, D.J.; ELDEEB, M.E. An in vitro assessment of the quality of apical seal of thermomechanically obturated canals with and without sealer. $\mathbf{J}$. Endod., v.9, n.6, p.242-5, June 1983. 
70. JACOBSON, H.L.J. et al. Microbial leakage evaluation of the continuous wave of condensation. J. Endod., v.28, n.4, p.269-71, Apr. 2002.

71. JACOBSON, S.M.; VON FRAUNHOFER, J.A. The investigation of microleakage in root canal therapy. An electrochemical technique. Oral Surg., v.42, n.6, p.817-23, Dec. 1976.

72. JEROME, C.E. Warm vertical gutta-percha obturation: a technique update. J. Endod., v.20, n.2, p.97-9, Feb. 1994.

73. JS QUICK-FILL: instructions. Ridgefield, CT, JS Dental Manufacturing, s.d.

74. JURCAK, J.J. et al. In vitro intracanal temperatures produced during warm lateral condensation of gutta-percha. J. Endod., v.18, n.1, p.1-3, Jan. 1992.

75. KARAGÖZ-KÜÇÜKAY, I. Root canal ramifications in mandibular incisors and efficacy of low-temperature injection thermoplasticized gutta-percha filling. J. Endod., v.20, n.5, p.236-40, May 1994.

76. KARAGÖZ-KÜÇÜKAY, I.; BAYIRLI, G. An apical leakage study in the presence and absence of the smear layer. Int. Endod. J., v.27, n.2, p.87-93, Mar. 1994.

77. KARAGÖZ-KÜÇÜKAY, I.; KÜÇÜKAY, S.; BAYIRLI, G. Factors affecting apical leakage assessment. J. Endod., v.19, n.7, p.362-5, July 1993.

78. KATAIA, M.A.; EL SAYED, J. M. Comparative sealability study on root canal obturation using multiphase gutta-percha and lateral condensation technique. Egyptian dent. J., v.40, n.3, p.847-53, July 1994.

79. KERSTEN, H.W.; MOORER, W.R. Particles and molecules in endodontic leakage. Int. Endod. J., v.22, n.3, p.118-24, May 1989. 
80. KONTAKIOTIS, E.G.; GEORGOPOULOU, M.K.; MORFIS, A.S. Dye penetration in dry and water-filled gaps along root fillings. Int. Endod. J., v.34, n.2, p.133-6, Mar. 2001.

81. KORZEN, B.H. Endodontic obturation using the Microseal technique. Oral Health., v.87, n.10, p.67-73, Oct. 1997.

82. KYTRIDOU, V.; GUTMANN, J.L.; NUNN, M.H. Adaptation and sealability of two contemporary obturation techniques in the absence of the dentinal smear layer. Int. Endod. J., v.32, n.6, p.464-74, Nov. 1999.

83. LACOMBE, J.S. et al. A comparison of the apical seal produced by two thermoplasticized injectable gutta-percha techniques. J. Endod., v.14, n.9, p.445-50, Sept. 1988.

84. LAMBRIANIDIS, T. et al. Apical placement of needle tip with an injectionthermoplasticized gutta-percha technique for root canal obturation. Endod. dent. Traumat., v.6, n.2, p.56-9, Apr. 1990.

85. LEE, C.Q. et al. Dimensional stability of thermosensitive gutta-percha. J. Endod., v.23, n.9, p.579-82, Sept. 1997.

86. LEE, F.S.; VAN CURA, J.E.; BEGOLE, E. A comparison of root surface temperatures using different obturation heat sources. J. Endod., v.24, n.9, p.617-20, Sept. 1998.

87. LEONARDO, M.R.; LEAL, J.M. Endodontia: tratamento de canais radiculares. 3.ed. São Paulo, Panamericana, 1998.

88. LIFSHITZ, J; SCHILDER, H.; PAMEIJER, C.H. Scanning electron microscope study of the warm gutta-percha technique. J. Endod., v.9, n.1, p.17-24, Jan. 1983. 
89. LYROUDIA, K. et al. Three-dimensional reconstruction: a new method for the evaluation of apical microleakage. J. Endod., v.26, n.1, p.36-8, Jan. 2000.

90. MARCIANO, J.; MICHAILESCO, P.; ABADIE, M.J.M. Stereochemical structure characterization of dental gutta-percha. J. Endod., v.19, n.1, p.31-4, Jan. 1993.

91. MASTERS, J.; HIGA, R.; TORABINEJAD, M. Effects of vacuuming on dye penetration patterns in root canals and glass tubes. J. Endod., v.21, n.6, p.332-4, June 1995.

92. MATLOFF, I.R. et al. A comparison of methods used in root canal sealability studies. Oral Surg., v.53, n.2, p.203-8, Feb. 1982.

93. MAZOTTI, D. Avaliação comparativa "in vitro" da capacidade de preenchimento do sistema de canais radiculares de diferentes técnicas de obturação. Araraquara, 2001.192p. Dissertação (Mestrado) Faculdade de Odontologia de Araraquara, Universidade Estadual Paulista.

94. MC CULLAGH, J.J.P. et al. A comparison of thermocouple and infrared thermographic analysis of temperature rise on the root surface during the continuous wave of condensation technique. Int. Endod. J., v.33, n.4, p.326-32, July 2000.

95. MCROBERT, A.S.; LUMLEY, P.J. An in vitro investigation of coronal leakage with three gutta-percha backfilling techniques. Int. Endod. J., v.30, n.6, p.413-7, Nov. 1997.

96. MCSPADDEN, J. Multiphase gutta-percha technique. Dent. Economics, v.83, n.9, p.95-7, Sept. 1993. 
97. MICHANOWICZ, A.; CZONSTKOWSKY, M. Sealing properties of an injectionthermoplasticized low-temperature $\left(70^{\circ} \mathrm{C}\right)$ gutta-percha: a preliminary study. J. Endod., v.10, n.12, p.563-6, Dec. 1984.

98. MICHANOWICZ, A.E.; CZONSTKOWSKY, M.; PIESCO, N.P. Lowtemperature $\left(70^{\circ} \mathrm{C}\right)$ injection gutta-percha: a scanning electron microscopic investigation. J. Endod., v.12, n.2, p.64-7, Feb. 1986.

99. MICHANOWICZ, A.E. et al. Clinical evaluation of low-temperature thermoplasticized injectable gutta-percha: a preliminary report. J. Endod., v.15, n.12, p.602-7, Dec. 1989.

100. MORAES, I.G. Infiltração marginal nas obturações de canais radiculares em função de agentes irrigadores e cimentos obturadores. Bauru, 1981. 114p. Dissertação (Mestrado) - Faculdade de Odontologia de Bauru, Universidade de São Paulo.

101. MORAES, I.G. Propriedades físicas de cimentos epóxicos experimentais para obturação de canais radiculares, baseados no AH26. Bauru, 1984. 150p. Tese (Doutorado) - Faculdade de Odontologia de Bauru, Universidade de São Paulo.

102. MORAES, S.H.; HOLLANDA, E.M. de. Condensação lateral em Endodontia: avaliação da infiltração marginal nas técnicas passiva e ativa. Rev. gaúcha Odont., v.33, n.3, p.206-8, jul./set. 1985.

103. MOURA, A.A.M. de et al. Quality analysis of the root canal filling employing gutta-percha thermoplasticized at a low temperature (Ultrafil system). Rev. Fac. Odont. F.Z.L., v.1, n.2, p.75-82, jul./dez. 1989. 
104. NELSON, E.A.; LIEWEHR, F.R.; WEST, L.A. Increased density of gutta-percha using a controlled heat instrument with lateral condensation. J. Endod., v.26, n.12, p.748-50, Dec. 2000.

105. NUNES, E. Influência do hidróxido de cálcio e do EDTA na marcação da infiltração marginal de azul de metileno em obturação de canais radiculares. Bauru, 1999. 126p. Tese (Doutorado) - Faculdade de Odontologia de Bauru, Universidade de São Paulo.

106. OLIVER, C.M.; ABBOTT, P.V. Entrapped air and its effects on dye penetration of voids. Endod. dent. Traumat., v.7, n.3, p.135-8, June 1991.

107. OLIVER, C.M.; ABBOTT, P.V. Correlation between clinical success and apical dye penetration. Int. Endod. J., v.34, n.8, p.637-44, Dec. 2001.

108. OLSON, A.K.; HARTWELL, G.R.; WELLER, R.N. Evaluation of the controlled placement of injected thermoplasticized gutta-percha. J. Endod., v.15, n.7, p.306-9, July 1989.

109. OTANI, A.Y.; MOURA, A.A.M. de; BARBOSA, J. Contribuição para o estudo da reação inflamatória do tecido periapical em dentes de cães com canais radiculares obturados segundo as técnicas convencional e sistema Ultrafil. Rev. Inst. Cienc. Saúde, v.15, p.31-6, mar. 1997. Número especial.

110. PALLARÉS, A.; FAUS, V. A comparative study of the sealing ability of two root canal obturation techniques. J. Endod., v.21, n.9, p.449-50, Sept. 1995.

111. PALLARÉS, A.; FAUS, V.; GLICKMAN, G.N. The adaptation of mechanically softened gutta-percha to the canal walls in the presence or absence of smear layer: a scanning electron microscopic study. Int. Endod. J., v.28, n.5, p.266-9, Sept. 1995. 
112. PERRONE, R. et al. Obturación de conductos radiculares por medio de la inyección de gutapercha termoplastizada $\left(70^{\circ} \mathrm{C}\right)$ : um estudio con microscopía electrónica de barrido. Rev. Asoc. odont. argent., v.83, n.4, p.290-4, oct./dic. 1995.

113. POMMEL, L.; CAMPS, J. Effects of pressure and measurement time on the fluid filtration method in Endodontics. J. Endod., v.27, n.4, p.256-8, Apr. 2001

114. POMMEL, L.; CAMPS, J. In vitro apical leakage of System B compared with other filling techniques. J. Endod., v.27, n.7, p.449-51, July 2001.

115. POMMEL, L.; JACQUOT, B.; CAMPS, J. Lack of correlation among three methods for evaluation of apical leakage. J. Endod., v.27, n.5, p.347-50, May 2001.

116. RAMOS, C.A.S; BRAMANTE, C.M. Endodontia: fundamentos biológicos e clínicos. 2 ed. São Paulo, Santos, 2001.

117. READER, C.M. et al. Effect of three obturation techniques on the filling of lateral canals and the main canal. J. Endod., v.19, n.8, p.404-8, Aug. 1993.

118. REZENDE, C.B. de; BOMBANA; A.C. Avaliação "in vitro" da capacidade de selamento marginal apical de uma técnica de obturação empregando gutapercha termoplastificada associada ou não a cimento endodôntico. R.P.G.Rev. pós-grad (São Paulo), v.6, n.2, p.132-8, abr./jun. 1999.

119. RODA, R.S.; GUTMANN, J.L. Reliability of reduced air pressure methods used to assess the apical seal. Int. Endod. J., v.28, n.3, p.154-62, May 1995. 
120. ROMERO, A.D.; GREEN, D.B.; WUCHERPFENNIG, A.L. Heat transfer to the periodontal ligament during root obturation procedures using an in vitro model. J. Endod., v.28, n.2, p.85-7, Feb. 2000.

121. SANTA CECÍLIA, M. Selamento apical propiciado pela técnica Thermafil, em canais retos e curvos, avaliado por duas metodologias distintas. Bauru, 1994. 125p. Dissertação (Mestrado) - Faculdade de Odontologia de Bauru, Universidade de São Paulo.

122. SAUNDERS, E.M.; SAUNDERS, W.P. Long-term coronal leakage of JS Quickfill root fillings with Sealapex and Apexit sealers. Endod. dent. Traumat., v.11, n.4, p.181-5, Aug. 1995.

123. SCHILDER, H. Filling root canals in three dimensions. Dent. Clin. N. Amer., v.11, p.723-44, Nov. 1967.

124. SCHILDER, H.; GOODMAN, A.; ALDRICH, W. The thermomechanical properties of gutta-percha: I. The compressibility of gutta-percha. Oral Surg., v.37, n.6, p.946-53, June 1974.

125. SCHILDER, H.; GOODMAN, A.; ALDRICH, W. The thermomechanical properties of gutta-percha: III. Determination of phase transition temperatures for gutta-percha. Oral Surg., v.38, n.1, p.109-14, July 1974.

126. SCOTT, A.C.; VIRE, D.E. An evaluation of the ability of a dentin plug to control extrusion of thermoplasticized gutta-percha. J. Endod., v.18, n.2, p.52-7, Feb. 1992.

127. SHAKESPEARE, R.C.; DONNELLY, J.C. An in vitro comparison of apical microleakage after obturation with JS Quick-Fill or lateral condensation. J. Endod., v.23, n.5, p.312-4, May 1997. 
128. SILVA NETO, U.X. da et al. Selamento apical com as técnicas de Tagger e System B. Rev. FOB., v.9, n.3/4, p.145-9, jul./dez. 2001.

129. SILVER, G.K.; LOVE, R.M.; PURTON, D.G. Comparison of two vertical condensation obturation techniques: Touch'n heat modified and System B. Int. Endod. J., v.32, n.4, p.287-95, Aug. 1999.

130. SMITH, R.S. et al. Effect of varying the depth of heat application on the adaptability of gutta-percha during warm vertical compaction. J. Endod., v.26, n.11, p.668-72, Nov. 2000.

131. SOARES, I.J.; GOLDBERG, F. Obturação do canal radicular. In: SOARES, I.J.; GOLDBERG, F. Endodontia: técnica e fundamentos. Porto Alegre, Artmed, 2001. Cap.9, p.171-99.

132. SOARES, I.J.; ROCHA, M.J. de C. Avaliação do selamento apical de obturações radiculares realizadas com guta-percha termoplastificada através do sistema Ultrafil. Rev. bras. Odont., v.50, n.2, p.19-25, mar./abr. 1993.

133. SOUSA, M.C. de. Avaliação "in vitro" da infiltração marginal em obturações de canais radiculares, em função de agentes marcadores, tempo de imersão nestes e tipos de cimentos obturadores. Bauru, 1991. 97p. Dissertação (Mestrado) - Faculdade de Odontologia de Bauru, Universidade de São Paulo.

134. SPANGBERG, L.S.W.; ACIERNO, T.G.; CHA, B.Y. Influence of entrapped air on the accuracy of leakage studies using dye penetration methods. $J$. Endod., v.15, n.11, p.548-51, Nov. 1989.

135. STOCK, C.J.R. et al. Colour atlas and text of Endodontics. 2. ed. London, Mosby-Wolfe, 1995. 
136. SWEATMAN, T.L.; BAUMGARTNER, J.C.; SAKAGUCHI, R.L. Radicular temperatures associated with thermoplasticized gutta-percha. J. Endod., v.27, n.8, p.512-5, Aug. 2001.

137. SYSTEM B. Orange, CA, Analytic Sybron Dental Specialties, s.d.

138. TAGGER, M. et al. An improved method of three-dimensional study of apical leakage. Quintessence Int., v.14, n.10, p.981-6, Oct. 1983.

139. TAMSE, A. KATZ, A.; KABLAN, F. Comparison of apical leakage shown by four different dyes with two evaluating methods. Int. Endod. J., v.31, n.5, p.3337, Sept. 1998.

140. TAYLOR, M.J.; LYNCH, E. Microleakage. J. Dent., v.20, n.1, p.3-10, Feb. 1992.

141. TIMPAWAT, S.; VONGSAVAN, N.; MESSER, H.H. Effect of removal of the smear layer on apical microleakage. J. Endod., v.27, n.5, p.351-3, May 2001.

142. TORABINEJAD, M. et al. Scanning electron microscopic study of root canal obturation using thermoplasticized gutta-percha. J. Endod., v.4, n.8, p.24550, Aug. 1978.

143. ULTRAFIL 3D - Three-dimensional injectable gutta-percha system: instructions. Mahwah, NI, Hygenic/Coltene Whaledent, s.d.

144. VEIS, A. et al. Sealing ability of sectional injection thermoplasticized guttapercha technique with varying distance between needle tip and apical foramen. Endod. dent. Traumat., v.8, n.2, p.63-6, Apr. 1992. 
145. WALTON, R.E.; TORABINEJAD, M. Principios e prática em endodontia. 2.ed. São Paulo, Santos, 1997.

146. WEATHERS JUNIOR, A.K. "Alpha" gutta-percha - is it just another phase? Dent. Today, v.10, n.5, p.55-6, June/July 1991.

147. WEINE, F.S. Preenchimento do canal com materiais semi-sólidos.In: WEINE, F.S. Tratamento endodôntico. 5.ed. São Paulo, Santos, 1998. Cap.9, p.423-77.

148. WOLCOTT, J.F.; HIMEL, V.T.; HICKS, M.L. Thermafil retreatment using a new "System B" technique or a solvent. J. Endod., v.25, n.11, p.761-4, Nov. 1999.

149. WU, M.K.; WESSELINK, P.R. Endodontic leakage studies reconsidered. Part I. Methodology. Int. Endod. J., v.26, n.1, p.37-43, Jan.1993.

150. WU, M.; GEE, A.J. de; WESSELINK, P.R. Leakage of AH26 and Ketac-Endo used with injected warm gutta-percha. J. Endod., v.23, n.5, p.331-4, May 1997.

151. WU, M.K. et al. Fluid transport and bacterial penetration along root canal fillings. Int. Endod. J., v.26, n.4, p.203-8, July 1993.

152. YEE, F.S. et al. Three-dimensional obturation of the root canal using injectionmolded, thermoplasticized dental gutta-percha. J. Endod., v.3, n.5, p.16874, May 1977.

153. ZUOLO, M.L. et al. Infiltração marginal - Comparação entre Ultrafil e condensação lateral. Rev. Ass. paul. cirurg. Dent., v.42, n.4, p.263-5, jul./ago. 1988. 


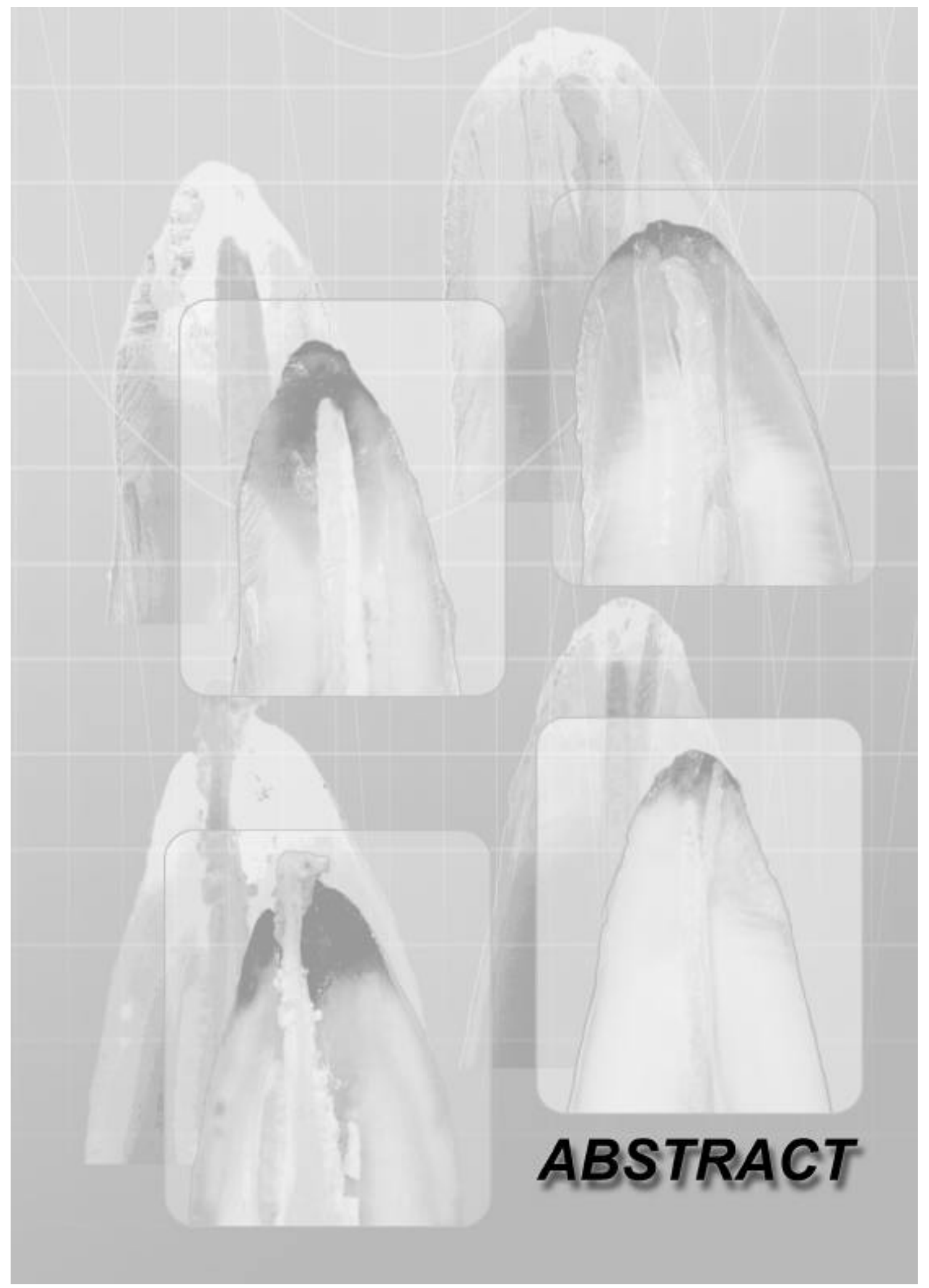




\section{AB STR ACT \\ "In vitro" evaluation of the apical sealing of root canals obturated with different techniques}

The purpose of this study was to compare the apical sealing of root canals obturated with different techniques. One hundred-six human mandibular incisors were submitted to instrumentation by means of the step-back technique. After instrumentation, one hundred teeth received an impermeable coating on the external surfaces of the crown and root (except for the area nearby the apical foramen) with one layer of araldite and two layers of nail polish. Afterwards, they were divided in five groups containing twenty elements each, according to the obturation technique employed: 1 . lateral condensation with Kerr file; 2. continuous wave of condensation technique with System B; 3. thermoplasticized injectable gutta-percha technique with the Ultrafil system; 4. mechanically thermoplasticized gutta-percha with the JS Quick-Fill system and 5. thermoplasticized gutta-percha associated to a master cone with the Microseal system. The six remaining teeth were employed as negative and positive controls. After obturation, the access cavities were sealed and the teeth were immersed in aqueous $2 \%$ methylene blue dye for 72 hours at $37^{\circ} \mathrm{C}$. After that, the teeth were longitudinally sectioned and the apical leakage was evaluated in a stereomicroscope. The Microseal system presented the best apical sealing ability, followed by System B, JS Quick-Fill, Ultrafil and the lateral condensation technique. The statistical analysis of the results demonstrated that: 1. the Microseal system presented an apical sealing similar to System B and better than the other groups; 2. System B presented better apical sealing than the lateral condensation technique, being similar to the other groups; and 3. the lateral condensation, Ultrafil and JS Quick-Fill groups demonstrated similar sealing ability. 